\begin{tabular}{l|l}
\hline 2. To: (Receiving Organization) & $\begin{array}{l}\text { 3. From: (OFiginating Organization) } \\
\text { L. F. Perkins, 222-S }\end{array}$ \\
$\begin{array}{ll}\text { Daboratories } & \text { Safety \& Health }\end{array}$ \\
$\begin{array}{ll}\text { 5. Proj./Prog./Dept./Div.: } & \text { 6. Design Authority/ Design Agent/Cog. } \\
\text { Hanford Analytical Services } & \text { D. S.: Penfield }\end{array}$
\end{tabular}

8. Originator Remarks:

Industrial Hygiene, Baseline, Laboratory Monitoring, 222-S

11. Receiver Remarks: 11A. Design Baseline Document? [] Yes [X] No For review and approval.
4. Related EDT No.:

None

7. Purchase Order No.:

MGK-SVV- 186918

9. Equip./Component No.:

Not Applicable

10. System/Bldg./Facility:

222-S Laboratory Complex

12. Major Assm. Dwg. No.:

None

13. Permit/Permit Application No.: Not Applicable

14. Required Response Date:

February 7, 1997

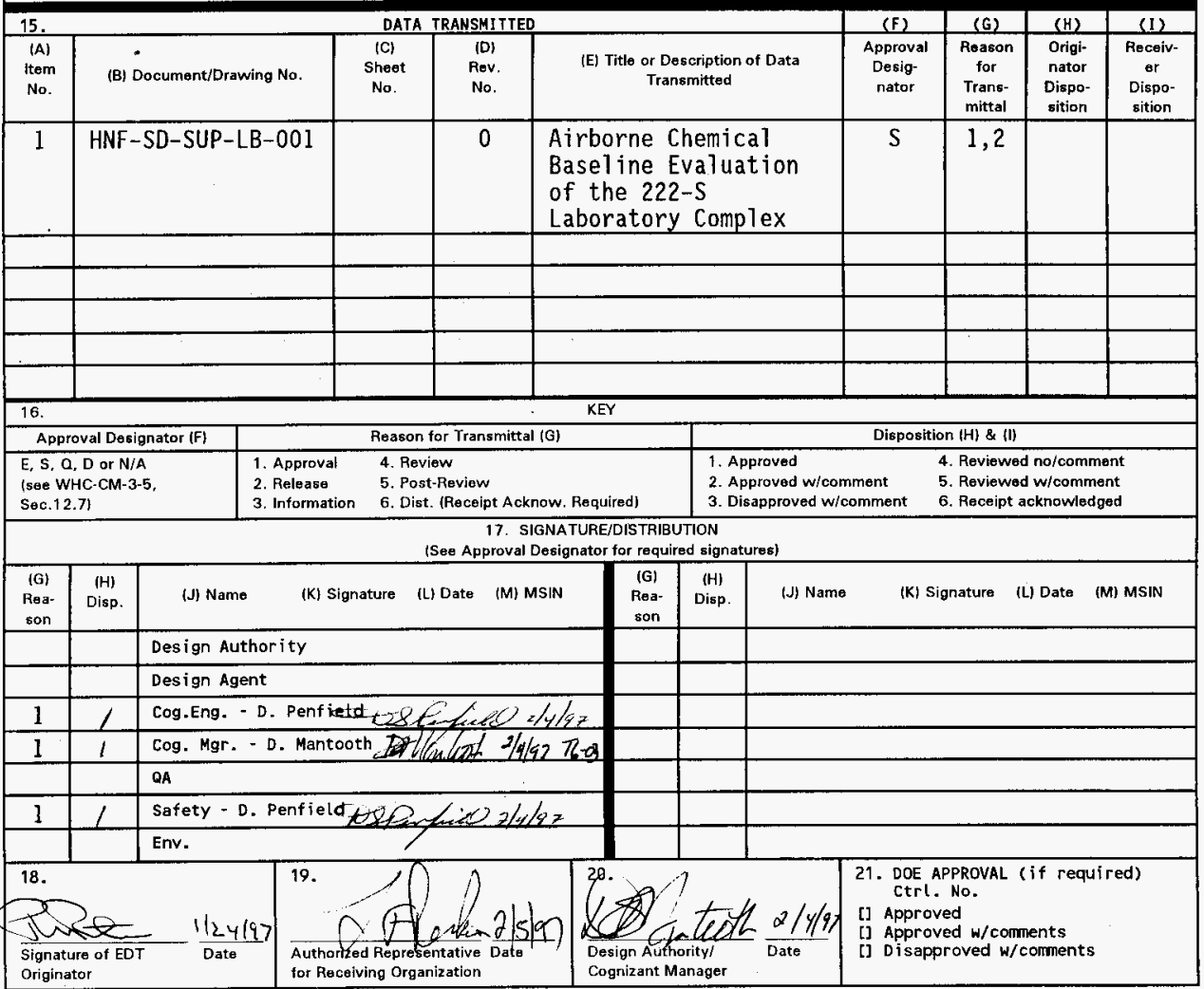

BD-7400-172-2 (05/96) GEF097 
BLOCK IITLE

\section{(3) EDT}

(2) To: (Rocoiving Organization)

(3) From: 1Originating Organization)

(4) Related EDT No.

$(5)^{*} \quad$ Proj./Prog./Dopt./Div.

(6)* Design Authority tfor Design Baseline Documente)/Cognizant Engineer (for atl Dtheral/Design Agent

(7) Purchase Order No.

(8) * Originator Remerk:

(9) Equipment/Component No.

(10) Syetem/Bddg./Facility

(11) Recoiver Remarks

(11A)* Design Bseoline Document

(12) Major Asesm. Dwe. No.

(13) Permit/Permit Application No

(14) Required Response Dato

(15) * Dato Trensmittod

(A)* Item Number

(B) * Document/Drawing No

(C) * Shoet No

(D) * Rev. No.

(E) Title or Description of Dats Transmittod

(F). Approval Designator

(G) Rosson for Transmitta

(H) Originator Disposition

(I) Receiver Disposition

(16) Koy

(17) Signature/Distribution
(G) Reabon
(H) Disposition
(J) Name
(K) * Signature
(L)* Date
(M)* MSIN

(18) Signature of EDT Originator

(19) Authorized Representative for Receiving Organization

(20) * Design Authority/Cognizant Manager

(21)*

DOE Approval
- Pre-assigned EDT number.

- Enter the individual's name, title of the organizetion, or entity le.g., Dietribution] that the EDT is being transmitted to.

- Enter the title of the organization originating and tranemitting the EDT.

- Enter EDT numbere which relete to the -dets being tranemitted.

- Enter the Project/Program/Department/Division thte or Project/Program acronym or Project Number, Work Order Number or Omenization Code.

- Enter the name of the individual identified as being responsible for coordinating disposition of the EDT.

- Enter related Purchase Order (P.0.) Number, If available.

- Enter epecial or additional commente conceming tranemittal, or "Kev" retrieval worde may be entered.

- Enter equipment/component number of affocted item, if appropriato.

- Enter applicable eyetem, building or facility number, if appropriate.

- Enter epecial or additional comments conceming tranemittal.

- Enter an " $X$ " in the appropriate box. Consult with Desion Authority for identification of Design Beseline Documente, it required.

- Enter applicable drawing numbar of major assombly, if sppropriata.

- Enter applicable permit or permit application number, if appropriate

- Enter the date a response is required from individuals identified in Block 17 (Signature/Distribution).

- Enter sequentiel number, beginning with 1, of the information listed on EDT.

- Enter the unique identification number assigned to the document or drawing being transmirted.

- Entor the shoet number of the information being transmittod. If no shoet number, lesve blank.

- Entor the revision number of the information boing tranemitted. If no revision number, leave blank.

- Enter the title of the document or drowing or a briaf description of the subject if no title is identified.

- Enter the appropriate Approval Designator (Block 15). Aleo, indicate the appropriate approvals for each item listed, i.e., SO. ESO. etc.

- Enter the appropriate codo to idontify the pupose of the data transmittal (aoe Block 16).

- Enter the appropriate disposition code (soo Block 16).

- Enter the appropriate disposition code (see Block 16 ).

- Number codes used in completion of Blocke 15 (G), (H), and (I), and 17 (G). (H) (Signature/Distribution)

- Enter the code of the reason for transmittal (Black 16).

- Enter the code for the disposition (Block 16).

- Enter the signature of the individual completing the Disposition $17(\mathrm{H})$ and the Transmittal.

- Obtain appropriote signature(s).

- Enter date signature is obtained.

- Enter MSIN. Nate: if Distribution Sheet is used, ahow entire diatribution finchuding that indicated on Page 1 of the EDT) on the Dintribution shost.

- Enter the signature and date of the individual originatine the EDT leritered prior to tranemittal to Receiving Organization). If the EDT originator is the Design Authorfy (for Design Basedine Documente)/Cognizant Enginear (for all others) or Desian Agent, sian both Blocks 17 and 18.

- Enter the signature and dete of the individual identified by the Receiving Organization Design Authortty ifor Desion Baseline Document=)/Cognizent Engineer (for all others) as authorized to approve dieposition of the EDT and accoptence of the date trensmitted, es applicable.

- Enter the signature and dete of the Design Authority/Cognizant Manager. (This signature is authorization for release.

- Enter DOE approval (if required) by signature or control number that tracks the approval to a signature, and indicate DOE action. 


\section{Airborne Chemical Baseline Evaluation of the 222- S Laboratory Complex}

Bartley, Phil ip L; Hartman, Allison J; Peters, Brian B;

Foster Wheeler Environmental Corporation, Richland, WA 99352

U.S. Department of Energy Contract DE-ACO6-87RL10930

EDT/ECN: 620717 UC: UC-2020

Org Code: 31114 Charge Code: J31HA

B\&R Code: YN0100000 Total Pages: 139

Key Words: Industrial Hygiene, Baseline, Laboratory Monitoring, 222-S

Abstract: An evaluation of the potential for elevated laboratory airborne chemical concentrations in the 222-S Laboratory Complex was performed. This evaluation was part of a comprehensive baseline evaluation of the 222-S Laboratory Complex, and was designed to determine airborne chemical monitoring requirements in accordance with the Chemical Hygiene Plan and OSHA 29 CFR 1910.1450. Elements of this evaluation included summarizing past monitoring data, performing task specific evaluations, reviewing chemical inventories, developing and utilizing airborne chemical generation and distribution models, and providing monitoring and activity recomendations.

IRADEMARK DISCLAIMER. Reference herein to any specific comercial product, process, or service by trade name, trademark, manufacturer, or otherwise, does not necessarily constitute or imply its endorsement, recommendation, or favoring by the United States Government or any agency thereof or its contractors or subcontractors.

Printed in the United States of America. To obtain copies of this document, contact: WHC/BCS Document Control Services, P.O. Box 1970, Mailstop H6-08, Richland WA 99352, Phone (509) 372-2420; Fax (509) 376-4989.
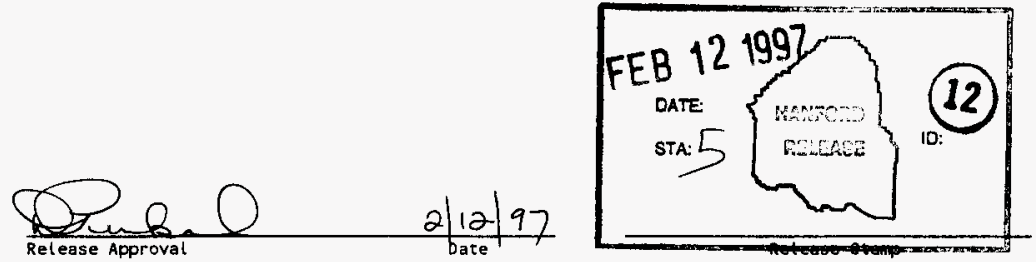

Approved for Public Release 
THIS PAGE INTENTIONALLY LEFT BLANK 


\title{
Airborne Chemical Baseline Evaluation of the 222-S Laboratory Complex
}

\author{
HNF-SD-SUP-LB-001 \\ Rev. 0 \\ January 22, 1997 \\ Prepared by \\ P.L. Bartley, CIH \\ A.J. Hartman \\ B.B. Peters, PE \\ Foster Wheeler Environmental Corporation \\ Prepared for \\ Rust Federal Services of Hanford, Inc. \\ Task 023 of Order No. MGK-SWV-186918 \\ with Lockheed Martin Hanford Corp.
}


HNF-SD-SUP-LB-001, Rev. 0

This page intentionally left blank. 


\section{PREFACE}

This document was written during the period that the operating contract for the Hanford Site was awarded to Flour Daniel Hanford, Inc. with Rust Federal Services of Hanford, Inc. assuming control of the 222-S Laboratories, while many of the general health and safety functions are being controlled by Lockheed Mart in Hanford Corp. As a result of this change, a11 of the manual names and numbers are in the process of changing. In that these changes are not complete, and additional changes are likely, the Westinghouse Hanford Company manual and document names and numbers have been retained for this document. 
HNF-SD-SUP-LB-001, Rev. 0

This page intentionally left blank. 


\section{EXECUTIVE SUMMARY}

The 222-s Laboratory complex stores and uses over 400 chemicals. Many of these chemicals are used in laboratory analysis and some are used for maintenance activities. The majority of laboratory analysis chemicals are only used inside of fume hoods or glove boxes to control both chemical and radionuclide airborne concentrations.

This evaluation was designed to determine the potential for laboratory analysis chemicals at the 222-S Laboratory complex to cause elevated airborne chemical concentrations under normal conditions. This was done to identify conditions and activities that should be subject to airborne chemical monitoring in accordance with the Westinghouse Hanford Company Chemical Hygiene Plan.

To identify conditions associated with potential elevated airborne concentrations, work areas were inspected, ventilation and storage conditions were evaluated, and past and current monitoring activities were reviewed. In addition, chemicals of concern were identified and models were developed to predict airborne concentrations.

Airborne chemical monitoring has been performed in the past at the 222-S Laboratory complex. Chemicals monitored included methylene chloride and 1,2,4-trimethyl benzene, the primary material in Insta-Gel (Insta-Gel is a trademark of Packard Instruments).

Since 1989, monitoring has been performed for 57 laboratory chemicals. None were greater than airborne 1 imits and 27 were less than detectable 
HNF-SD-SUP-LB-001, Rev. 0

concentrations. The highest airborne concentration monitoring results were for methylene chloride use outside of the hood.

Conditions with potential elevated concentrations were initially identified in room $4 \mathrm{~L}$ when opening flammable material storage cabinets, room 2B during decontamination, in the 222-SA Standards Laboratory while weighing solids, and during general activities performed outside of hoods. A mercury distillation unit was also present in room $4 \mathrm{~L}$, that was previously in room $4 \mathrm{E}$, that could result in elevated levels but was not evaluated because the system is reportedly not currently operational.

Chemicals of concern were chosen for evaluation based on activity performed and usage frequency. Airborne chemical concentrations were estimated based on activity, predicted contaminate generation rate, and predicted airborne distribution using models from the EPA and nationally recognized organizations.

\section{Storage Cabinets}

There are many chemicals in the cabinets evaluated in room 4L. Xylene and methylene chloride were used for modeling. The models indicated that exposures when opening the $f 1$ ammable storage cabinets in room $4 \mathrm{~L}$ could temporarity be high but would not likely result in exceeding airborne limits. Recommended actions for these cabinets include: 1) better characterize the contents, 2) monitor the air upon opening the cabinet to demonstrate compliance, and 3 ) annually repeat the monitoring while chemicals remain in the cabinet. 
Removing the material will eliminate all exposure. If monitoring indicates elevated airborne concentrations that approach or exceed 1 imits, removal should be done as soon as possible. If necessary for airborne concentration control, installation of ventilation systems in the cabinets should be evaluated.

\section{Decontamination}

No model was identified which could reasonably approximate airborne concentrations resulting from use of the decontamination station in room $2 \mathrm{~B}$. This activity should be monitored for lead and nitric acid initially, and then whenever decontamination methods change. Periodic monitoring requirements should be established based on the initial monitoring results.

\section{Solids Weighing}

Several solids are weighed in the 222-SA Standards Laboratory, genera11y in small amounts. This evaluation indicated that there is very little potential for elevated airborne chemical concentrations and no monitoring or other actions are recommended.

\section{Chemical Usage Outside of Hoods}

Few chemicals are used outside of a fume hood. To be conservative, for this evaluation it was assumed that any chemical in the inventory could be used outside of the hood. Based on frequency of use and physical properties of the chemicals, a list of 10 chemicals of concern was identified. Airborne concentrations were modeled with the scenario of an open beaker of the 
HNF-SD-SUP-LB-001, Rev. 0

chemical of concern evaporating for various time periods. Two ventilation scenarios were modeled: typical and worst case. The typical case modeling results were in close agreement with actual monitoring results and the typical case was generally used for summary information and making recommendations. Based on this evaluation, airborne limits could be exceeded within minutes with small liquid volumes for the following chemicals:

\section{Bromine}

Benzene

Hydrochloric Acid (> 30\%)

Ammonium Hydroxide $(>6 \mathrm{~m})$

Hydrofluoric Acid

According to facility personnel, these chemicals are only used inside of hoods. Any use outside of hoods should be strictly controlled and monitored unless dilutions are used. Dilutions of these chemicals should be further evaluated.

The airborne limits for epichlorohydrin and hydrogen peroxide could be exceeded with relatively small liquid volumes if the chemical was open outside of the hood for approximately 5 hours. The airborne limit for methylene chloride could be exceeded in approximately 4 hours but would require the evaporation of approximately 1 liter of liquid. These conditions are not likely unless an error is made. 
Limits probably would not be exceeded for the other chemicals used in the lab because they have high exposure limits or are not very volatile. Activities that force evaporation or particulates into the air should be further evaluated.

Although this analysis identified no other organic chemicals with potential exposures greater than limits, to demonstrate compliance monitoring should be performed annually if these chemicals are used outside of fume hoods. This is particularly true for methylene chloride in light of current regulatory efforts to reduce limits for this chemical.

To assist in this evaluation an airborne factor model was developed that accurately identified chemicals of concern. This airborne factor should be used to screen activities anticipated to be performed outside of hoods. This process could be incorporated in the Chemical Hygiene Plan. The recommended airborne factor screening level of 170 could be used to identify those chemicals that should be used inside of hoods or monitored. Volumes of chemicals required to exceed limits could also be incorporated.

Mercury Distillation

Airborne chemical concentrations from the mercury distillation, currently in room $4 \mathrm{~L}$, were not modelled because it is not in service. However, the inspection identified some areas of concern. There was no apparent ventilation system. No previous airborne mercury monitoring has been identified, and no surveys have been identified that clear the area of surface mercury. It is recommended that this unit not be operated until surface 
HNF-SD-SUP-LB-001, Rev. 0

monitoring is performed and engineering controls are implemented to ensure vapors are captured.

\section{Conclusion}

This evaluation indicates that airborne chemical concentrations in the 222-S Laboratory are low if current practices, including use of fume hoods, continue. However, airborne limits can easily be exceeded if certain chemicals of concern are used improperly. In some cases, additional monitoring is recommended because models do not adequately predict exposures. In other cases, monitoring is recommended to confirm low predicted concentrations. 


\section{TABLE OF CONTENTS}

ACRONYMS

1.0 INTRODUCTION ....................... 1 . . . . . .

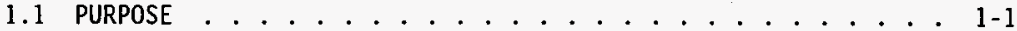

1.2 REPORT ORGANIZATION . . . . . . . . . . . . .

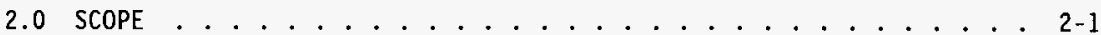

3.0 CHEMICAL HYGIENE PLAN ......................... 3-

3.1 CHEMICAL CATEGORIES ................. $3-1$

3.2 MONITORING REQUIREMENTS $\ldots \ldots \ldots . \ldots . \ldots . \ldots . \ldots$

4.0 FACILITY INFORMATION ................... 4-1

4.1 VENTILATION ..................... . . . . . . .

4.2 CHEMICAL STORAGE ...................... 4 . .

5.0 WORK PRACTICES . . . . . . . . . . . . 5-1

5.1 LABORATORY ROOM PRACTICES ............... 5- . . .

5.1 .1 Room 4L .................. 5-1

5.1 .2 Room $2 \mathrm{~B}$..................... 5-1

5.1 .3 Room 4P Organic Laboratory ............. 5-2

5.1.4 Room 4A Environmental Laboratory......... 5-2

5.1 .5 Room $1 \mathrm{~J}$ ICP RoOm . . . . . . . . . . . . 5-2

5.2222 -SA STANDARDS LABORATORY PRACTICES . . . . . . $5-2$

5.3 INSTA-GEL USAGE .................... $5-3$

5.4 CHEMICAL HYGIENE PLAN IMPLEMENTATION ......... 5-3

6.0 CHEMICAL INFORMATION ................... 6-1

6.1 FREQUENTLY ORDERED CHEMICALS . . . . . ...... 6- 6-1

6.2 HIGH POTENTIAL AIRBORNE CONCENTRATION CHEMICALS ..... 6-1

7.0 PREVIOUS AND CURRENT MONITORING EFFORTS ........... . . 7-1

8.0 ASSESSMENT MODELS . . . . . . . . . . . . . . 8-1

8.1 SCENARIOS ................. 8- . . . . .

8.2 STORAGE CABINET MODELS . . . . . . . . . . . . 8-1

8.2.1 Storage Cabinet Generation Mode1 . . . . . . . . 8-2

8.3 DECONTAMINATION MODEL . . . . . . . . . . 8-4

8.4222 -SA STANDARDS LABORATORY SOLIDS WEIGHING MODEL $\ldots . .8-4$

8.5 GENERAL CHEMICAL TRANSFER MODELS .......... $8-4$

8.5.1 Displacement Vapors Generation Rate . . . . . . 8-5

8.5.2 Displacement Vapors Dispersion .......... 8-6

8.5.3 Evaporation Generation Model . . . . . . . . 8-6

8.5.4 Evaporation Dispersion Mode1 . . . . . . . . . 8-7

9.0 AIRBORNE CHEMICAL CONCENTRATION ESTIMATES . . . . . . . . . . 9-1

9.1 STORAGE CABINET ESTIMATE . . . . . . . . . . . . 9-1

9.2 DECONTAMINATION ESTIMATES . . . . . . . . . . . . . 9-1

9.3 222-SA STANDARDS LABORATORY SOLIDS WEIGHING ESTIMATES . . . 9-2 
9.4 GENERAL CHEMICAL TRANSFER ESTIMATES . . . . . . . . . . 9-3

9.4.1 Chemicals Evaluated ............... 9-3

9.4.2 Displacement Vapors Airborne Concentration Estimates: 9-5

9.4.3 Evaporation Airborne Concentration Estimates .... 9-6

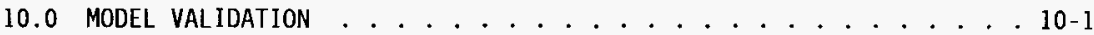

10.1 EXPOSURE MODEL VALIDATION ............. . . 10-1

10.2 SCREENING MODEL VALIDATION ............... . . . . . . .

11.0 AIRBORNE CHEMICAL MONITORING RECOMMENDED . . . . . . . . 11-1

11.1 ROOM 4L FLAMMABLE STORAGE CABINET . . . . . . . . . . . 11-1

11.2 ROOM 2B DECONTAMINATION STATION . . . . . . . . . . . 11-1

11.3 CHEMICAL USAGE OUTSIDE OF HOODS ............. . 11-1

11.4 MERCURY DISTILLATION ...................... . . . . . . . .

11.5 MAINTENANCE CHEMICALS . . . . . . . . . . . . . 11-2

12.0 MONITORING NOT RECOMMENDED . . . . . . . . . . . 12-1

12.1 SOLIDS MONITORING IN THE 222-SA STANDARDS LABORATORY .... 12-1

12.2 MOST CHEMICALS . . . . . . . . . . . . . 12-1

13.0 CONCLUSIONS AND OTHER RECOMMENDATIONS . . . . . . . . 13-1

13.1 PERFORM PERIODIC AND TASK SPECIFIC MONITORING . . . . . . . 13-1

13.2 EVALUATE HOOD USAGE . . . . . . . . . . . . 13-1

13.3 FURTHER EVALUATE AND MODIFY MERCURY DISTILLATION ..... 13-1

13.4 UTILIZE AIRBORNE SCREENING FACTOR AND VOLUME COMPARISON . . . 13-1

13.5 MONITOR STORAGE CABINETS AND EITHER REMOVE CHEMICALS OR

EVALUATE VENTING STORAGE CABINETS IF NEEDED ........ 13-1

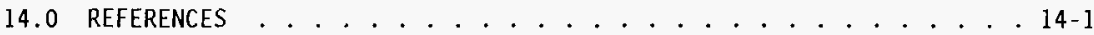

\section{APPENDIXES}

Appendix A Laboratory Chemical Inventory Information

Appendix B Storage Cabinet Model Information

Appendix C 222-SA Standards Laboratory Solids Weighing Model Information

Appendix D General Chemical Transfer Model Information

Appendix E Maximum Airborne Concentrations Under Typical Ventilation Conditions

Appendix F Average Airborne Concentrations Under Typical Ventilation

Conditions 


\section{LIST OF FIGURES}

Figure 9-1

Figure 9-2

Figure $9-3$

Figure 9-4

Figure 9-5

Table 6-1

Table 6-2

Table 7-1

Table 9-1

Table 9-2

Table 9-3

Table 9-4

Table 9-5

Table 9-6

Table 9-7

Table 9-8.

Table 10-1

Table 13-1
Airborne Concentration of Nitric Acid (57\%)

Based Upon Displacement . . . . . . . . . 9-6

Instantaneous Concentration of Methylene Chloride

in Room ................. 9-9

Maximum Concentration of Methylene Chloride in Room . . 9-10

Averaged Concentration of Methylene Chloride in Room . 9-11

Maximum Concentration of Hydrochloric Acid in Room at

Various Concentrations . . . . . . . . . 9-14

\section{LIST OF TABLES}

Most Frequently Ordered Chemicals at

222-S Laboratories ........... 6-2 Chemicals With Potential for Elevated Airborne

Concentrations ........... 6- 6-4

222-S Exposure Monitoring ....... 7-2

Storage Cabinet Airborne Chemical Concentration

Estimates . . . . . . . . . . 9-1

Evaluation of 222-SA Standards Laboratory Potential

Airborne Concentration ........... 9-3

Chemicals of Concern - Airborne Limits ...... 9-4

Maximum Airborne Concentrations Estimated from

Displacement ... . . . . . . . . 9-5

Chemicals of Concern Evaporation Rates ...... 9-8

Chemicals of Concern - Times to Reach Airborne Limits . 9-12

Chemicals of Concern - Equilibrium Concentrations.. 9-13

Chemicals of Concern - Volumes of Chemical Required . 9-15

Comparison of Screening Factors and Exposures.... . 10-2

Chemicals of Concern - Summary Information ..... 13-2 
HNF-SD-SUP-LB-001, Rev. 0

This page intentionally left blank. 


\section{ACRONYMS}

ACGIH

AIHA

ALARA

AMCA

CAS

CEIL

cfm

CFR

CSU

DOE

EPA

HEPA

IDLH

$1 \mathrm{fm}$

NFPA

OSHA

PEL

PNL

ppm

RWP

STEL

TLV

TWA

WSCF

WHC

American Conference of Governmental Industrial Hygienists

American Industrial Hygiene Association

as low as reasonably achievable

Air Movers Contract Association

Chemical Abstract Service

ceiling exposure

cubic feet per minute

Code of Federal Regulations

Chemical Storage Unit

U.S. Department of Energy

U.S. Environmental Protection Agency

high-efficiency particulate air

immediately dangerous to life or health

linear feet per minute

National Fire Protection Association

Occupational Safety and Health Administration

permissible exposure limit

Pacific Northwest National Laboratory

parts per million

radiation work permit

short-term exposure 7 imit

threshold limit value

time weighted average

Waste Sampling and Characterization Facility

Westinghouse Hanford Company. 
HNF-SD-SUP-LB-001, Rev. 0

This page intentionally left blank. 


\subsection{INTRODUCTION}

The 222-S Laboratory complex stores and uses over 400 chemicals. Many of these chemicals are used in laboratory analysis and some are used for maintenance activities. The majority of laboratory analysis chemicals are used only inside of fume hoods or glove boxes to control both chemical and radionuclide airborne concentrations.

This evaluation was designed to determine the potential for laboratory analys is chemicals at the 222-5 Laboratory complex to cause elevated airborne chemical concentrations during non-emergency conditions. Conditions and activities that should be subject to airborne chemical monitoring in accordance with the Westinghouse Hanford Company (WHC) Chemical Hygiene Plan were identified. To identify conditions associated with potential elevated concentrations, work areas were inspected, ventilation and storage conditions were reviewed, and past and current monitoring activities were reviewed. In addition, chemicals of concern were identified and models were developed to predict airborne concentrations.

\subsection{PURPOSE}

The purpose of this report was to document the evaluation of potential chemical airborne concentrations and controls at the 222-S Laboratory complex to determine the appropriate monitoring. This evaluation was performed to meet the monitoring criteria in Section 16 of the WHC Chemical Hygiene Plan (Sant 1995). The plan requires that potential employee exposures to hazardous chemicals be evaluated and that appropriate monitoring and/or sampling be conducted as required.

Chemical airborne concentrations at the 222-S Laboratory complex are aggressively controlled through the use of ventilation hoods, general ventilation, and work practices. As a result, chemical concentrations at these facilities are generally considered as low as reasonably achievable (ALARA).

\subsection{REPORT ORGANIZATION}

This report was designed to review several factors that affect potential elevated airborne chemical concentrations. The scope of this report is described in Section 2. Section 3 provides a general discussion of the Chemical Hygiene Plan. Section 4 describes the facility, including the ventilation and chemical storage systems. Work practices, which often have the largest influence on airborne concentrations, are reviewed in Section 5 . Frequently used chemicals are more likely to result in elevated airborne concentrations, and chemicals with high vapor pressures and molecular weights will typically result in greater airborne concentrations; these chemicals are discussed in Section 6 with additional information in Appendix A. Past monitoring history can also be an indicator of current exposures. Past and current monitoring efforts are described in Section 7 . Section 8 discusses the exposure assessment models used to estimate exposures and Section 9 presents the results of using these models. Appendixes B through F provide additional information on modeling results. Model validation is presented in 
HNF-SD-SUP-LB-001, Rev. 0

Section 10. Monitoring recommendations are included in Sections 11 and 12. Section 13 contains the general conclusions of this evaluation. 
HNF-SD-SUP-LB-001, Rev. 0

\subsection{SCOPE}

The scope of this report was limited to the 222-S Laboratory complex including the 222-SA Standards Laboratory and chemical storage unit (CSU). All 7 aboratory chemicals were identified and evaluated. Maintenance chemicals were not included because they are beyond the scope of the Chemical Hygiene Plan. Airborne chemical potentials were limited to normal activities.

Potential concentrations from spills, fires, or similar emergencies were not included. 
HNF-SD-SUP-LB-001, Rev. 0

This page intentionally left blank. 
HNF-SD-SUP-LB-001, Rev. 0

\subsection{CHEMICAL hYGIENE PLAN}

The 222-S Laboratory complex is operated in accordance with several sets of requirements including the Chemical Hygiene $\mathrm{Pl}$ an. This $\mathrm{plan}$ was written in accordance with the Occupational Safety and Health Administration (OSHA) requirements contained in Title 29 of the Code of Federal Regulations (CFR) Part 1910.1450, "Occupational Exposures to Hazardous Chemicals in Laboratories." The Chemical Hygiene Plan includes a general requirements section applicable to all laboratories under Fluor Daniel Hanford, Inc. control; information specific to each facility is included as an attachment to the plan. This plan is reviewed and updated annually.

The Chemical Hygiene Plan encompasses all phases of laboratory chemical usage including procurement, storage, protective apparel, handling precautions, monitoring, spills and emergency actions, and disposal. Most important to this evaluation were the handling precautions, which are based on chemical categories and monitoring requirements.

The chemical categories and associated handling requirements for chemicals in the 222-S Laboratory are discussed in Section 3.1. Monitoring requirements are discussed in Section 3.2. The information in Section 3.1 and 3.2 is from the Chemical Hygiene Plan. Implementation of this plan is discussed in Section 5.4.

\subsection{CHEMICAL CATEgORIES}

Three general chemical categories (A, B, and C) are used in the Chemical Hygiene Plan. Category $C$ chemicals are considered the least hazardous category of materials to work with and include some irritants and corrosives. Category $B$ chemicals are substances of moderate chronic toxicity or high acute toxicity and include sensitizers and reproductive toxins. Category $A$ chemicals include substances of known high chronic toxicity, materials regulated by OSHA, and materials regulated by the U.S. Department of Energy (DOE). Administrative controls that must be implemented for each chemical category to ensure health hazard control are described in the following text.

Laboratory personnel are required to perform all activities involving hazardous chemicals (Category $A, B$, and $C$ ) by following approved procedures or work plans. New laboratory operations not covered by approved procedures or work plans require prejob planning and use of the Job Safety Analys is program, as required by WHC-CM-4-3, Industrial Safety Manual, Standard A-3, "Prejob Planning", and the new WHC-CM-4-10 or the equivalent (WHC-CM-6-1, Standard Engineering Practices, EP-4.2, "Testing Practices").

Additional precautions for Category B chemicals include containment devices, personal protective equipment, proper storage, and waste handling procedures. In general, radiation work permit (RWP) precautions, where applicable, satisfy the chemical hygiene requirements for this class of chemicals. Category B chemicals are handled only by trained, designated, and approved personnel following approved procedures. Materials that cannot become airborne (i.e., are not fine powders, are not volatile, or are present at less than $1 \%$ in solution) may be worked with outside of a hood. 
HNF-SD-SUP-LB-001, Rev. 0

Substances of known high chronic toxicity are handled only by trained, designated, and approved personnel who are following procedures for handling Category A materials. These chemicals and materials are shown on the facility specific Chemical Hygiene Lists as Category A hazardous chemicals, and include: (1) substances of known high chronic toxicity, (2) OSHA-regulated materials, and (3) DOE-regulated materials (e.g., beryllium compounds).

Each facility has designated a controlled area or areas for work involving Category A materials. Only trained, approved personnel, with current training records, handle these materials. Personnel must work with these chemicals in a physical containment device. Managers and supervisors must be notified of each use and are required to record the following for Category A materials: (1) amounts stored, (2) amounts used, (3) dates of use, and (4) the names of employees using these materials.

Facility specific procedures vary for the handling of Category $A$ and Category $B$ materials. The 222-S Laboratory complex requires locked doors with limited key distribution for Category $B$ and requires that only small quantities of Category $A$ materials be stored in room $4 \mathrm{~L}$ and room $1 \mathrm{G}-\mathrm{C}$ for use as standards and reference materials. Hood 1 and the hood in room $1 G-C$ are the designated Category A hoods. Special clothing, including two pairs of gloves and Tyvek (Tyvek is a trademark of E.I. du Pont de Nemours and Company) 1 ab coats are required for Category A work. "Cancer hazard" postings are also required.

The 222-SA Standards Laboratory has identified Hoods 1, 2, 3, and 4 for Category B chemicals and Hood 1 for Category A chemicals. Protective clothing and other controls are similar to those used in the 222-S Laboratory complex.

The Chemistry Statistics Laboratory requirements are the most restrictive and require (1) a test plan, (2) consultation with the Chemical Hygiene Officer, and (3) posting of the area for both Category $A$ and $B$ chemicals prior to working with any chemical.

\subsection{MONITORING REQUIREMENTS}

This evaluation is designed to identify the monitoring requirements in accordance with the Chemical Hygiene Plan. The monitoring requirements for the 222-S Laboratory are described in the Chemical Hygiene Plan as follows:

An employee's exposure to any hazardous chemical regulated by an OSHA standard shall be evaluated. The following procedures must be implemented by line management.

1. Identify the monitoring that must be conducted.

a. Survey the raw materials and determine whether potentially harmful materials are being used.

b. Identify the conditions under which these materials are being used and the processes that generate physical hazards. 
HNF-SD-SUP-LB-001, Rev. 0

c. Determine whether the materials or processes may present a potentially harmful exposure to employees.

2. Contact Industrial Hygiene Representative for determination of whether area monitoring or personnel sampling are required. 
HNF-SD-SUP-LB-001, Rev. 0

This page intentionally left blank. 


\subsection{FACILITY INFORMATION}

An actively maintained and monitored ventilation hood configuration is the foundation of the 222-S Laboratory complex airborne contaminant control system. Although radiological controls are the principal driver for hood requirements, the same controls are equally effective for controlling chemical concentrations. Nearly a 11 work is performed either in hoods or in totally contained hot cells. This section describes the engineering aspects of the ventilation system. Also included is a brief description of the chemical storage system.

\subsection{VENTILATION}

The ventilation hoods in the $222-5$ Laboratory complex are designed to meet the criteria from the DOE General Design Criteria, DOE Order 6430.1A (DOE 1989), the Radiological Design Guide (Evans 1994), and the 222-S Laboratory Interim Safety Basis (Weaver 1996). The minimum flow rate in each hood is 125 linear feet per minute $(1 \mathrm{fm})$. This corresponds to a minimum flow of 195 or 725 cubic feet per minute $(\mathrm{cfm})$, depending upon the hood style (Drawing H-299485). All hoods are verified monthly in accordance with procedure 3-PL-016. All hoods are fed into a common header which is exhausted through high-efficiency particulate air (HEPA) filters above building level to properly disperse nonradiological components.

There are a minimum of five air changes per hour in each room in the 222-S Laboratory complex and an average of approximately seven air changes per hour for the entire complex. Because of differences in the number and type of hoods in each room, there can be significantly greater air changes on a per room basis. The monthly measured air flow rates for each hood in the room combined with the measurements of exhaust air are used to determine the air change rate for each room.

Ventilation studies were performed to confirm air flow patterns and removal capabilities (Stoetzel and Hickey 1990; Stoetzel and Cicotte 1992). Smoke tubes, smoke bombs, and anemometers were used in these studies. In most laboratory rooms, the air flow was generally 10 to $301 \mathrm{fm}$ with 1 ocalized higher flow areas, particularly at the hood openings. Air clearances were generally measured as "less than 15 minutes."

The high air exchange rate is effective at controlling the potential exposure from the few operations performed outside of hoods or other controlled areas (Section 5).

The 222-S Laboratory complex is in the process of upgrading several of the laboratory rooms. Continued future use of the hoods is a requirement of these upgrades.

\subsection{CHEMICAL STORAGE}

Bulk chemicals are primarily stored in separate specially designed buildings with individual ventilation systems. Smaller chemical quantities are stored in laboratory cabinets within the 222-S Laboratory complex. Some flammables are also stored inside in flammable cabinets. One item noted was 
that no storage cabinets appeared to be vented. Prudent Practices for Handling Hazardous Chemicals in Laboratories (National Research Council 1981), cited in OSHA laboratory standard 29 CFR 1910.1452, recommends that toxic substances be stored in cabinets fitted with auxiliary ventilation systems. Venting of flammable storage cabinets must be done in accordance with National Fire Protection Association (NFPA) 30, Flammable and Combustible Liquids Code, (NFPA 1991) and approval of the local fire protection representative. 


\subsection{WORK PRACTICES}

Work practices in the 222-S Laboratory complex were evaluated to determine places and activities that may result in increased chemical airborne concentrations. These work practices were identified during a tour on July 24, 1996, previous experience with this facility, and worker discussions. observations in each laboratory room where exposures could occur are summarized in Section 5.1, 222-SA Standards Laboratory practices are described in Section 5.2, Insta-Gel (Insta-Gel is a trademark of Packard Instruments) usage is discussed in Section 5.3, and implementation of the Chemical Hygiene Plan is described in Section 5.4.

\subsection{LABORATORY ROOM PRACTICES}

This section identifies each room at the 222-S Laboratory and describes the practices performed in the room. The practices described are general work practices and are not inclusive of all laboratory activities.

\subsubsection{Room 4L}

Room $4 \mathrm{~L}$ is primarily used to store and package materials for disposal. In addition to fume hoods, this room contains four flammable materials cabinets and a mercury distillation unit. These units were previously stored in Room 4E. Workers report that there is an organic smell when some of the cabinets are opened. These cabinets contain several organic materials that have been stored for an extended period of time awaiting disposal. When in Room $4 \mathrm{E}$, cabinet 2 was equipped with charcoal adsorption canisters that were likely installed to adsorb organic vapors. These canisters are effective only if they are changed frequently.

The 222-S Laboratory complex personnel were provided with a Tedlar (Tedlar is a trademark of E.I. du Pont de Nemours and Company) bag sampling kit to retrieve a gas sample from Cabinet 2 . The laboratory used infrared fourier transformer based analytical equipment to attempt to identify the organics present. This monitoring was not successful. Additional screening is underway. Because monitoring the airborne concentrations from Cabinet 2 was unsuccessfu1, a conservative model was used to estimate the potential chemical airborne concentrations. The model used is described in Section 8.2 and the concentrations estimates resulting from the model are presented in Section 9.1 .

The mercury distillation unit, that was previously in room $4 \mathrm{E}$, is not currently in operation. It is unknown if there have been any spills from the mercury distillation unit.

\subsubsection{Room 2B}

Room 2B contains the decontamination station. Most decontamination is performed inside of hoods. Items decontaminated include laboratory glassware and lead shielding. The chemical used most often for decontamination is concentrated nitric acid. Ethyl alcohol was also present in the room, outside of the hood, in a small squirt bottle. 
HNF-SD-SUP-LB-001, Rev. 0

In addition, this room receives decontamination waste from the Waste Sampling and Characterization Facility (WSCF). During the tour there was a 55-gal drum from WSCF in room 2B. Understandably, this drum cannot be opened inside of a hood. However, according to personnel at the 222-S Laboratory, this waste must have less than $2 \%$ organic content to be put into the 222-S Laboratory complex system. Because of this restriction, the potential airborne chemical concentrations are considered very low.

The greatest potential for airborne chemical concentrations in this room is likely from acid splashing in the hoods during the decontamination of lead. This exposure was evaluated based on the Industrial Hygiene Ventilation Manual (ACGIH 1988) (see Sections 8.3 and 9.2).

\subsubsection{Room 4P Organic Laboratory}

Several organic materials, including methylene chloride, are used in the room 4P organic laboratory. Use of this room has decreased with the opening of WSCF; however, airborne chemical concentrations are still possible. Previous monitoring in this room indicated that chemical airborne concentration levels are generally low (Section 7). Modeling has also been performed to determine the potential chemical airborne concentrations that could result if normal laboratory practices and procedures are not followed (see Sections 8.5 and 9.4 ).

\subsubsection{Room 4A Environmental Laboratory}

In this room there are several large (approximately 5-gal) bottles containing various acids outside of hoods. Liquids are poured, through a spigot, to beakers. These beakers are transferred to hoods for chemical evaluations. The highest concentration liquid is 9 molar nitric acid. There are plans to remove these acid bottles. Modeling has been performed to determine the potential airborne concentrations that could result from general chemical transfers, including activities performed in room $4 \mathrm{~A}$ (see Sections 8.5 and 9.4 ).

\subsubsection{Room 1J ICP Room}

Five percent nitric acid is used in this room outside of hoods. This acid is pipetted in small quantities as an analysis step. Because of the small volumes and low vapor pressure of this concentration of nitric acid, airborne chemical concentrations exceeding applicable limits is not considered an issue. In addition, the modeling performed in Sections 8 and 9 includes this activity.

\subsection{2-SA STANDARDS LABORATORY PRACTICES}

Most analysis chemicals are mixed in the 222-SA Standards Laboratory. As a result, this $1 \mathrm{ab}$ contains the most solids (for weighing) and has the most operations performed outside of hoods. The solids used are nonradioactive and typically weighed in quantities of $10 \mathrm{~g}$ or less. Up to approximately $1 \mathrm{~kg}$ of solid is weighed approximately one to two times each year. 
Solids generation is not nearly as great a concern as vapor generation. Unless the particle size is extremely small and there is some agitation mechanism, the generation rates for solids are much smaller than generation rates for volatile organic liquids. This is particularly true for the activities performed in the 222-SA Standards Laboratory. This position is supported by references, which provide 1 ittle discussion of capturing dust unless there is some active mechanism to generate the dust (National Research Council 1981, ACGIH 1988). However, the potential for increased airborne concentrations has been raised and was evaluated as part of this study (Sections 8.4 and 9.3 ).

\subsection{INSTA-GEL USAGE}

Insta-Gel is one of the most frequentiy procured chemicals. This chemical is used as a scintillation cocktail for radiochemical evaluations. The primary component in Insta-Gel is 1,2,4-trimethyl benzene. Each usage of Insta-Gel is approximately $20 \mathrm{~mL}$. Airborne levels, based upon previous monitoring, are low (Section 6). Insta-Gel is included in the airborne chemical evaluation (Sections 8.5 and 9.4).

\subsection{CHEMICAL HYGIENE PLAN IMPLEMENTATION}

The Chemical Hygiene Plan is relatively new and is still in the process of being implemented. Categorization of all chemicals was just recently completed. Initial efforts to implement the categorization system into procedures revealed significant limitations with the approach as written. Efforts are ongoing to modify the Chemical Hygiene Plan to be consistent with newer laboratory guidance documents. Consequently, there was little evidence of work practices involving the categorization system. However, carcinogens, which make up the bulk of the most restricted chemicals, are controlled. 
HNF-SD-SUP-LB-001, Rev. 0

This page intentionally left blank. 


\subsection{CHEMICAL INFORMATION}

The 222-S Laboratory complex currently maintains an inventory of over 400 chemicals. Most of these chemicals are used in relatively small quantities. Other chemicals are used for maintenance activities (e.g., paints). Additional information on the laboratory chemicals, not including maintenance chemicals, is provided in Appendix $A$ and includes the chemical name, Chemical Abstract Service (CAS) number, and quantity present as of July 15, 1996. Also included in Appendix A are information on vapor pressure, molecular weight, and applicable airborne concentration limits. This latter information was used for modeling in Sections 8 and 9.

This section identifies those chemicals most frequently ordered and those that have the greatest potential to exceed airborne limits based on physical properties. These chemicals form the list that is modeled in Sections 8.5 and 9.4 .

\subsection{FREQUENTLY ORDERED CHEMICALS}

The total quantity of chemicals ordered each year is important as an indicator of potential elevated airborne concentrations. The 10 chemicals most frequently ordered between January 1994 and June 1996, according to ordering records, are provided in Table 6-1. All of the chemicals on Table 6-1, with the exception of standards and isotopes, were evaluated for potential airborne chemical concentrations. Standards and isotopes are usually used only in small quantities and are often in solutions of methylene chloride or nitric acid, both of which are evaluated for potential airborne concentrations.

\subsection{HIGH POTENTIAL AIRBORNE CONCENTRATION CHEMICALS}

Airborne chemical concentrations are often related to the physical properties of the chemicals. The two primary physical properties affecting airborne concentrations are molecular weight and vapor pressure. These two physical properties, along with airborne limits, can be used to derive an airborne factor to screen chemicals for additional evaluation. The airborne factor is based on Equation 6-1.

\section{Equation 6-1:}

$$
\text { Airborne Factor }=\frac{(V P)(M W)}{A L}
$$

Where:

$$
\begin{aligned}
V P & =\text { Vapor pressure }(\mathrm{mmHg}) \\
M W & =\text { Molecular weight } \\
A L & =\text { Airborne limit }\left(\mathrm{mg} / \mathrm{m}^{3}\right)
\end{aligned}
$$


Table 6-1. Most Frequently Ordered Chemicals at 222-s Laboratories.

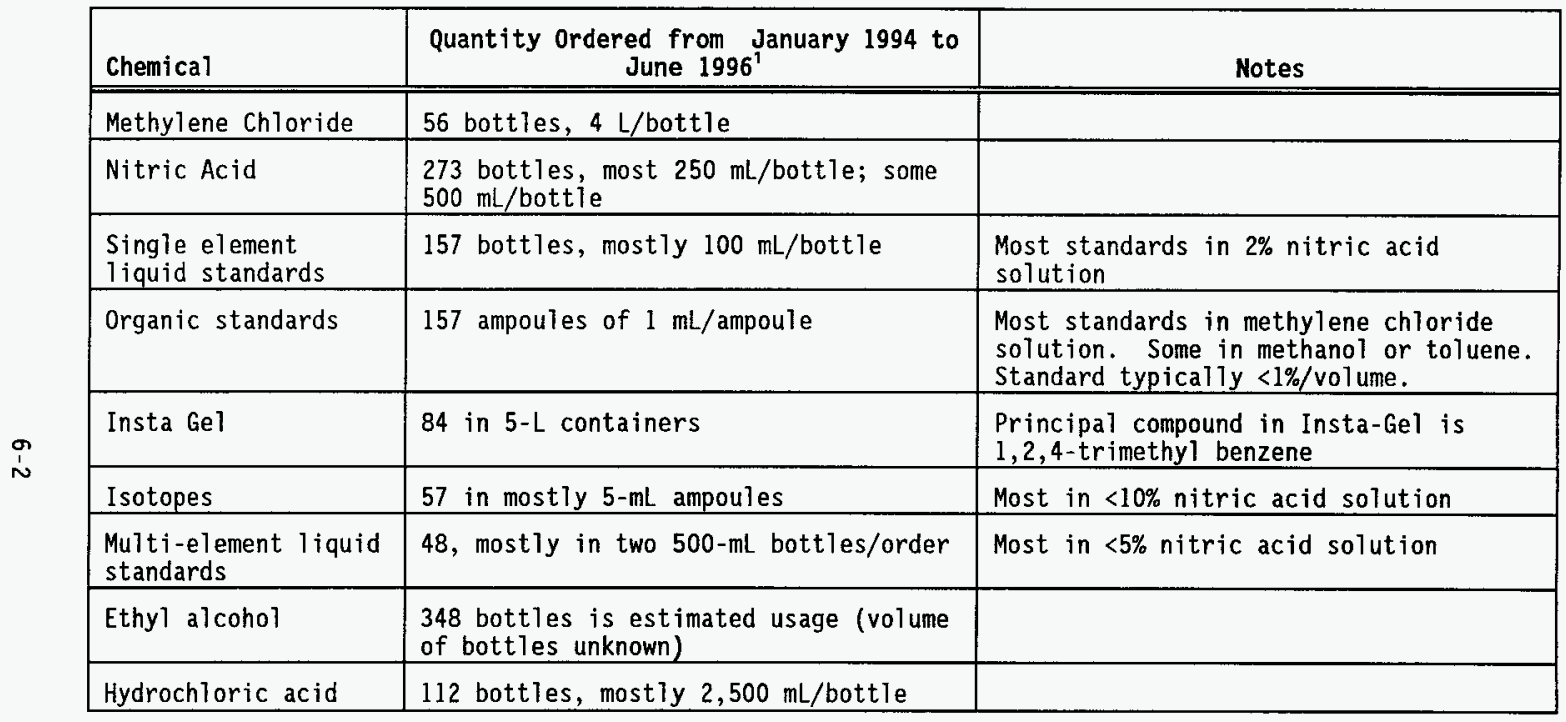

1 Based on information provided by 222-s Laboratory chemical ordering personnel. 
Based on this airborne factor concept, the chemicals at the 222-S Laboratory complex with the highest potential for airborne concentrations greater than the limits are provided in Table 6-2. The airborne limits used on the Hanford Site are the most restrictive of either the OSHA Permissible Exposure Limits (PELs) from 29 CFR 1910 Subpart $Z$ or the American Conference of Governmental Industrial Hygienists (ACGIH) Threshold Limit Values (TLVs). Gases are omitted from this list because high concentrations are assumed if gas is released. Potential concentrations from these chemicals are evaluated in Section 9.4. Validation of this method is provided in Section 10.1.

of the 10 high airborne potential chemicals identified, only two are known to be used outside of hoods: $n$-hexane and methylene chloride. N-hexane use outside of hoods is frequently performed during organic analysis for dilution of standards and sample extracs using 1 to $10 \mathrm{~mL} n$-hexane volumes.

Methylene chloride is used as follows:

- A 1-L aqueous sample is transferred to a continuous liquid-liquid extractor. Approximately $300 \mathrm{~mL}$ of methylene chloride is added and contained within the extractor. After the extraction is completed ( 18 to 24 hours), the boiling flask containing the methylene chloride is removed and transferred to a fume hood for continuing work.

- A 1-L aqueous sample is transferred to a separatory funnel. After a $\mathrm{pH}$ adjustment, $60 \mathrm{~mL}$ of methylene chloride is added to the separatory funnel. The separatory funnel is sealed and vigorously shaken for 1 to 2 minutes with periodic venting to release excess pressure. This venting is performed in a fume hood to avoid exposure of the analyst to solvent vapors. The organic layer is allowed to separate from the water phase for a minimum of 10 minutes. The solvent extract is then collected in a KudernaDanish concentrator.

The extraction process is then repeated two more times using fresh portions of methylene chloride. The Kuderna-Danish concentrator, containing the combined extracts, is transferred to a fume hood for continuing work.

Each methylene chloride procedure was performed approximately 16 to 20 times in the last 12 months. 
Table 6-2. Chemicals with Potential for Elevated Airborne Concentrations.

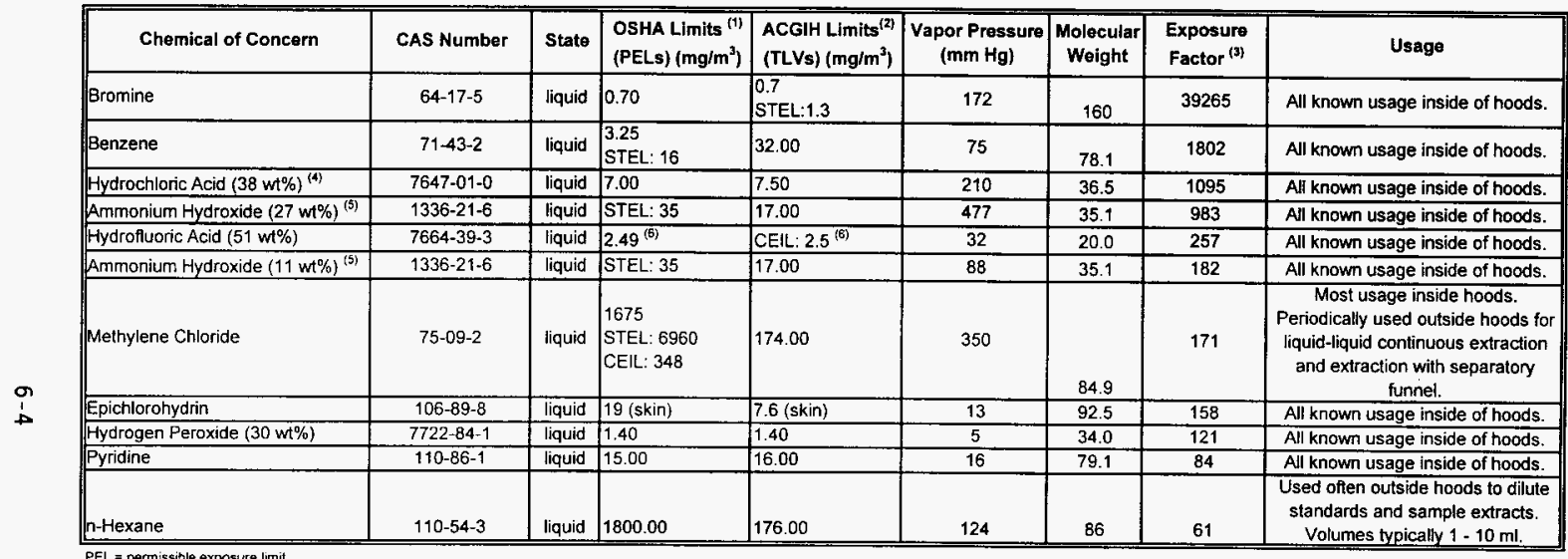

EL = permissible exposure limi

TLV = threshold limit vaiue

(1) From 1996 MSA Response Respirator Selector, and OSHA 29CFR1910, Subpar Z

(2) From 1996 MSA Response Respirator Selector, and ACGIH "TLV for Chemical Substances and Physical Agents", 1994 - 1995

(3) (VP)(MWM/(Exp. Leveii). Exposure level used is most restrictive of OSHA or ACGIH

(4) Hydrochloric acid results highly dependent on concentration. See Section 9.4.3.1

(5) Ammorium Hydroxide as ammonia

(6) PEL and TLV for HF as F 


\subsection{PREVIOUS AND CURRENT MONITORING EFFORTS}

In recent years, most industrial hygiene monitoring has been for asbestos, accounting for over $90 \%$ of the monitoring since 1989 . As a result, the asbestos work at the 222-S Laboratory complex can be considered we 11 characterized. Lead has also received additional attention and lead concentrations are part of an ongoing review. Because these materials are fairly well characterized and asbestos work is not a laboratory function, this section will focus on chemicals other than asbestos and lead. However, lead concentrations are still an area of potential concern (Section 9.2). The source of information for this review is the Hanford Industrial Hygiene Exposure Database, accessed July 9, 1996.

Since 1989, monitoring has been performed for 57 chemicals during 17 sampling events. In all of this monitoring, 27 chemicals were indicated at less than detectable concentrations and none were greater than permissible airborne concentration limits. The rooms and activities most frequently monitored were rooms $4 \mathrm{E}$ and $4 \mathrm{P}$. The highest concentration indicated was 60 parts per million $(\mathrm{ppm})\left(208.8 \mathrm{mg} / \mathrm{m}^{3}\right)$ methylene chloride in room 4P. This was a short-term exposure that resulted in an 8 -hour time weighted average (TWA) of $6.5 \mathrm{ppm}\left(22.6 \mathrm{mg} / \mathrm{m}^{3}\right)$. This monitoring event was used to validate the exposure models described in Section 8 (see also Section 10.1). Of all the chemicals monitored, methylene chloride concentrations in room 4P were generally the highest. A summary of the chemical monitoring performed in the 222-S Laboratory complex since 1989 is provided in Table 7-1. 
Table 7-1. 222-S Exposure Monitoring.

Sheet 1 of 2

\begin{tabular}{|c|c|c|c|c|c|c|c|}
\hline REC & Chearical & Date & $\begin{array}{c}\text { Roon } \\
\text { Monitored }\end{array}$ & $\begin{array}{c}\text { Result } \\
\text { (ppm) }\end{array}$ & $\begin{array}{c}8 \text { hr } \mathrm{Tu} \\
\text { (ppas) }\end{array}$ & $\begin{array}{c}\text { PEL } \\
\text { (pPI) }\end{array}$ & Metivity \\
\hline 5976 & Total Hydrocarbons & $7 / 1 / 91$ & $1 F$ & 2 & 2 & $\mathrm{NA}$ & FID Measurenent \\
\hline 5976 & Total Hydrocarbons & $7 / 1 / 91$ & $1 F$ & 5 & 5 & NA & PID Measurement \\
\hline 16344 & 1 Butanol & $2 / 2 / 9$ & $1 \mathrm{t}$ & 0.0165 & 0.0165 & & Chemicel hand I ing \\
\hline 16345 & 1-Butanol & $2 / 2 / 95$ & 11 & 0.114 & 0.114 & & chen ical hand $\mathrm{Ing}$ \\
\hline 16344 & 2-Butoxy Ethanol & $2 / 2 / 95$ & $1 \mathrm{~L}$ & 0.0309 & 0.0309 & 25 & Chemical handls ing \\
\hline 16345 & 2-Butoxy Ethonol & $2 / 2 / 95$ & 11 & 0.249 & 0.249 & 25 & Chentcal handling \\
\hline 16344 & 2olethyl hexane & $2 / 2 / 25$ & 11 & 0.0177 & 0.0177 & & chentical handl ing \\
\hline 16344 & Acetone & $2 / 2 / 95$ & 11 & 0.0215 & 0.0215 & 750 & Chenical hand Ing \\
\hline 16345 & Acetone: & 212195 & 11 & 0.0466 & 0.0466 & ro & chemical hand ing \\
\hline 16345 & Buty L Al dehyde & $2 / 2 / 95$ & 16 & 0.25 & 0.25 & & Clienical fiandiling \\
\hline 16346 & Ethryl Alcohol & $212 / 95$ & 11 & $\mathbf{0 , 1}$ & $\times 0.1$ & 1000 & Chemical handling \\
\hline 16345 & Ethyl Alcohol & $2 / 2 / 95$ & $1 \mathrm{t}$ & 0.25 & 0.25 & 1000 & chemlcal handling \\
\hline 16344 & Ethyl Alcohol & $2 / 2 / 95$ & $1 \mathrm{t}$ & 1, & 10 & 1000 & Chemical hand ing \\
\hline 16345 & Isopropyl Alcohol & $2 / 2 / 95$ & 14 & 0.25 & 0.25 & 400 & Chemilos loandly ing \\
\hline 16345 & Methyl Ether & $2 / 2 / 95$ & 14 & $\$ 0.250$ & 30.25 & & chenlcal haindling o present ot hilghest concentration in semple \\
\hline 16365 & Hethyl Ethyl Ketone & $2 / 2 / 95$ & 11 & 0.0266 & 0.0246 & 200 & Chenical hand long \\
\hline 16345 & sec-Butyl al coliol & $2 / 2 / 95$ & 14 & 0.25 & 0.25 & 100 & chemical handling \\
\hline 16364 & Toluene & $2 / 2 / 95$ & 11 & 0.0259 & 0.0259 & 50 & chenical handl he \\
\hline 5341 & Hydrogen chloride & $2 / 6 / 91$ & 48 & $<0.061$ & $<0.026$ & 5 & Performing Versapor Filter Dissolution \\
\hline 5341 & Hydrogen Fluoride & $2 / 6 / 91$ & 48 & $<0.067$ & $<0.028$ & 3 & Performing Versapor Filter Dissolution \\
\hline 5341 & Nitric Acid & $2 / 6 / 91$ & $4 B$ & $<0.28$ & $<0.12$ & 2 & Performing versapor filter Dissolution \\
\hline 5347 & Nitrogen Dioxide & $2 / 6 / 91$ & 48 & $<0.053$ & $<0.011$ & 1 & Performing Versapor Filter Dissotution \\
\hline 5341 & Nitrogen Dioxide & $2 / 6 / 91$ & $4 B$ & $<0.206$ & $<0.045$ & 1 & Performing Versapor Filter Dissolution \\
\hline 5341 & Nitrogen Dioxide & $2 / 6 / 91$ & $4 B$ & 75 & 75 & 1 & Performing Versapor filter Dissolution - Sample Inside Hood 2 \\
\hline 6158 & Acetonitrite & $6 / 28 / 91$ & $4 \mathrm{E}$ & $<0,2$ & \$0.2. & 6. & Unknoun Hazardous Hater ials stored in Hood - Sample Iaken in Hood \\
\hline 6158 & Carbon Tetrachloride & $6728 / 91$ & 4E: & $<0,05$ & 50.05 & 2 & Unknoun Hiazar dous Mater ials stored in Hood o semple Jaken hn Hood \\
\hline 6158 & Hydrogen chloride & $6 / 28 / 91$ & $4 \mathrm{E}$ & 0.06 & 0.06 & 5 & Unknoum Hazardous Materlats stored In flood - sample token in hood \\
\hline 6158 & bydrogen f Luoride & $6 / 28 / 91$ & 媞: & $<0.05$ & so.05 & 3. & Unknown Gazardous Mater lals stored In flood S Sample taken in hood \\
\hline 8256 & Methylene chloride & $11 / 1491$ & $6 \mathrm{E}$ & 0.3 & 0.03 & 50 & Transferring uaste solvent from $4 \mathrm{P}$ so $4 \mathrm{E}$ V \\
\hline
\end{tabular}


Table 7-1. 222-S Exposure Monitoring.

\begin{tabular}{|c|c|c|c|c|c|c|c|}
\hline REC: & Cheaical & Date & $\begin{array}{c}\text { Room } \\
\text { Monitored }\end{array}$ & $\begin{array}{c}\text { Result } \\
\text { (ppq⿴囗) }\end{array}$ & $\begin{array}{c}\text { 8-hr Tu' } \\
\text { (ppan) }\end{array}$ & $\begin{array}{c}\text { PEL } \\
\text { (PPM) }\end{array}$ & Activity \\
\hline 6158 & Hotric Acid & $0 / 28 / 91$ & $4 E$ & 0.02 & $\times 0.02$ & 2 & Unknown Hazardous Mater lats stored in tood - Sample Taken in Hood \\
\hline 6158 & sulturic Acid & $6 / 28 / 91$ & 6E & <0.07 & 60.07 & 0.25 & 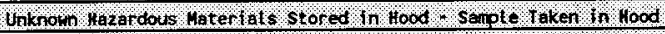 \\
\hline 6758 & toluene & $3 / 28 / 91$ & 4 . & $<0,02$ & 60.02 & 100 & Unknown Hazardous Materiats stored in hood S sample Taker in hood \\
\hline 6158 & Trinethyl Benzene & $6 / 28 / 91$ & $4 \mathrm{E}$ & $\times 0.04$ & 50.04 & 25 & Uaknown Hazardous Mater lats stored in Hood, sanple Taken in hood \\
\hline 6158 & xylene 0.0 & $6 / 28 / 91$ & 4E & $<0.02$ & $<0.02$ & 100 & Unknown fifazardous Mater lats stored in Hood Sample Taken in Hood \\
\hline 13211 & xylene & $10 / 26 / 93$ & 4E & 0.10 & 0.1 & & Sorting/disposing liquid scint viats, organic cabinet open. \\
\hline 6868 & Irimethyl Benzene & $8 / 7 / 91$ & $4 \mathrm{~N}$ & $<0.02$ & $<0.003$ & 25 & Repackaging Insta-Gel viles \\
\hline 6869 & Trimethyl Benzene & $8 / 7 / 91$ & $4 \mathrm{~N}$ & 0.28 & 0.28 & 25 & Repackaging Insta-Gel viles \\
\hline 8257 & Acetone 10 & $11 / 20 / 91$ & 4P & $<0.08$ & 80.03 & 750 & Rinsing olassware, filter ing \& Evap, saiples \\
\hline 8258 & Acetone & $2 / 4,92$ & 19 & $<0,14$ & 60.03 & 350 & setrling op extraction in hood \\
\hline 8237 & Asetone & $2 / 4 / 92$ & $4 \mathrm{P}$ & $<0.14$ & 60,14 & T5o & Setting up extraction in hood 8 , \\
\hline 8276 & Acettone & $2 / 4 / 92$ & $4 \mathrm{P}$ & $<0.28$ & $<0.03$ & so & 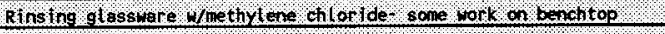 \\
\hline 8251 & Acetone & 11114191 & 4P. & 1.4 & 0,52 & 750 & Solvent extract ions in hood and on benathtop, \\
\hline 8259 & Acetone & $2,5 / 92$ & 48 & 3.1 & 1.57 & 750 & Taking down extract lontevapor at fon equiponent \\
\hline 8258 & Hexane & $2 / 4 / 92$ & 4P. & 0.05 & $<0.01$ & 50 & setiting co extractron in hood \\
\hline 8237 & Hexane & $2 / 4 / 92$ & $4 \mathrm{P}$ & $<0.05$ & 0.05 & 50 & Setuing op extraction in hood $8,1,1 \%$ \\
\hline 82.5 & Hexane & $2,4,92$ & 40 & $<0.09$ & 60.01 & 50. & 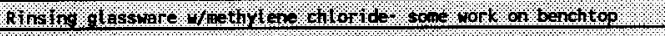 \\
\hline B256. & Methylene chloride & $11 / 14 / 91$ & 49 & 0.3 & 0.03 & 50 & 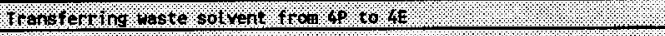 \\
\hline 8259 & Methylene Chlor loe & $2,5 / 92$ & 49 & 4.1 & 2.1 & 50 & Toking doun extracti ony evaporation equfpenent \\
\hline 8258 & Nethylene chloride & $2 / 14 / 92$ & 6P & 9 & 2.11 & 50 & Setring up extrect ton in hood \\
\hline 8257 & Methylene chlor lde & $11 / 20 / 21$ & 4p & 22 & 3. & 50 & 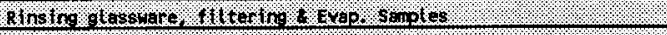 \\
\hline 8237 & Wethylene chloride & $2 / 4,92$ & $8 \mathrm{P}$ & 14 & 14: & 50 & 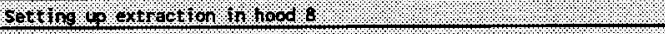 \\
\hline 8251 & Hethylene chlor lde & $11 / 14 / 91$ & 4P. & 27 & 10 & 50 & solvent extractions in hood and on bencheop \\
\hline 8275 & Hethylene chlor ide & $2 / 4 / 92$ & $4 \mathrm{P}$ & 60 : & 6.5 & 50 & 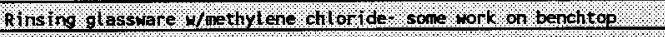 \\
\hline 8259 & Ooluene & $2,5 \% 92$ & 49 & 0.04 & \%0.02 & 100 & 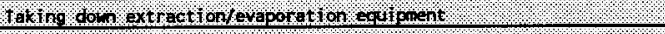 \\
\hline 8258 & Toluene & $2 / 14 / 92$ & 49 & \$0.086 & 0.02 & 100 & Stetting up extraction in irood \\
\hline 8237 & Woluene & $2 / 4 / 92$ & 4p & $\$ 0.086$ & $\times 0.006$ & 100 & Serting op oxtroct ton in hood 8 . \\
\hline 825 & Tolvene & $274 \% 2$ & 4 & 60.18 & 60.02 & 800 & 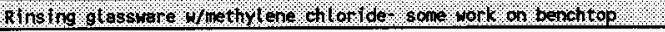 \\
\hline
\end{tabular}

From Hanford Industrial Exposure Database, accessed July 9, 1996

1 values in italics are estimated. In all cases, estimated 8-hr TWA values equaled measured results because there was insufficient information ayailable to establish actual length of activity. 
HNF-SD-SUP-LB-001, Rev . 0

This page intentionally left blank. 
HNF-SD-SUP-LB-001, Rev. 0

\subsection{ASSESSMENT MODELS}

The models chosen for this evaluation were designed to predict airborne chemical concentrations and were based on U.S. Environmental Protection Agency (EPA), ACGIH, and American Industrial Hygiene Association (AIHA) Guidelines (EPA 1991; ACGIH 1988; AIHA and ACGIH 1996). Different models are used but all are based on a two-stage approach: (1) predict the generation rate of the component and (2) predict the dispersion. The models used and justification for each are provided in this section.

Additional modeling information is provided in Appendixes B through $F$. The information in these appendixes is generally presented as problem statements with subsequent assumptions, calculation data, and results.

\subsection{SCENARIOS}

As a result of site tours and personnel interviews, four scenarios were identified that could result in elevated airborne chemical concentrations. These scenarios are as follows:

- Room 4L Storage Cabinet Work. In Room 4L there are four flammable material storage cabinets. An organic odor is detected when at least one of these cabinets is opened. Modeling of the distribution of chemicals from this cabinet would help determine potential airborne concentrations and recommended actions.

- Room 2B Decontamination Station Work. Decontamination of glass and lead could result in elevated airborne levels. Levels greater than permissible limits are considered highly unlikely due to the chemicals used and the use of hoods. Modeling of decontamination is difficult because solids, liquids, and vapors are involved. However, available data could indicate the potential for elevated levels of chemical airborne concentrations.

- Standard Lab Solids Weighing. Most solids in the 222-S Laboratory complex are used in the 222-SA Standards Laboratory. The weighing of these solids outside of a hood may result in increased airborne levels. Modeling of the potential for increased airborne levels would indicate if monitoring was needed.

- General Liquid Transfers. Although most operations are performed in hoods, periodically there may be a condition in which liquids are used or transferred outside of a hood then placed into a hood. Modeling of this activity for the chemicals identified in Section 6 will provide a general indication of the potential for elevated airborne concentrations.

\subsection{STORAGE CABINET MODELS}

For this evaluation, it was assumed that only one chemical contributes to the airborne concentrations released when the storage cabinets are opened. This was done to simplify the estimates and also to maximize the potential concentration. Both xylene and methylene chloride were modeled, xylene 
HNF-SD-SUP-LB-001, Rev. 0

because it is present in the cabinet and methylene chloride because it is a common chemical used and stored in this type of cabinet. For additional information on the storage cabinet models, see Appendix B.

\subsubsection{Storage Cabinet Generation Mode1}

The generation rate model (Equation 8-1) was adapted from the EPA drum filling model (EPA 1991). This model is frequently used to estimate airborne concentrations during tank truck or tank car loading and drumming operations. The concept behind this model is that when a substance is added to a container, an equal amount of volume will be displaced. In most cases the material added is liquid. In this storage cabinet case, the material added is air (i.e., when the cabinet is opened, air displaces the chemical until the odor fully dissipates). The fill rate was assumed to be the time necessary to remove all of the odor, either 5 or 15 minutes, based on worker estimates for odor dissipation. Because there were no obvious spills or open bottles in the cabinet, it was considered highly unlikely that the chemicals would reach saturation concentrations. The saturation factor is a modifier normally used to compensate for splashing liquids. For this activity it will be used to compensate for a nonsaturated atmosphere and is assumed to be $10 \%$. Additional information on the use of this model is provided in Appendix $B$.

Equation 8-1:

$$
\begin{aligned}
G_{x} & =\frac{r v P_{\text {avap }} f\left(M W_{x}\right)}{R T} \\
G_{x} & =\text { mass rate of contaminate released, } \mathrm{g} / \mathrm{min} \\
r & =\text { filling rate, } \mathrm{min}^{-1} \\
\nu & =\text { volume of cabinet }=0.75 \mathrm{~m}^{3} \\
P_{\text {avap }} & =\text { vapor pressure of contaminate, atm } \\
f & =\text { factor accounting for nonsaturated air }=10 \% \\
m w_{x} & =\text { molecular weight of contaminate, } \mathrm{g} / \mathrm{g}-\text { mole } \\
R & =8.205 x 10^{-5} \frac{\mathrm{m}^{3} \text { atm }}{\mathrm{g}-\text { mole } \mathrm{K}} \\
T & =\text { temp, } \mathrm{K} \text { (assumed room) }=298 \mathrm{~K}
\end{aligned}
$$

\subsubsection{Storage Cabinet Dispersion Mode1}

The models used for dispersion were: (1) the general ventilation model for a constant generation rate, well mixed room (AIHA and ACGIH 1996) and (2) rate of purging (ACGIH 1988). Both models are needed to properly address the airborne contamination levels.

The constant generation rate, well mixed room model (Equation $8-2$ ) is applicable until the time the vapors have been removed from the cabinet, either 5 or 15 minutes. The initial room concentration was assumed to be zero. Based on room $4 \mathrm{E}$, where the cabinets were previously stored, the room volume was calculated to be approximately $147 \mathrm{~m}^{3}$. The ventilation rate was 
calculated to be $37.1 \mathrm{~m}^{3} / \mathrm{min}$ based upon facility drawings. Per the Industrial Ventilation Manual (ACGIH 1988), an effective ventilation rate of $12.4 \mathrm{~m}^{3} / \mathrm{min}$ was used.

\section{Equation 8-2:}

$$
\begin{aligned}
& \qquad C_{x}=\frac{G_{x}}{Q^{\prime}}+\left(C_{x o}-\frac{G x}{Q^{\prime}}\right) e^{-\frac{Q^{\prime}(t-t)}{v}} \\
& G_{x}=\text { generation rate of contaminate, } \mathrm{g} / \mathrm{min} \\
& Q^{\prime}=\text { effective volumetric air flow rate, } \mathrm{m}^{3} / \mathrm{min} \\
& C_{x 0}=\text { initial room concentration }=0 \\
& t=\text { time of concern }=5,15 \text { minutes } \\
& t_{0}=\text { initial time }=0 \\
& v=\text { room volume }=147 \mathrm{~m}^{3}
\end{aligned}
$$

After the initial 5- or 15-minute time for the contaminate vapor to be removed from the cabinet, the concentration will be exponentially reduced as a purge based on ventilation rate and room volume (Equation 8-3).

\section{Equation 8-3:}

$$
\begin{aligned}
C_{f} & =C_{x} e^{-\frac{Q^{\prime}\left(t-t_{0}\right)}{v}} \\
C_{f} & =\text { Target concentration }=1.0 \mathrm{mg} / \mathrm{m}^{3} \\
C_{x} & =\text { Initial concentration, } \mathrm{mg} / \mathrm{m}^{3} \\
t-t_{0} & =\text { Time for reaching target concentration }
\end{aligned}
$$

A target concentration of $1.0 \mathrm{mg} / \mathrm{m}^{3}$ was chosen as a conservative value, not as an airborne limit. To determine the time necessary to meet the target concentration the purge equation was solved for $t$ (Equation 8-4).

\section{Equation 8-4:}

$$
t=t_{0}-\left(\frac{V}{Q^{\prime}} \ln \left(\frac{C_{f}}{C_{x}}\right)\right)
$$

The results of this modeling are described in Section 9.1 . 
HNF-SD-SUP-LB-001, Rev. 0

\subsection{DECONTAMINATION MODEL}

The decontamination in the hoods in Room 2B is often performed for extended periods. Chemicals (frequently nitric acid) are used to decontaminate materials (frequently lead). There is no known acceptable modeling for decontamination activities due to the difficulties in predicting generation rates of lead and nitric acid under these conditions and the airborne distribution opposite the direction of air flow. However, the Industrial Hygiene Ventilation Manual (ACGIH 1988) indicates exposures are likely acceptable based upon empirical data. The basis for this acceptability is described in Section 9.2.

\subsection{2-SA STANDARDS LABORATORY SOLIDS WEIGHING MODEL}

By comparing the airborne concentrations measured under a controlled study with conditions similar to those in the 222-SA Standards Laboratory, potential laboratory specific airborne concentrations can be predicted. A study was funded by the EPA to provide a model to estimate typical airborne particulate concentrations in the vicinity of industrial operations involving the handling of small volumes of solids (grams to kilograms of powders, granules, and flakes) (Cowherd et al. 1989). The materials evaluated were talc, sodium chloride, portland cement, and direct yellow 4 dye. These materials where chosen based upon their ability to create dust and were viewed as covering a wide range of "dust potential." In 1/2-hour tests, between 50 and $125 \mathrm{~kg}$ of each compound were transferred from one container to another. Each test split the original quantity to 28 to 43 different transfers. The airborne concentration was monitored for one hour. The average drop height of the chemicals was between 7.5 and $32 \mathrm{~cm}$, depending on the test and material. The air exchange rate was 4.5 air changes per hour. Additional information on this model is provided in Appendix $C$.

Comparing the EPA tests with the 222-SA Standards Laboratory, it was determined that the conditions for each critical parameter (e.g., drop height and air flow) were either more conservative in the 222-SA Laboratory complex or similar. The major difference was the weight. By comparing the weights, a rough order of magnitude airborne concentration potential could be determined using Equation 8-5.

Equation 8-5:

Assumed Airborne Concentration =

$\frac{\text { Average airborne concentration measured }}{\text { Average total transfer weight measured }} *$ Assumed weight transferred

\subsection{GENERAL CHEMICAL TRANSFER MODELS}

The airborne concentrations from pouring a chemical and leaving it outside of a hood could be significant. Past history, including monitoring results of methylene chloride usage (Section 7), indicate that there has been usage of some chemicals with measurable concentrations outside of hoods. The 
models used for this evaluation assume use outside of hoods. Exposure to fumes inside of hoods is not modeled because the hoods are designed to prevent high levels of airborne chemical concentration and are tested monthly to ensure that design parameters are met (Section 4.1). For these evaluations, two generation rate models and dispersion/exposure models were used. One approach assumed that airborne generation is primarily due to displaced vapors and the distribution follows a Gausian model to the person pouring the chemica1. The other approach assumed that evaporation is the generation driver and the general room ventilation model is the distribution path. When developing both approaches, methylene chloride was used as a test condition. Additional information on these models, using methylene chloride, is provided in Appendix D.

In both approaches, the following general parameters were assumed:

- The material of concern is poured from a container to a beaker, outside of the fume hood

- The material is allowed to remain outside of the hood for a period a time (e.g., 5 minutes)

- The room is similar in size to room 4E (approximately $150 \mathrm{~m}^{3}$ )

- The design ventilation rate is seven air changes per hour and the effective rate is $1 / 3$ of this based on ACGIH guidance (ACGIH 1988)

- Air flow is generally $30 \mathrm{ft} / \mathrm{min}$ based upon previous Pacific Northwest National Laboratory (PNL) studies (Stoetzel and Hickey 1990; Stoetzel and Cicotte 1992)

- Ideal gas laws are acceptable when other more specific data is not available.

These assumptions were chosen because they are either conservative measurements or common occurrences in most laboratories and provide quantifiable values for determining potential exposures.

\subsubsection{Displacement Vapors Generation Rate}

The displacement vapor generation model is based upon determining the saturation mole fraction of the chemical of concern, then determining the volume and mass released. In this case it was assumed that $200 \mathrm{~mL}$ was poured into a beaker containing residual liquid, displacing $200 \mathrm{~mL}$ of saturated volume. This model utilized Equations 8-6 through 8-8.

\section{Equation 8-6:}

$$
\text { Ideal gas assumed, } y_{a}=\frac{m^{3} \text { chemical }}{m^{3} \text { total }}
$$




$$
\begin{aligned}
& y_{a}=\text { Saturation mole fraction of chemical } \\
& y_{a}=\frac{P_{a}}{\text { Patm }} \\
& y_{a}=\frac{\text { Pressure of chemical } a}{760 \mathrm{~mm}} \\
& y_{a}=\frac{\text { moles chemical }}{\text { total moles }}
\end{aligned}
$$

Equation 8-7:

$$
\text { Volume released }{ }_{a}=(200 m l)\left(\frac{m^{3}}{10^{6} m l}\right)\left(y_{a}\right)
$$

Equation 8-8:

$$
\text { Mass released }=\frac{(\text { Volume released })(\text { molecular weight })}{\text { molar volume }}
$$

\subsubsection{Displacement Vapors Dispersion}

The displacement vapor dispersion model is based upon the Gaussian plume, as modified by de Nevers (1995) and the AIHA and ACGIH (1996) (Equation 8-9).

\section{Equation 8-9:}

$$
\begin{aligned}
C_{a} & =\frac{M}{8\left(\pi t D_{t}\right)^{\frac{3}{2}}} e^{-\frac{r^{2}}{(4 d, ~}} \\
C_{a} & =\text { Airborne concentration of chemical at time } t, \text { distance } r \\
m & =\text { mass released, } k g \\
t & =\text { time, seconds } \\
D_{t} & =\text { Turbulent dispersion coefficient }=1.67 \times 10^{-2} \frac{m^{2}}{g}, \text { based on AIHA } \wedge \text { ACGIH (1996) } \\
r & =\text { radius, assumed } 1 \mathrm{~m}
\end{aligned}
$$

\subsubsection{Evaporation Generation Mode1}

The evaporation generation model is a general equation developed by the EPA (EPA 1991) for spills that can be used to predict the evaporation rate of a liquid in a flowing air stream (Equation 8-10). In addition, the model takes into account the effect of changes in temperature, pressure, pool size, and air velocity. In general, the EPA equation assumes low concentrations of the evaporating solvent, as compared to the air concentration in the room. As 
a result, this equation may begin to show errors for strongly evaporating solvents, long pool lengths, or slow air wind velocities (EPA 1991).

For this evaluation, the limitations of the equation were considered acceptable due to the relatively short times that the material would be outside of the hood. In addition, lip effects from the beaker were assumed negligible. This also is a conservative estimate.

Equation 8-10:

Evap.Rate(mg/min)

$$
=(7560) \frac{\left(2.79 \times 10^{-3}\right)(M . W .)^{0.835}(V . P .)(A) \sqrt[4]{1 / M . W_{A}+1 / 29}}{T^{0.05}} \sqrt{\frac{v_{z}}{\Delta z p}}
$$

where:

$\begin{array}{ll}7,560= & \text { conversion from } 1 \mathrm{~b} / \mathrm{hr} \text { to } \mathrm{mg} / \mathrm{min} \\ M . W . & \text { molecular weight of evaporating liquid } \mathrm{A} \\ \mathrm{P} & =\text { overall pressure, atmospheres } \\ \Delta & =\text { length of pool along air flow, feet } \\ T & =\text { surface temperature of pool, Kelvin } \\ \mathrm{V} . \mathrm{P} & =\text { vapor pressure of substance } \mathrm{A} \text { (in. } \mathrm{Hg} \text { ) } \\ \mathrm{A} & =\text { liquid surface area, } \mathrm{ft}^{2} \\ \mathrm{~V}_{z}= & \text { velocity of air, } \mathrm{ft} / \mathrm{min}\end{array}$

This equation was tested by the EPA (1991) by comparing it to experimental data provided by Pace Laboratories (EPA 1991). In an extensive study using a specially-built apparatus, Pace Laboratories measured the evaporation rate of 15 different compounds at several different temperatures and air velocities, and fit the data against "power law" regression against molecular weight, vapor pressure, and air velocity, with generally good results. Pace Laboratories performed an overall regression analysis for all chemicais except the "low vapor pressure" alcohols (1-hexanol, 1-heptanol, and 2-octanol) and obtained the following equation (Equation 8-11).

\section{Equation 8-11:}

Evap. Rate $(\mathrm{mg} / \mathrm{min})=(7,560)(0.000237)(\mathrm{MW})(V P)\left(V_{z}^{0.625}\right)(A)$

where:

$$
\begin{array}{ll}
7,560= & \text { conversion from } 1 \mathrm{~b} / \mathrm{hr} \text { to } \mathrm{mg} / \mathrm{min} \\
\text { M.W. }= & \text { molecular weight of evaporating liquid A } \\
\text { V.P. }= & \text { vapor pressure of substance } A \text { (in. } \mathrm{Hg} \text { ) } \\
\mathrm{A}= & \text { liquid surface area, } \mathrm{ft}^{2} \\
\mathrm{v}_{2}= & \text { velocity of air, } \mathrm{ft} / \mathrm{min}
\end{array}
$$

\subsubsection{Evaporation Dispersion Mode1}

The dispersion model for this analysis was considered the same as that used for the storage cabinet (Section 8.2.2), i.e., a constant generation 
rate, well mixed room. As in the storage cabinet model, the dispersion model had to account for both the time outside of the hood (generation) and the purge time after the material was placed inside of the hood over varying times. The same equations were used (Equations 8-2 and 8-3) with the following exceptions: the buildup time was the time the chemical was outside of the hood and the purge time was the time the person was present in the room (maximum of 8 hours). 


\subsection{AIRBORNE CHEMICAL CONCENTRATION ESTIMATES}

This section describes the airborne chemical concentration estimates based upon the scenarios and models described in Section 8 . Additional information on these estimates is provided in Appendixes B through $F$.

\subsection{STORAGE CABINET ESTIMATE}

For this estimate, the storage cabinet in room $4 \mathrm{~L}$ was assumed to contain the vapors of either xylene or methylene chloride. When the door was opened, the vapors were released in either 5 or 15 minutes. The results of the storage cabinet airborne chemical concentration modeling, based on information provided in Appendix B, is presented in Table 9-1. As indicated, the maximum room airborne concentration can be high and the time to decrease concentrations to $1 \mathrm{mg} / \mathrm{m}^{3}$ could take up to 90 minutes. However, due to the short exposure times, 8-hour TWA limits will likely not be exceeded. Actual exposures and purge times are expected to be closer to typical values than worst case, but this cannot be confirmed until monitoring is completed. This model assumes good mixing in the entire room. Exposures to personnel standing in front of the cabinet while it is venting will be higher. Leaving the room is a good practice to minimize exposures.

Table 9-1. Storage Cabinet Airborne Chemical Concentration Estimates.

\begin{tabular}{|c|c|c|c|c|c|}
\hline \multirow{2}{*}{ Chemical Evaluated } & \multirow{2}{*}{$\begin{array}{c}\text { Generation } \\
\text { Rate } \\
\text { (g/min) }\end{array}$} & \multicolumn{2}{|c|}{ Worst Case ${ }^{1}$} & \multicolumn{2}{|c|}{ Typical $^{2}$} \\
\hline & & $\underset{\text { Conc }}{\operatorname{Max}}$ & $\begin{array}{c}\text { Time to } \\
\text { Reach } \\
1 \mathrm{mg} / \mathrm{m}^{3} \\
\text { (minutes) } \\
\end{array}$ & $\begin{array}{l}\text { Max. } \\
\text { Conc. } \\
\left(\mathrm{mg} / \mathrm{m}^{3}\right)\end{array}$ & $\begin{array}{c}\text { Time to } \\
\text { Reach } \\
1 \mathrm{mg} / \mathrm{m}^{3} \\
\text { (minutes) } \\
\end{array}$ \\
\hline $\begin{array}{l}\text { Xylene with a } 15 \text { min } \\
\text { release time }\end{array}$ & 0.26 & 15 & 47 & 6.8 & 23 \\
\hline $\begin{array}{l}\text { Methylene chloride } \\
\text { with a } 15 \text { min } \\
\text { release time }\end{array}$ & 8.02 & 464 & 88 & 211 & 36 \\
\hline $\begin{array}{l}\text { Methylene chloride } \\
\text { with a } 5 \text { min release } \\
\text { time }\end{array}$ & 23.9 & 663 & 82 & 462 & 29 \\
\hline
\end{tabular}

15 air changes per hour estimated per ACGIH criteria

215 air changes per hour calculated for room 4E

\subsection{DECONTAMINATION ESTIMATES}

Estimates of lead and nitric acid airborne concentrations in the room $2 \mathrm{~B}$ decontamination station can be assumed low due to the strict engineering design requirements (Section 4.1 ), but there are no known models available to adequately predict the generation rate and subsequent concentrations. Because there are no adequate models, periodic monitoring for lead and nitric acid should be performed in room 2B. This monitoring is scheduled. 
Airborne concentrations outside of hoods are a function of both the airflow into the hood and the general ventilation pattern. The ACGIH Ventilation Manual (ACGIH 1988) cites a study performed by Caplan and Knutson (1978) that demonstrated concentrations outside of hoods can be maintained low if hoods are adequately designed. With a good air supply system inside the hood and outside the hood, a tracer gas release inside of the hood of at least $8 \mathrm{~L} / \mathrm{min}$ resulted in concentrations outside of the hood below $0.1 \mathrm{ppm}$ and usually below $0.01 \mathrm{ppm}$. These results were with an air flow into the hood of $50 \mathrm{lfm}$. If the air flow outside of the hood was poor, concentrations outside of the hood were higher, even if the face velocity was increased to $1501 \mathrm{fm}$. This relationship between the general room air and the air flow cannot be readily modeled.

Decontamination of glassware and lead shielding performed inside of the hoods in room 2B may release particles greater than fume size, which will have a greater potential for escaping the hood. Laboratory hoods are designed primarily to capture fumes. Larger particles could be released from the action of scrubbing materials. However, it is likely that these materials are captured. A capture velocity of 100 to $2001 \mathrm{fm}$ is recommended for activities that release materials at low velocity, such as intermittent container filling (ACGIH 1988). Periodic airborne chemical monitoring would help demonstrate adequate design and proper decontamination methods.

\subsection{2-SA STANDARDS LABORATORY SOLIDS WEIGHING ESTIMATES}

Exposures to solids in the 222-SA Standards Laboratory are minimal and should not be further evaluated. A study funded by the EPA provided a model to estimate airborne concentrations of a variety of materials when small volumes of these materials were transferred over a 30-minute time (Cowherd et a). 1989). As indicated in Section 8.4 and Appendix C, the conditions in the 222-SA Standards Laboratory are at least equal, if not more conservative, than the test conditions.

Results of the comparison of the 222-SA Laboratory complex and the EPA study indicate that the worst case maximum estimated 1 -hour airborne concentration is $1 \mathrm{mg} / \mathrm{m}^{3}$ and the large majority of weighing activities would result in concentrations equal to or less than $0.01 \mathrm{mg} / \mathrm{m}^{3}$ (Table $\left.9-2\right)$. No chemicals that could be weighed have exposure 1 imits of $0.01 \mathrm{mg} / \mathrm{m}^{3}$. The compound with the lowest known exposure level is cadmium sulfide $\left(0.1 \mathrm{mg} / \mathrm{m}^{3}\right)$. This product is never weighed in large quantities. In addition, the limits are for an 8-hour exposure, thus the 8-hour concentration would be significantly lower than those identified in Table 9-2. 
HNF-SD-SUP-LB-001, Rev. 0

Table 9-2. Evaluation of 222-SA Standards Laboratory Potential Airborne Concentration.

\begin{tabular}{|l|c|c|c|c|}
\hline \multicolumn{3}{|c|}{ Cowherd et al. (1989) Data' } & \multicolumn{2}{|c|}{ 222-SA Standards Laboratory } \\
Extrapolation
\end{tabular}

1 Dust Inhalation Exposures from the Handling of 5 ma 77 Volumes of Powders

$2 \quad$ (Cowherd et al. 1989)

A11 measurements within $1 \%$ of average.

\subsection{GENERAL CHEMICAL TRANSFER ESTIMATES}

If certain chemicals are used outside of hoods, the airborne concentrations could be significant and exceed exposure limits. Past usage of some of these chemicals indicates that exposure will occur if the chemicals are present outside of a hood (Section 7). Because most chemicals, including a1l chemicals that have been identified as having a high airborne concentration potential, are reportedly used only inside of hoods, the results in this section should be used primarily to indicate potential concentrations if normal laboratory practices and procedures are not followed.

\subsubsection{Chemicals Evaluated}

The chemicals evaluated were those that indicated high airborne concentration potential based upon comparing: (1) the molecular weight, vapor pressure, and applicable airborne limits (Section 6.2) and (2) many of the frequently used chemicals (Section 6.1) (Table 9-3). In some cases, chemicals fit into both categories. Airborne limits for these chemicals are provided in Table 9-3. In some cases airborne limits were derived from ACGIH Criteria (ACGIH 1996). 
Table 9-3. Chemicals of Concern - Airborne Limits.

\begin{tabular}{|c|c|c|c|c|}
\hline Chemical Name & $\begin{array}{c}\text { 8-hr TWA }{ }^{(1)} \\
\left(\mathrm{mg} / \mathrm{m}^{3}\right)\end{array}$ & $\begin{array}{c}\text { 15-min STEL } \\
(2) \\
\left(\mathrm{mg} / \mathrm{m}^{3}\right)\end{array}$ & $\begin{array}{l}\text { Ceiling }{ }^{(3)} \\
\left(\mathrm{mg} / \mathrm{m}^{3}\right)\end{array}$ & IDLH $\left(\mathrm{mg} / \mathrm{m}^{3}\right)$ \\
\hline High Potential Airbome / Frequent Use & e, & 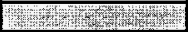 & 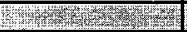 & 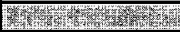 \\
\hline Hydrochloric Acid (38 wt \%) & Not Applicable & Not Applicable & $7^{(8)}$ & 70 \\
\hline Methylene Chloride & $174^{(8)}$ & Not Used ${ }^{(9)}$ & $3,480^{(5)}$ & 8,119 \\
\hline High Potential Airbome & 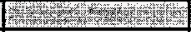 & 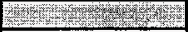 & 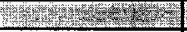 & 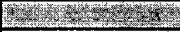 \\
\hline Bromine & $0.7^{(5)}$ & $1.3^{(8)}$ & $3.5^{(7)}$ & 19.92 \\
\hline Benzene & $3.25^{(5)}$ & $16^{(5)}$ & $16.25^{(7)}$ & 1,625 \\
\hline Ammonium Hydroxide $\left(27 w^{\circ} \%\right)^{(9)}$ & $17^{(8)}$ & $35^{(8)}$ & $35^{(8)}$ & 213 \\
\hline Hydrofluoric Acid (51 wt\%) & $2.49^{(5)}$ & Not Applicable & $2.5^{(8)}$ & 24.9 \\
\hline Ammonium Hydroxide $(11 \mathrm{wt} \%)^{(9)}$ & $17^{(8)}$ & $35^{(8)}$ & $35^{(8)}$ & 213 \\
\hline Epichlorohydrin & $7.6^{(8)}$ & $22.8^{(6)}$ & $38^{(7)}$ & 288 \\
\hline Hydrogen Peroxide (30 wt \%) & $1.4^{(5)}$ & $4.2^{(6)}$ & $7.0^{(7)}$ & 105 \\
\hline Pyridine & $15^{(5)}$ & $45^{(6)}$ & $75^{(7)}$ & 3,290 \\
\hline n-Hexane & $176^{(8)}$ & $528^{(6)}$ & $888^{(7)}$ & 3,938 \\
\hline Frequent Use & Hething & Qth & 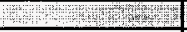 & 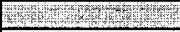 \\
\hline Nitric Acid $(70 w i \%)$ & $5^{(5)}$ & $15^{(6)}$ & $25^{(7)}$ & 65.5 \\
\hline Insta Gel (1,2,4-trimethylbenzene) & $125^{(5)}$ & 175 & $625^{(7)}$ & NA \\
\hline Ethyl Alcohol & $1,880^{(8)}$ & $5,640^{(6)}$ & $9,400^{(7)}$ & 6,336 \\
\hline
\end{tabular}

(1) 8-hour Time Weighted Average

(2) 15-minute Averaged Short Term Exposure Limit

(3) Ceiling Value that should never be exceeded

(4) Ammonium Hydroxide as ammonia

(5) OSHA

(6) Based on 3 times 8-hr TWA Value, per. ACGIH Guidance

(7) Based on 5 times 8 -hr TWA value, per. ACGIH Guidance

(8) ACGIH

(9) 5 minute STEL is availabie but not practicable for lab situation 


\subsubsection{Displacement Vapors Airborne Concentration Estimates}

The airborne concentration estimates from calculating the mass resulting from a displacement of saturated vapor and subsequent dispersion based on Gaussian distribution was low, was significantly less than that predicted by evaporation, and was no longer considered a major contributor to airborne concentrations. However, for chemicals with low airborne limits (e.g., benzene, bromine, and hydrofluoric acid), particularly if short-term exposure limits (STELs) or ceiling levels are involved, even this release is sufficient to cause potential exceedance of the 1 imit. If volumes significantiy greater than $200 \mathrm{~mL}$ are poured, this pathway could be reevaluated. In addition, this may be a prime pathway for very low vapor pressure chemicals with extremely low exposure limits such as mercury.

Table 9-4 provides the maximum concentration results estimated from displacement.

Table 9-4. Maximum Airborne Concentrations Estimated from Displacement.

\begin{tabular}{|c|c|}
\hline Chemical Name & $\begin{array}{c}\text { Maximum Concentration } \\
\text { Due to Displacement } \\
\left(\mathrm{mg} / \mathrm{m}^{3}\right)\end{array}$ \\
\hline \multicolumn{2}{|l|}{ High Potential Airborne/Frequent Use } \\
\hline Hydrochloric Acid $(38 w t \%)^{(2)}$ & 6.09 \\
\hline Methylene Chloride & 23.6 \\
\hline \multicolumn{2}{|l|}{ High Potential Airborne } \\
\hline Bromine & 21.8 \\
\hline Benzene & 4.65 \\
\hline Ammonium Hydroxide $(27 w t \%)^{(3)}$ & 13.27 \\
\hline Hydrofluoric Acid (51 wt\%) & 6.09 \\
\hline Ammonium Hydroxide $(11 \text { wt } \%)^{(3)}$ & 2.46 \\
\hline Epichlorohydrin & 0.95 \\
\hline Hydrogen peroxide (30 wt\%) & 0.13 \\
\hline Pyridine & 1.01 \\
\hline n-Hexane & 8.49 \\
\hline \multicolumn{2}{|l|}{ Frequent Use } \\
\hline Nitric Acid (70 wt\%) & 0.15 \\
\hline Insta Gel $(1,2,4$-trimethylbenzene $)$ & 0.29 \\
\hline Ethyl alcohol & 1.61 \\
\hline
\end{tabular}

(1) Assuming displacement of $200 \mathrm{ml}$ of saturated vapor with exposure at 1 meter.

(2) Hydrochloric acid results highly dependent on concentration. See Section 9.4.3.1.

(3) Ammonium Hydroxide as Ammonia. 
HNF-SD-SUP-LB-001, Rev. 0

Figure 9-1 provides the concentration curve for methylene chloride. All other concentration curves are similar. These maximum values are achieved within seconds of pouring. The average levels would be much lower.

\subsubsection{Evaporation Airborne Concentration Estimates}

The evaporation rates can be significant, based on the EPA theoretical model and Pace Laboratories empirical model (EPA 1991). As indicated in Table 9-5, the EPA model is typically a factor of approximately two higher than the Pace Laboratories model. Because this higher value is the value used by EPA for airborne concentration assessments, it is also the value used in this evaluation.

9.4.3.1 Results. The airborne concentration profile is indicated by a sharp rise until the chemical is placed in a hood. This is demonstrated for methylene chloride in Figure 9-2. As expected, the longer the chemical is outside of the hood, the higher the maximum (Figure 9-3) and average concentrations (Figure 9-4). Figures for each of the chemicals of concern for typical ventilation rate (seven air changes per hour) are provided in Appendix $E$ (maximum concentrations) and $F$ (average concentrations). Table 9-6 indicates the times necessary for concentrations to reach airborne limits. Table 9-7 provides equilibrium concentrations and times to reach equilibrium concentrations.

Exposure to hydrochloric acid is highly dependent on the solution concentration of the hydrochloric acid solution. Calculations of the maximum airborne concentration of hydrochloric acid in the room were performed for solution concentrations of 30 wt\% through 38 wt\% HCl $(9.4 \mathrm{M}$ through $12.4 \mathrm{M})$. The results of these calculations, shown in Figure 9-5, indicate that a solution concentration of $38 \mathrm{wt} \%$ will cause the airborne concentration of airborne $\mathrm{HCl}$ in the room to exceed the immediately dangerous to life or health (IDLH) level in a very short time, whereas a solution concentration of $30 \mathrm{wt} \%$ will cause the airborne concentration in the room to never reach the ceiling exposure (CEIL) level.

As can be seen from Table 9-6, airborne limits can be exceeded within relatively short time periods for many of the chemicals of concern. This evidence supports the laboratory practice of using most chemicals only in hoods.

Actual concentrations, and times to reach airborne limits, will vary from those predicted. The model validation provided in Section 10.1 indicates that actual exposures will likely be closer to the typical values than the worst case values.

9.4.3.2 Minimum Volumes. Activities that use very small liquid quantities outside of hoods may never exceed airborne limits due to lack of available material. By multiplying the shortest time necessary to reach an airborne 1 imit by the evaporation rate, a minimum volume required to reach the 1 imit is ident ified (Table 9-8). Use of volumes less than this should not require monitoring unless usage conditions change. Table 9-8 indicates that only smal1 volumes of several chemicals could result in exceeding limits if left outside of hoods. Large volumes are necessary for methylene chloride. 
HNF-SD-SUP-LB-001, Rev. 0

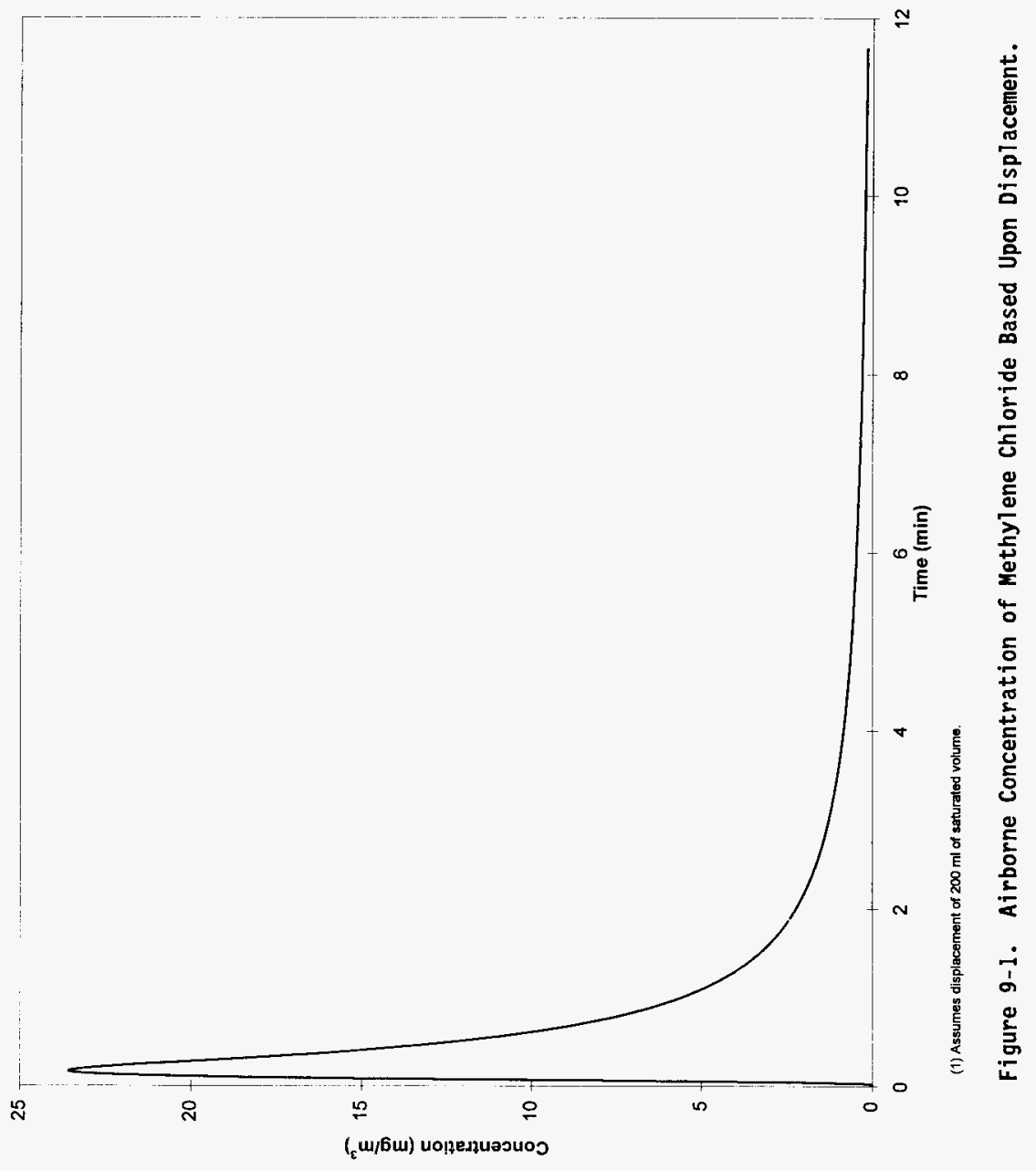


Table 9-5. Chemicals of Concern Evaporation Rates.

\begin{tabular}{|c|c|c|c|c|}
\hline Chemical Name & $\begin{array}{l}\text { Molecular } \\
\text { Weight }\end{array}$ & $\begin{array}{l}\text { Vapor } \\
\text { Pressure } \\
(\mathrm{mm} \mathrm{Hg}) \\
\end{array}$ & $\begin{array}{l}\text { EPA Theoretical } \\
\text { Evaporation }^{(1)(2)} \\
\text { (mg/min) }\end{array}$ & $\begin{array}{c}\text { PACE Empirical } \\
\text { Evaporation }^{(1)(2)} \\
\text { (mg/min) }^{2}\end{array}$ \\
\hline High Potential Airborne / Frequent Use & 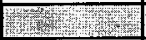 & 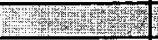 & Ty & 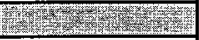 \\
\hline Hydrochloric Acid $(38 \mathrm{wt} \%)^{(3)}$ & 36.5 & 210 & 1760 & 747 \\
\hline Methylene Chloride & 84.9 & 350 & 5520 & 2900 \\
\hline High Potential Airbome & 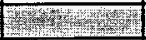 & Why & 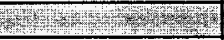 & 2. \\
\hline Bromine & 159.8 & 172 & 4460 & 2680 \\
\hline Benzene & 78.1 & 75 & 1110 & 571 \\
\hline Ammonium Hydroxide $(27 \mathrm{wt} \%)^{(4)}$ & 35.06 & 477 & 3880 & 1631 \\
\hline Hydrofluoric Acid (51 wt\%) & 20 & 32 & 180 & 60 \\
\hline Ammonium Hydroxide $(11 \mathrm{wt} \%)^{(4)}$ & 35.06 & 88 & 720 & 300 \\
\hline Epichlorohydrin & 92.5 & 13 & 219 & 117 \\
\hline Hydrogen Peroxide $(30 \mathrm{wt} \%)$ & 34 & 5 & 39.8 & 16.6 \\
\hline Pyridine & 79.1 & 16 & 239 & 123 \\
\hline $\mathrm{n}$-Hexane & 86.2 & 124 & 1980 & 1040 \\
\hline Frequent Use & 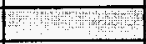 & का & 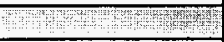 & 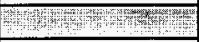 \\
\hline Nitric Acid $(70 \mathrm{wt} \%)$ & 63 & 3 & 38 & 18 \\
\hline Insta Gel (1,2,4-trimethylbenzene) & 120.2 & 3 & 62 & 35.2 \\
\hline Ethyl Alcohol & 46.1 & 44 & 438 & 198 \\
\hline
\end{tabular}

(1) Based on EPA 1991 equations as described in Section 8.5.3

(2) Assuming

5.5 in. diameter container

$30 \mathrm{ft} / \mathrm{min}$ airflow over container

(3) Hydrochloric acid results highly dependent on concentration. See Section 9.4.3.1

(4) Ammonium Hydroxide as Ammonia. 
250

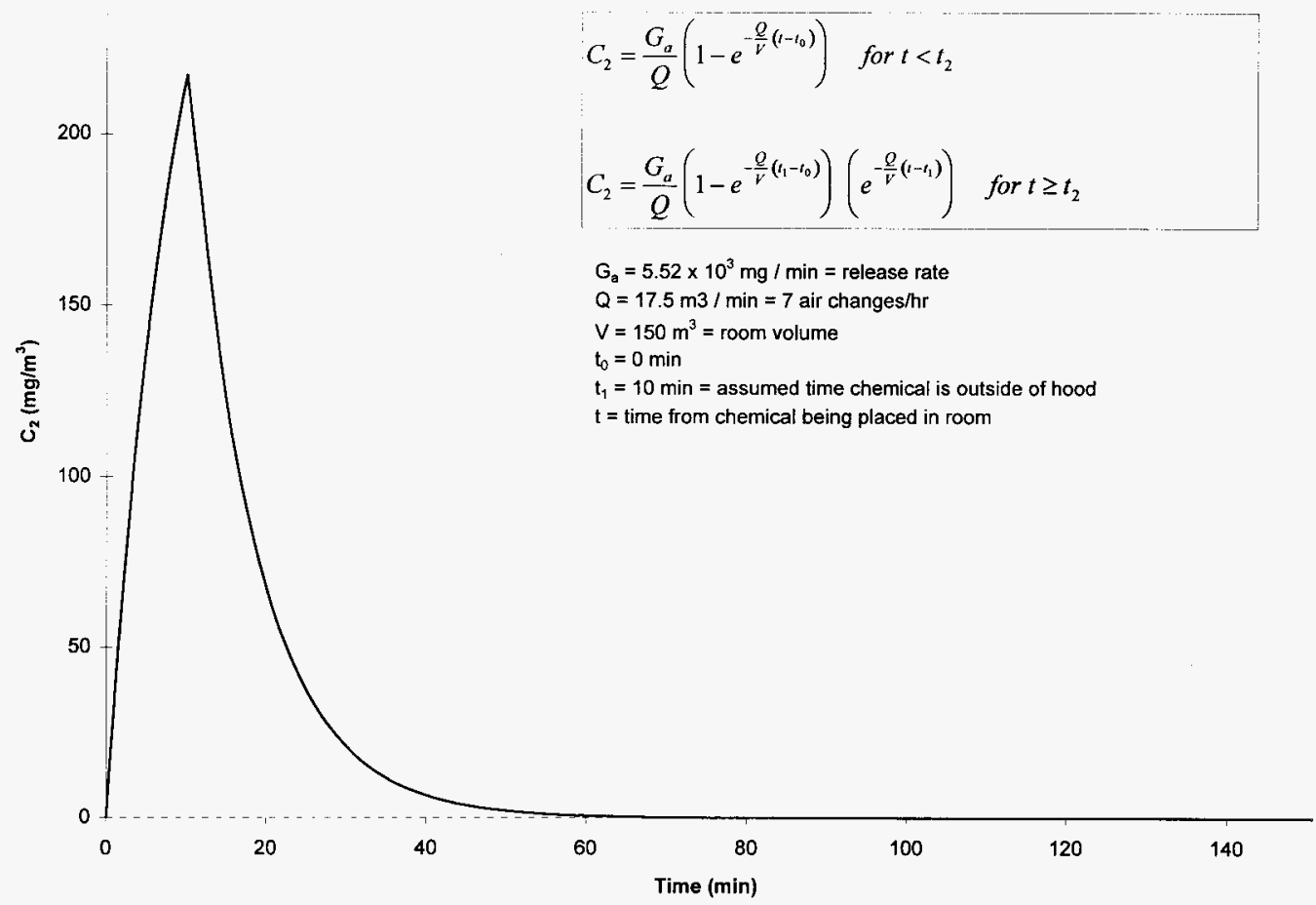

Figure 9-2. Instantaneous Concentration of Methylene Chloride in Room. 


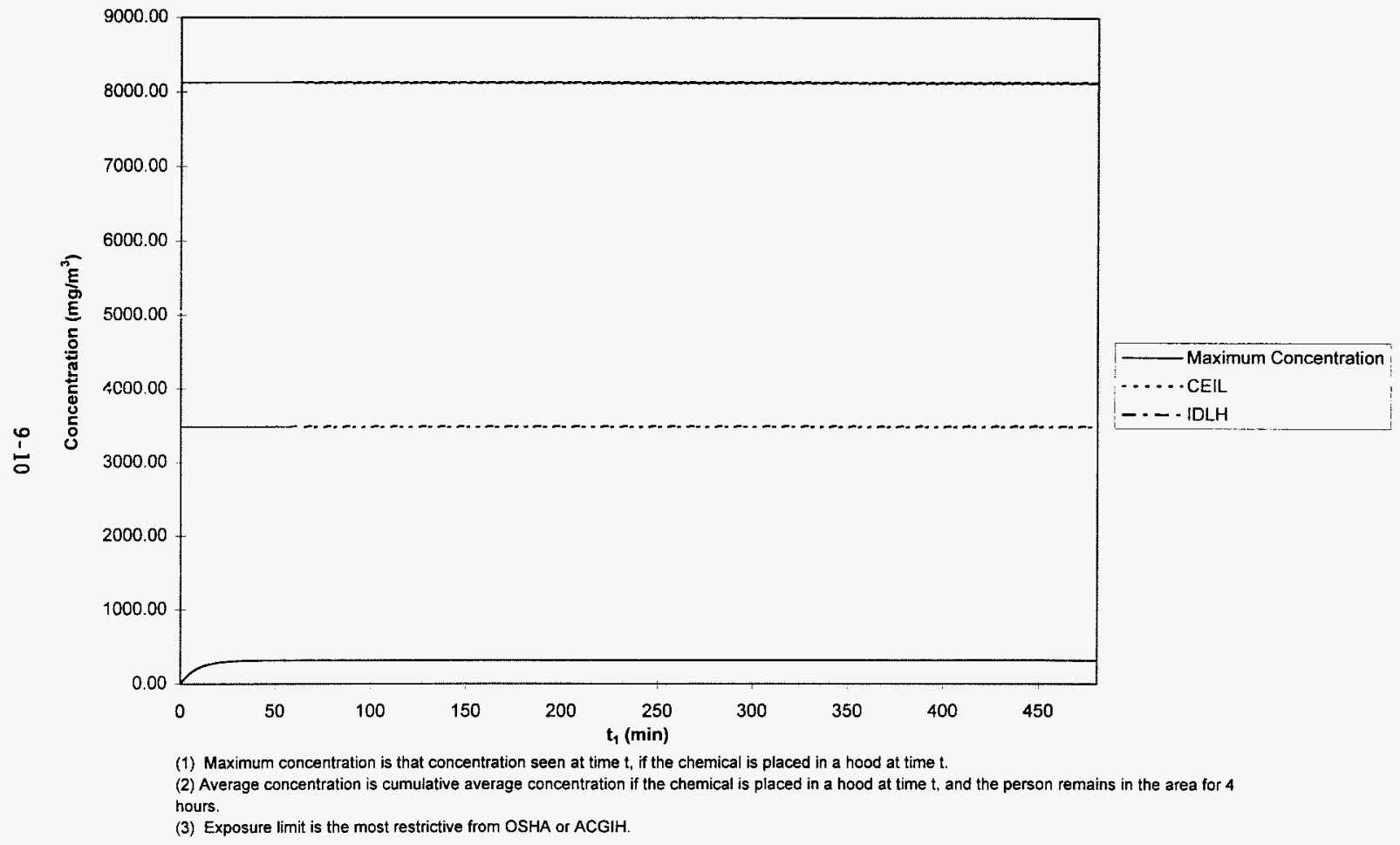

Figure 9-3. Maximum Concentration of Methylene Chloride in Room. 


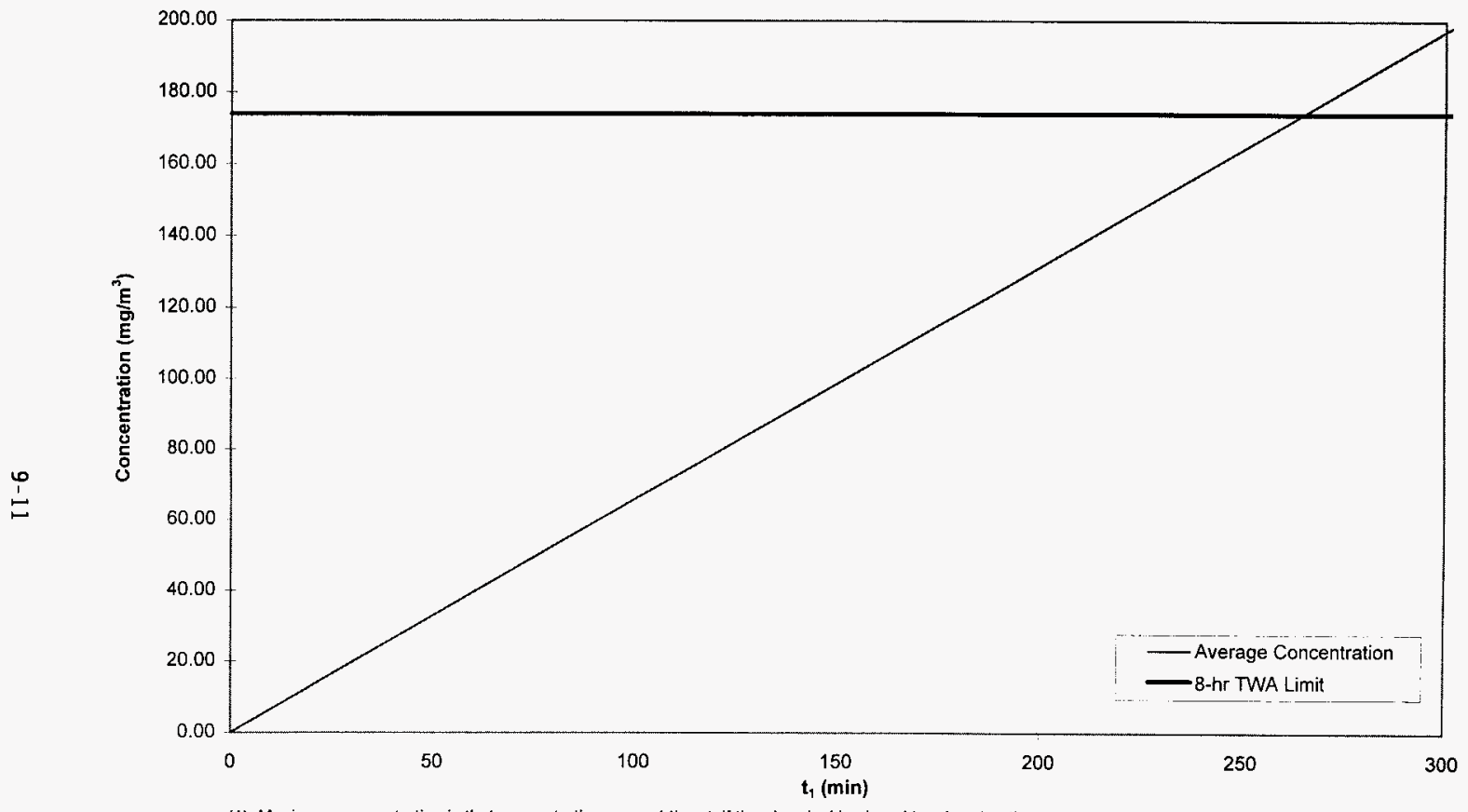

(1) Maximum concentration is that concentration seen at time $t$, if the chemical is placed in a hood at time t

(2) Average concentration is cumulative average concentration if the chemical is placed in a hood at time $t$, and the person remains in the area for 4 hours.

(3) Exposure limit is the most restrictive from OSHA or ACGIH.

Figure 9-4. Averaged Concentration of Methylene Chloride in Room. 
Table 9-6. Chemicals of Concern - Times to Reach Airborne Limits.

\begin{tabular}{|c|c|c|c|c|c|c|c|c|}
\hline \multirow{3}{*}{ Chemical Name } & \multicolumn{4}{|c|}{ Worst Case $^{(1)}$} & \multicolumn{4}{|c|}{ Typical $^{(2)}$} \\
\hline & \multicolumn{4}{|c|}{ Airborne Limit Time ${ }^{(3)}$ (min) } & \multicolumn{4}{|c|}{ Airborne Limit Time ${ }^{(3)}$ (min) } \\
\hline & 8-hr TWA & STEL & CEIL & IDLH & 8-hr TWA & STEL & CEIL & IDLH \\
\hline High Potential Alnborne / Frequent Use & 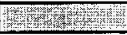 & 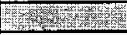 & 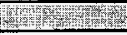 & 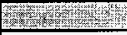 & 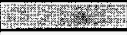 & 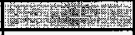 & 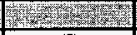 & 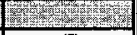 \\
\hline Hydrochloric Acid $\left(38 \mathrm{wt}^{\%}\right)^{(5)}$ & NA & NA & (5) & (5) & NA & NA & (5) & (5) \\
\hline Methylene Chloride & $85 \min$ & NA & $>8 \mathrm{hr}$ & $>8 \mathrm{hr}$ & $260 \mathrm{~min}$ & NA & $>8 \mathrm{hr}$ & $>8 \mathrm{hr}$ \\
\hline High Potential Airborne & 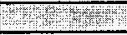 & 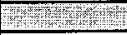 & 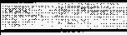 & 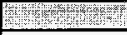 & 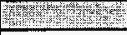 & 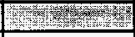 & 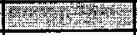 & 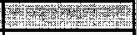 \\
\hline Bromine & $<1 \mathrm{~min}$ & $<1 \mathrm{~min}$ & $<1 \min ^{(4)}$ & $<1 \min$ & $1 \mathrm{~min}$ & $<1 \min$ & $<1 \min ^{(4)}$ & $<1 \min$ \\
\hline Benzene & $8 \mathrm{~min}$ & $2 \min$ & $2 \min ^{\langle 4\rangle}$ & $>8 \mathrm{hr}$ & $24 \mathrm{~min}$ & $2 \min$ & $2 \min ^{(4)}$ & $>8 \mathrm{hr}$ \\
\hline Ammonium Hydroxide $\left(27 w^{t} \%\right)^{\langle 6\rangle}$ & $12 \mathrm{~min}$ & $1 \mathrm{~min}$ & $1 \mathrm{~min}$ & $9 \min$ & $37 \mathrm{~min}$ & $1 \mathrm{~min}$ & $1 \mathrm{~min}$ & $27 \mathrm{~min}$ \\
\hline Hydrofluoric Acid (51 wt\%) & $40 \min$ & NA & $2 \mathrm{~min}$ & $40 \mathrm{~min}$ & $115 \mathrm{~min}$ & NA & $2 \min$ & $>8 \mathrm{hr}$ \\
\hline Ammonium Hydroxide $(11 \mathrm{w} \%)^{(6)}$ & $65 \mathrm{~min}$ & $8 \mathrm{~min}$ & $8 \mathrm{~min}$ & $>8 \mathrm{hr}$ & $195 \mathrm{~min}$ & $16 \min$ & $16 \mathrm{~min}$ & $>8 \mathrm{hr}$ \\
\hline Epichlorohydrin & $95 \mathrm{~min}$ & $24 \min ^{(4)}$ & $>8 \mathrm{hr}^{(4)}$ & $>8 \mathrm{hr}$ & $290 \mathrm{~min}$ & $>8 \mathrm{hr}^{(4)}$ & $>8 \mathrm{hr}^{(4)}$ & $>8 \mathrm{hr}$ \\
\hline Hydrogen Peroxide ( $30 w^{\%} \%$ ) & $95 \mathrm{~min}$ & $24 \min ^{(4)}$ & $>8 \mathrm{hr}^{(4)}$ & $>8 \mathrm{hr}$ & $295 \min$ & $>8 \mathrm{hr}^{(4)}$ & $>8 \mathrm{hr}^{(4)}$ & $>8 \mathrm{hr}$ \\
\hline Pyridine & $175 \min$ & $>8 \mathrm{hr}^{(4)}$ & $>8 \mathrm{hr}^{(4)}$ & $>8 \mathrm{hr}$ & $>8 \mathrm{hr}$ & $>8 \mathrm{hr}^{(4)}$ & $>8 \mathrm{hr}^{(4)}$ & $>8 \mathrm{hr}$ \\
\hline n-Hexane & $245 \mathrm{~min}$ & $>8 \mathrm{hr}^{(4)}$ & $>8 \mathrm{hr}^{(4)}$ & $>8 \mathrm{hr}$ & $>8 \mathrm{hr}$ & $>8 \mathrm{hr}^{(4)}$ & $>8 \mathrm{hr}^{(4)}$ & $>8 \mathrm{hr}$ \\
\hline Frequent Use & 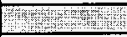 & 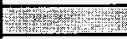 & 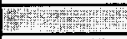 & 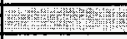 & 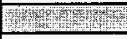 & 4 & 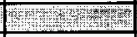 & (6) \\
\hline Nitric Acid (70 wt\%) & $370 \mathrm{~min}$ & $>8 \mathrm{hr}$ & $>8 \mathrm{hr}^{(4)}$ & $>8 \mathrm{hr}$ & $>8 \mathrm{hr}$ & $>8 \mathrm{hr}$ & $>8 \mathrm{hr}^{(4)}$ & $>8 \mathrm{hr}$ \\
\hline Insta Gel (1,2,4-trimethylbenzene) & $>8 \mathrm{hr}$ & $>8 \mathrm{hr}$ & $>8 \mathrm{hr}^{(4)}$ & NA & $>8 \mathrm{hr}$ & $>8 \mathrm{hr}$ & $>8 \mathrm{hr}^{(4)}$ & NA \\
\hline Ethyl Alcohol & $>8 \mathrm{hr}$ & $>8 \mathrm{hr}^{(4)}$ & $>8 \mathrm{hr}$ & $>8 \mathrm{hr}$ & $>8 \mathrm{hr}$ & $>8 \mathrm{hr}^{(4)}$ & $>8 \mathrm{hr}$ & $>8 \mathrm{hr}$ \\
\hline
\end{tabular}

(1) Room ventillation rate of $5.83 \mathrm{~m}^{3} / \mathrm{min}$ (2.3 air changes / hour)

(2) Room ventillation rate of $17.5 \mathrm{~m}^{3} / \mathrm{min}$ (7 air changes / hour).

(3) Time required to reach aisbome limit. See Table 93 for limits.

(4) Using estimated limit based on ACGIH guidance (See Table 9-3)

(5) Hydrochloric acid results highly dependent on concentration. See Section 9.4.3.1

(6) Ammonium Hydroxide as Ammonia. 
Table 9-7. Chemicals of Concern - Equilibrium Concentrations.

\begin{tabular}{|c|c|c|c|c|}
\hline \multirow[t]{2}{*}{ Chemical Name } & \multicolumn{2}{|c|}{ Worst Case Ventillation ${ }^{(1)}$} & \multicolumn{2}{|c|}{ Typical Ventillation ${ }^{(2)}$} \\
\hline & $\begin{array}{c}\text { Equilibrium } \\
\text { Concentration }\left(\mathrm{mg} / \mathrm{m}^{3}\right)\end{array}$ & $\begin{array}{l}\text { Time to Reach } \\
\text { Equilibrium (min) }\end{array}$ & $\begin{array}{c}\text { Equilibrium } \\
\text { Concentration }\left(\mathrm{mg} / \mathrm{m}^{3}\right)\end{array}$ & $\begin{array}{l}\text { Time to Reach } \\
\text { Equilibrium (min) }\end{array}$ \\
\hline High Potential Airborne / Frequent Use & 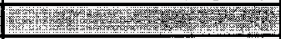 & 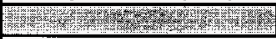 & 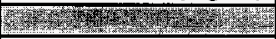 & 1010 \\
\hline Hydrochloric Acid $(38 \mathrm{wt} \%)^{(3)}$ & 302 & 270 & 101 & 95 \\
\hline Methylene Chloride & 947 & 295 & 315 & 100 \\
\hline High Potential Airborne & (3) & 5 & 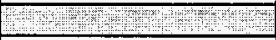 & 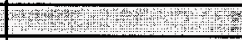 \\
\hline Bromine & 765 & 320 & 255 & 105 \\
\hline Benzene & 190 & 255 & 63 & 85 \\
\hline Ammonium Hydroxide $\left(27 \mathrm{w}^{\%} \%\right)^{(4)}$ & 222 & 90 & 665 & 295 \\
\hline Hydrofluoric Acid (51 wt\%) & 31 & 210 & 10 & 85 \\
\hline Ammonium Hydroxide $(11 \mathrm{w} \%)^{(4)}$ & 41 & 75 & 123 & 270 \\
\hline Epichlorohydrin & 38 & 215 & 13 & 70 \\
\hline Hydrogen Peroxide $(30 \mathrm{w} \%)$ & 7 & 185 & 2 & 47 \\
\hline Pyridine & 41 & 215 & 14 & 75 \\
\hline$n$-Hexane & 340 & 280 & 113 & 85 \\
\hline Frequent Use & 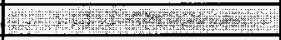 & 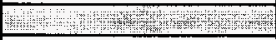 & Fin & 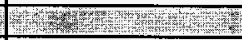 \\
\hline Nitric Acid $(70 \mathrm{wt} \%)$ & 7 & 175 & 2 & 48 \\
\hline Insta Gel (1,2,4-trimethylbenzene) & 11 & 190 & 4 & 80 \\
\hline Ethyl Alcohol & 75 & 240 & 25 & 70 \\
\hline
\end{tabular}

(1) Room ventillation rate of $5.83 \mathrm{~m}^{3} / \mathrm{min}$ ( 2.3 air changes / hour).

(2) Room ventillation rate of $17.5 \mathrm{~m}^{3} / \mathrm{min}$ (7 air changes / hour)

(3) Hydrochioric acid results highly dependent on concentration. See Section 9.4.3.1

(4) Ammonium Hydroxide as Ammonia. 
HNF-SD-SUP-LB-001, Rev. 0

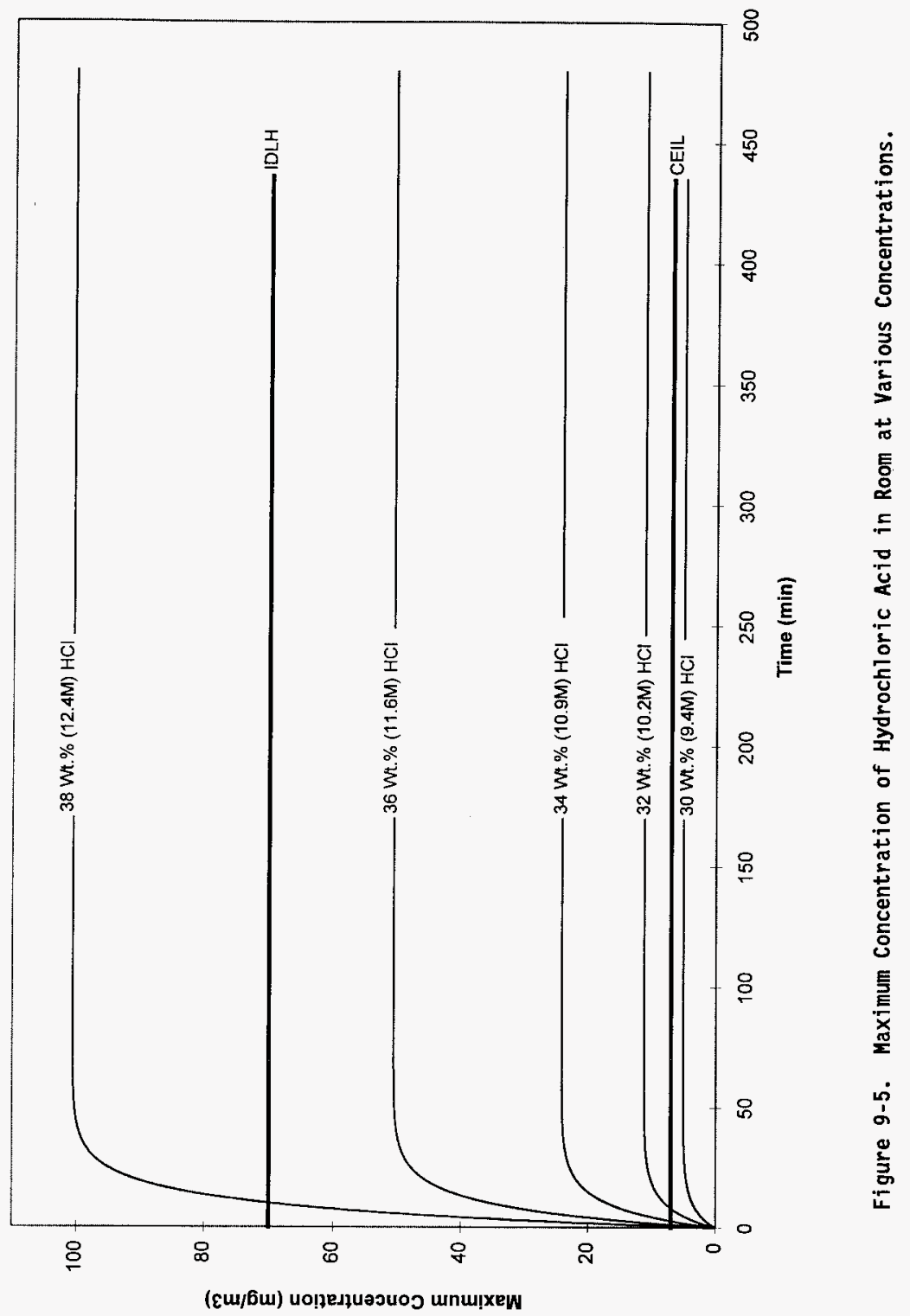


Table 9-8. Chemicals of Concern - Volumes of Chemical Required.

\begin{tabular}{|c|c|c|c|c|}
\hline \multirow{3}{*}{ Chemical Name } & \multicolumn{4}{|c|}{ Volume of Chemical Required in Limiting Airborne Level } \\
\hline & \multicolumn{2}{|c|}{ Worst Case Ventillation ${ }^{(1)}$} & \multicolumn{2}{|c|}{ Typical Ventillation ${ }^{(2)}$} \\
\hline & Limiting Factor & Volume (ml) & Limiting Factor & Volume (ml) \\
\hline High Potential Airbornel Frequent Use & 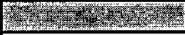 & 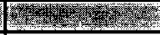 & 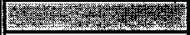 & 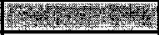 \\
\hline Hydrochloric Acid $\left(38 w t^{\circ}\right)^{(4)}$ & CEIL & 2.2 & \begin{tabular}{|c|} 
CEIL \\
\end{tabular} & 2.2 \\
\hline Methylene Chloride & 8-hr TWA & 247 & 8-hr TWA & 755 \\
\hline High Potential Airborne & Fits & 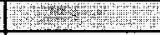 & 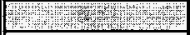 & 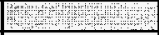 \\
\hline Bromine & All & 1.2 & \begin{tabular}{|c|} 
STEL \\
\end{tabular} & \begin{tabular}{|c|}
1.2 \\
\end{tabular} \\
\hline Benzene & STEL, CEIL & 1.3 & STEL & 1.3 \\
\hline Ammonium Hydroxide $(27 \mathrm{wt} \%)^{(5)}$ & STEL, CEIL & 5 & STEL, CEIL & 5 \\
\hline Hydrofluoric Acid (51 wt\%) & CEIL & 0.80 & CEIL & 0.80 \\
\hline Ammonium Hydroxide $(11 \mathrm{w} \%)^{(5)}$ & STEL, CEIL & 15 & STEL, CEIL & 7 \\
\hline Epichlorohydrin & STEL & 2.5 & 8-hr TWA & 31 \\
\hline Hydrogen Peroxide $(30 \mathrm{wt} \%)$ & STEL & 1.3 & 8-hr TWA & 15 \\
\hline Pyridine & 8-hr TWA & 24 & None $^{(3)}$ & None $^{(3)}$ \\
\hline n-Hexane & 8-hr TWA & 251 & None $^{(3)}$ & None $^{(3)}$ \\
\hline Frequent Use & 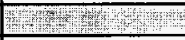 & 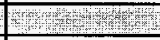 & 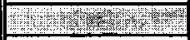 & 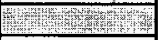 \\
\hline Nitric Acid $(70$ wt\%) & 8-hr TWA & 1.0 & None $^{(3)}$ & None $^{(3)}$ \\
\hline Insta Gel (1,2,4-trimethylbenzene) & None $^{(3)}$ & None $^{(3)}$ & None $^{(3)}$ & None $^{(3)}$ \\
\hline Ethyl Alcohol & None ${ }^{(3)}$ & None ${ }^{(3)}$ & None ${ }^{(3)}$ & None $^{(3)}$ \\
\hline
\end{tabular}

(1) Room ventillation rate of $5.83 \mathrm{~m}^{3} / \mathrm{min}$ ( 2.3 air changes / hour).

(2) Room ventillation rate of $17.5 \mathrm{~m}^{3} / \mathrm{min}$ (7 air changes / hour)

(3) No limits exceeded

(4) Hydrochtoric acid results highly dependent on concentration. See Section 9.4.3.2

(5) Ammonium Hydroxide as Ammonia. 
HNF-SD-SUP-LB-001, Rev. 0

This page intentionally left blank. 
HNF-SD-SUP-LB-001, Rev. 0

\subsection{MODEL VALIDATION}

Because of a lack of comparative data, 1ittle 222-S Laboratory-specific model validation is possible. This section provides information that qualitatively validates the evaporation and subsequent constant generation, good mixing model used for general chemical transfers (Section 9.4). These models are validated based upon previous monitoring results (Section 7 ). This section also provides a validation of the screening model based on vapor pressure, molecular weight, and exposure level (Section 6.2).

\subsection{EXPOSURE MODEL VALIDATION}

The best previous monitoring for comparison and validation of the evaporation and subsequent constant generation, good mixing model was performed February 4, 1992 for methylene chloride airborne monitoring results in room 4P (Table 7-1). The activity involved rinsing glassware. This was the only methylene chloride operation that clearly included some work on the benchtop outside of a hood. The measured concentration of methylene chloride was $60 \mathrm{ppm}\left(208.8 \mathrm{mg} / \mathrm{m}^{3}\right)$ and the 8 -hour TWA was $6.5 \mathrm{ppm}\left(22.6 \mathrm{mg} / \mathrm{m}^{3}\right)$. Based on this information, the period monitored was approximately 52 minutes.

The maximum concentration at 52 minutes is approximately $300 \mathrm{mg} / \mathrm{m}^{3}$. The average concentration for a 52 -minute exposure, based on averaging values, is approximately $270 \mathrm{mg} / \mathrm{m}^{3}$, which is greater than $208.8 \mathrm{mg} / \mathrm{m}^{3}$, but within $25 \%$. The 8-hour TWA for a 52-minute initial exposure is $34 \mathrm{mg} / \mathrm{m}^{3}$, which is greater than $22.6 \mathrm{mg} / \mathrm{m}^{3}$, but within $35 \%$. Agreement within $35 \%$ is very good. Most modeling for this type of activity is considered reliable if within a factor of $10(1,000 \%)$. Based on this, it can be assumed that the model can conservatively, but realistically, estimate exposures.

This validation is considered qualitative. It cannot be considered quantitative because only one sample was available for comparison, the activities were not identical, and the values measured did not necessarily include the time that the individual was in the laboratory but the chemical was in the hood.

\subsection{SCREENING MODEL VALIDATION}

In Section 6.2, a screening model was used to determine target chemicals of concern based upon molecular weight, vapor pressure, and airborne limits. This screening method was demonstrated in Section 9.4 to be effective at indicating chemical concentrations that may exceed airborne limits. The chemicals of concern were generally presented in terms of usage categories, not sequentially by airborne screening factor. Table 10-1 provides two data points for the chemicals of concern: (1) airborne screening factors arranged in decreasing numerical value (Section 6.2) and (2) the time the chemical must be left out of the hood to reach the 8-hour TWA airborne limit

(Section 9.4.3). These times are presented graphically for each chemical in Appendix F. 
Table 10-1. Comparison of Screening Factors and Exposures.

\begin{tabular}{|l|r|c|}
\hline \multicolumn{1}{|c|}{ Chemical of Concern } & $\begin{array}{c}\text { Airborne Screening } \\
\text { Factor }\end{array}$ & $\begin{array}{c}\text { Time to Reach } \\
\text { Airborne Limit }\end{array}$ \\
\hline \hline Bromine & 39,265 & $1 \mathrm{~min}$ \\
\hline Benzene & 1,802 & $24 \mathrm{~min}$ \\
\hline Hydrochloric Acid & 1,095 & No 8 - hr TWA \\
\hline $\begin{array}{l}\text { Amonia Hydroxide } \\
\text { (14.5m) }\end{array}$ & 983 & $37 \mathrm{~min}$ \\
\hline Hydrofluoric Acid & 257 & $115 \mathrm{~min}$ \\
\hline Ammonium Hydroxide (6m) & 182 & $195 \mathrm{~min}$ \\
\hline Methylene Chloride & 171 & $260 \mathrm{~min}$ \\
\hline Epichlorohydrin & 158 & $290 \mathrm{~min}$ \\
\hline Hydrogen Peroxide 30\% & 121 & $295 \mathrm{~min}$ \\
\hline Pyridine & 84 & $>8 \mathrm{hrs}$ \\
\hline n-Hexane & 61 & $>8 \mathrm{hrs}$ \\
\hline
\end{tabular}

1 Based on molecular weight, vapor pressure, and exposure limit, as described in Section 6.2.

2 Time the chemical must be left out of the hood for the totsl exposure, averaged over 8 hours.

to reach the exposure limit under typical ventilation conditions (See Table 9-3).

As can be seen in Table 10-1, the two values are inversely proportional; the higher the airborne factor, the shorter the time to reach the airborne limit. This data indicates that using this model will effectively indicate chemicals of concern.

Based on these values, an approximate airborne screening value equal to or greater than 170 could be used to indicate chemicals of concern under the conditions modeled. This value is based upon a 4-hour time with the chemical outside of the hood causing exceedance of the 8-hour TWA limit and the following equation derived from the data in Table 10-1.

Equation 10-1:

$\log$ (Airborne Factor) $=-0.9638[\log$ time $(\mathrm{min})]+4.53$

Note: Equation correlation equals 0.90

After this initial screening, the individual chemicais can be evaluated to determine if sufficient volume is used to allow exceedance of 1 imits (Section 9.4.3.2). 


\subsection{AIRBORNE CHEMICAL MONITORING RECOMMENDED}

This section identifies the recommended monitoring for the 222-S Laboratory complex based on the airborne chemical concentration estimates in Section 9.

\subsection{ROOM 4L FLAMMABLE STORAGE CABINET}

Airborne chemical concentration estimates indicate that maximum concentrations in room $4 \mathrm{~L}$ resulting from opening one or more storage cabinets could be high, but average concentrations would not likely exceed airborne limits (Section 9.1). As a precaution, Cabinet 2 should be periodically monitored during opening as long as chemicals and odors are present. It is recommended that an annual monitoring frequency be used. Active monitoring should initially be performed to assist in identifying chemicals and establish airborne concentrations. Passive badges may be evaluated for use after initial monitoring.

\subsection{ROON 2B DECONTAMINATION STATION}

Exposure estimates could not be adequately made for this exposure. Because of the activities performed and the presence of lead, decontamination activities in room $2 B$ should be periodically monitored. An annual monitoring frequency is recommended unless decontamination methods change. Both lead and nitric acid should be initially evaluated. If nitric acid levels are demonstrated to be low, then only one compound should be evaluated each year; most likely lead.

\subsection{CHEMICAL USAGE OUTSIDE OF HOODS}

As stated in Section 10, the general chemical transfer models are effective at predicting exposures outside of hoods. Based on predicted exposures, the following chemicals should be monitored any time they are used outside of hoods until use-specific patterns can be developed or concentrations lower than those typical in the 222-SA Laboratory are used.

$\begin{array}{ll}- & \text { Bromine } \\ \text { - } & \text { Henzene } \\ \text { - } & \text { Ammonium Hydroxide }(>11 \mathrm{wt} \%) \\ \text { Hydrochloric Acid (> } 30 \text { wt } \%)\end{array}$

New chemicals, chemicals with similar properties but no established exposure limits, and diluted forms of the above chemicals should be evaluated by industrial hygiene personnel based on molecular weight, vapor pressure (in $\mathrm{mmHg}$ ), and either known or estimated exposure $1 \mathrm{imits}$ ( $\mathrm{in} \mathrm{mg} / \mathrm{m}^{3}$ ) using the exposure factor formula (Section 10.2) to determine if similar exposure levels are likely if used outside of hoods. An exposure factor of 170 could be used to identify chemicals of concern (Section 10.2). 
In addition, if organic chemicals are used outside of hoods it is recommended that monitoring be periodically performed as a demonstration of acceptable exposure levels. An annual monitoring frequency is recommended. This is particularly true of methylene chloride in light of current regulatory efforts (60 FR 54462 and 60 FR 62360) to reduce exposure leve1s. Passive badges may be used for this monitoring.

\subsection{MERCURY DISTILLATION}

According to laboratory personnel, the mercury distillation unit, previously in room $4 \mathrm{E}$, has not been used for some time. There is no monitoring available for this operation. In addition there was no clear local ventilation path. Because of the extremely low airborne limit of mercury and the fact that materials will be heated, any future mercury distillation with this equipment should include monitoring. Engineering controls should first be instituted to remove any residual mercury vapor. Surface contamination surveys should aiso be performed in room $4 \mathrm{E}$ to determine if there have been previous spills.

\subsection{MAINTENANCE CHEMICALS}

The 222-S Laboratory complex contains several maintenance chemicals. These chemicals include paints and solvents that may result in significant exposure depending on usage. It is recommended that airborne monitoring of these activities be performed as controlled through the Job Control System. Monitoring during subcontractor activities is al so recommended. 
HNF-SD-SUP-LB-001, Rev. 0

\subsection{MONITORING NOT RECOMMENDED}

This section describes the monitoring that is not considered necessary based on this evaluation.

\subsection{SOLIDS MONITORING IN THE 222-SA STANDARDS LABORATORY}

This evaluation has demonstrated that exposure to solids in the 222-S Standards Laboratory are likely very low and should not be further evaluated.

\subsection{MOST CHEMICALS}

With the exception of the chemicals listed in Section 11.3, airborne concentrations from most chemicals should be low and should not be further evaluated unless there is some mechanism outside of hoods that would create elevated airborne concentrations such as heating materials, vigorous stirring, or transfer of large quantities of materia1. The 222-s Laboratory complex's commitment to perform most operations inside of hoods minimizes the potential for increased chemical airborne concentrations. 
HNF-SD-SUP-LB-001, Rev. 0

This page intentionally left blank. 


\subsection{CONCLUSIONS AND OTHER RECOMMENDATIONS}

The 222-S Laboratory complex has an established system of engineering controls (i.e., hoods), procedures, and qual ified personnel to control exposures to potentially harmful materials, including chemicals and radionuclides. Monitoring has been performed in the past but has been by request only. Based on the information in this evaluation, there are some conditions where exposures could occur but exceedance of established limits is highly unlikely due to existing controls. The following general

recommendations are provided.

Modeling has been performed to estimate airborne concentrations. The modeling results for potential high airborne concentration chemicals and frequently used chemicals is summarized in Table 13-1.

\subsection{PERFORM PERIODIC AND TASK SPECIFIC MONITORING}

A periodic monitoring schedule should be established in accordance with Section 11. Task specific monitoring should also be performed in accordance with Section 11.5, Job Control System requirements, and industrial hygiene requirements, including asbestos and lead monitoring.

\subsection{EVALUATE HOOD USAGE}

The primary means for chemical exposure control is the hoods. Managers should be vigilant in ensuring hoods are used whenever necessary. Continued emphasis of this in training, and possible addition of this item to monthly inspections would assist in this emphasis.

\subsection{FURTHER EVALUATE AND MODIFY MERCURY DISTILLATION}

The mercury distillation unit should not be operated until surface monitoring is performed and engineering controls are implemented to remove mercury vapors.

\subsection{UTILIZE AIRBORNE SCREENING FACTOR AND VOLUME COMPARISON}

This evaluation demonstrated the effectiveness of the airborne screening factor for chemical use outside of hoods (Sections 6.2 and 10.2). Use of this factor could be incorporated into the Chemical Hygiene Plan. By identifying chemicals of concern, then determining if volumes used can cause limits to be exceeded, controls can be established for the minimum number of chemicals.

\subsection{MONITOR STORAGE CABINETS AND EITHER REMOVE CHEMICALS OR EVALUATE VENTING STORAGE CABINETS IF NEEDED}

The cabinets in room $4 \mathrm{~L}$ should be monitored for airborne chemical concentrations. If levels indicate that employee exposures are elevated and approaching limits, the changes recommended in the section should be further evaluated. 
Table 13-1. Chemicals of Concern - Summary Information.

\begin{tabular}{|c|c|c|c|c|}
\hline Chemical Name & $\begin{array}{l}\text { Limiting } \\
\text { Airborne } \\
\text { Limit }\end{array}$ & $\begin{array}{l}\text { Limiting } \\
\text { Concentration } \\
\left(\mathrm{mg} / \mathrm{m}^{3}\right)\end{array}$ & $\begin{array}{l}\text { Time to Reach } \\
\text { Limit (min) }\end{array}$ & $\begin{array}{l}\text { Volume to Reach } \\
\text { Limit (mL) }\end{array}$ \\
\hline $\begin{array}{l}\text { High Potential Exposure (Frequent Use) } \\
\text { Hydrochloric Acid (38\%) } \\
\text { Hydrochloric Acid (30\%) } \\
\text { Methylene Chloride }\end{array}$ & $\begin{array}{l}\text { CEIL } \\
\text { NONE } \\
\text { 8-hr TWA }\end{array}$ & $\begin{array}{c}7 \\
\text { NA } \\
174 \\
\end{array}$ & $\begin{array}{c}1 \\
\text { NA } \\
260 \\
\end{array}$ & $\begin{array}{l}2.2 \\
\text { NA } \\
755\end{array}$ \\
\hline $\begin{array}{l}\text { High Potential Exposure } \\
\text { Bromine } \\
\text { Benzene } \\
\text { Ammonium Hydroxide }(14.5) \\
\text { Ammonium Hydroxide }(6 \mathrm{~m}) \\
\text { Hydrofluoric Acid } \\
\text { Epichlorohydrin } \\
\text { Hydrogen Peroxide } 30 \% \\
\text { Pyridine }\end{array}$ & $\begin{array}{l}\text { STEL } \\
\text { STEL } \\
\text { STEL } \\
\text { STEL } \\
\text { CEIL } \\
\text { 8-hr TWA } \\
\text { 8-hr TWA } \\
\text { NONE }^{(5)}\end{array}$ & $\begin{array}{c}1.3 \\
16 \\
35 \\
35 \\
2.5 \\
7.6 \\
1.4 \\
\text { NONE }\end{array}$ & $\begin{array}{c}1 \\
2 \\
1 \\
16 \\
2 \\
290 \\
295 \\
\text { NONE }\end{array}$ & $\begin{array}{c}1.2 \\
1.3 \\
5 \\
7 \\
0.8 \\
31 \\
15 \\
\text { NONE }\end{array}$ \\
\hline $\begin{array}{l}\text { Frequent Use } \\
\text { Nitric Acid } \\
\text { Insta Gel (1,2,4-trimethyl benzene) } \\
\text { Ethyl Alcohol } \\
\text { n-Hexane }\end{array}$ & $\begin{array}{l}\text { NONE } \\
\text { NONE } \\
\text { NONE } \\
\text { NONE }\end{array}$ & $\begin{array}{l}\text { NONE } \\
\text { NONE } \\
\text { NONE } \\
\text { NONE }\end{array}$ & $\begin{array}{l}\text { NONE } \\
\text { NONE } \\
\text { NONE } \\
\text { NONE }\end{array}$ & $\begin{array}{l}\text { NONE } \\
\text { NONE } \\
\text { NONE } \\
\text { NONE }\end{array}$ \\
\hline
\end{tabular}

"Most restrictive of OSHA or ACGIH limits

(2) Assume typical ventilation (air changes/hr)

(sI TWA - time weighted average

"IISTEL - short-term exposure limit

"5N NONE - no airborne limits exceeded 
Conditions in which employees are advised to leave a work area for venting (e.g., when Cabinet 2 is opened in room $4 \mathrm{~L}$ ) should be avoided. If exposure is an issue, removal of the chemicals is the preferred solution. If this cannot be done, cabinet venting should be evaluated in accordance with OSHA recommended practices (Section 5.1.1) and NFPA 30 (NFPA 1991).

The NFPA 30, Flammable and Combustible Liquids Code, generally recommends not venting flammable material cabinets. If venting is needed, the construction material should be similar (e.g., schedule 40 pipe) and venting must be done to an outside location. If air movement is necessary, either a Class 1 Division 1 motor and fan shall be used inside the system or an external motor and an Air Movers Contract Association (AMCA) Class A nonsparking fan is needed. 
HNF-SD-SUP-LB-001, Rev. 0

This page intentionally left blank. 
HNF-SD-SUP-LB-001, Rev. 0

\subsection{REFERENCES}

AIHA and ACGIH, 1996, Professional Development Course 402, A Tool Box of Mathematical Models for Occupational Exposure Assessment, American Industrial Hygiene Association and the American Conference of Governmental Industrial Hygienists, Course Manua 7, 1996, American Industrial Hygiene Conference and Exposition, Washington, D.C.

ACGIH, 1996, Threshold Limit Values for Chemical Substances and Physical Agents, 1996, American Conference of Governmental Industrial Hygienists, Cincinnati, ohio.

ACGIH, 1988, Industrial Ventilation, A Manual of Recommended Practice, 20th Edition, American Conference of Governmental Industrial Hygienists, Cincinnati, Ohio.

AMCA, 1986, Standards Handbook, Publication 99-86, Air Movement and Control Association, Inc., Arlington Heights, Illinois.

Caplan, K.J. and Knutson, G.W., 1978, Laboratory Fume Hoods: Influence of Room Air Supply, ASHRAE Transaction, Vo1. 84, Part 2, 1978

Cowherd, C. Jr, Grelinger, M. A., and Wong, K. F., 1989, Dust Inhalation Exposures from the Handling of Small Volumes of Powders, American Industrial Hygiene Association Journal 50(3):131-138, March, 1989.

de Nevers, N., 1995, Air Pollution Control Engineering, McGraw Hi1l, Inc., New York.

DOE, 1989, General Design Criteria, DOE Order 6430.1A, U.S. Department of Energy, Washington, D.C.

EPA, 1991, Preparation of Engineering Assessments, Volume 1 CEB Engineering Manual Draft, U.S. Environmental Protection Agency Office of Toxic Substances, Washington D.C.

Evans, R. A., 1994, Radiological Design Guide, WHC-SD-GN-DGS-30011, Rev. 0, Westinghouse Hanford Company, Richland, Washington.

MSA, 1996, Response Respirator Selector, Mine Safety, Pittsburgh, Pennsylvania.

National Research Council, 1981, Prudent Practices for Handling Hazardous Chemicals in Laboratories, National Academy Press, Washington D.C.

NFPA, 1991, Flammable and Combustible Liquids Code, 30, National Fire Protection Association, Quincy, Massachusetts.

NIOSH; 1994, NIOSH Pocket Guide to Chemical Hazards, National Institute for Occupational Safety and Health, U.S. Department of Health and Human Services, NIOSH Publications, Cincinnati, Ohio.

Sant, W., 1995, Westinghouse Hanford Company Chemical Hygiene P7an, WHC-SD-CP-HSP-001, Westinghouse Hanford Company, Richland, Washington. 
Stoetzel, G. A. and Cicotte, G. R., 1992, Evaluation of Air Flow Patterns in Selected Areas of the 222-5 Laboratory Complex, Pacific Northwest Laboratories, Richland, Washington.

Stoetzel, G. A. and Hickey, E. E., 1990, Evaluation of Air Sampling and Monitoring Locations in the 2225 Facility Draft, Pacific Northwest Laboratories, Richland, Washington.

Weaver, L. L., 1996, 222-S Laboratory Interim Safety Basis, WHC-SD-CP-ISB-002, Rev. 1, Westinghouse Hanford Company, Richland, Washington. 
HNF-SD-SUP-LB-001, Rev. 0

APPENDIX A

LABORATORY CHEMICAL INVENTORY INFORMATION

A-1 
HNF-SD-SUP-LB-001, Rev. 0

This page intentionally left blank. 


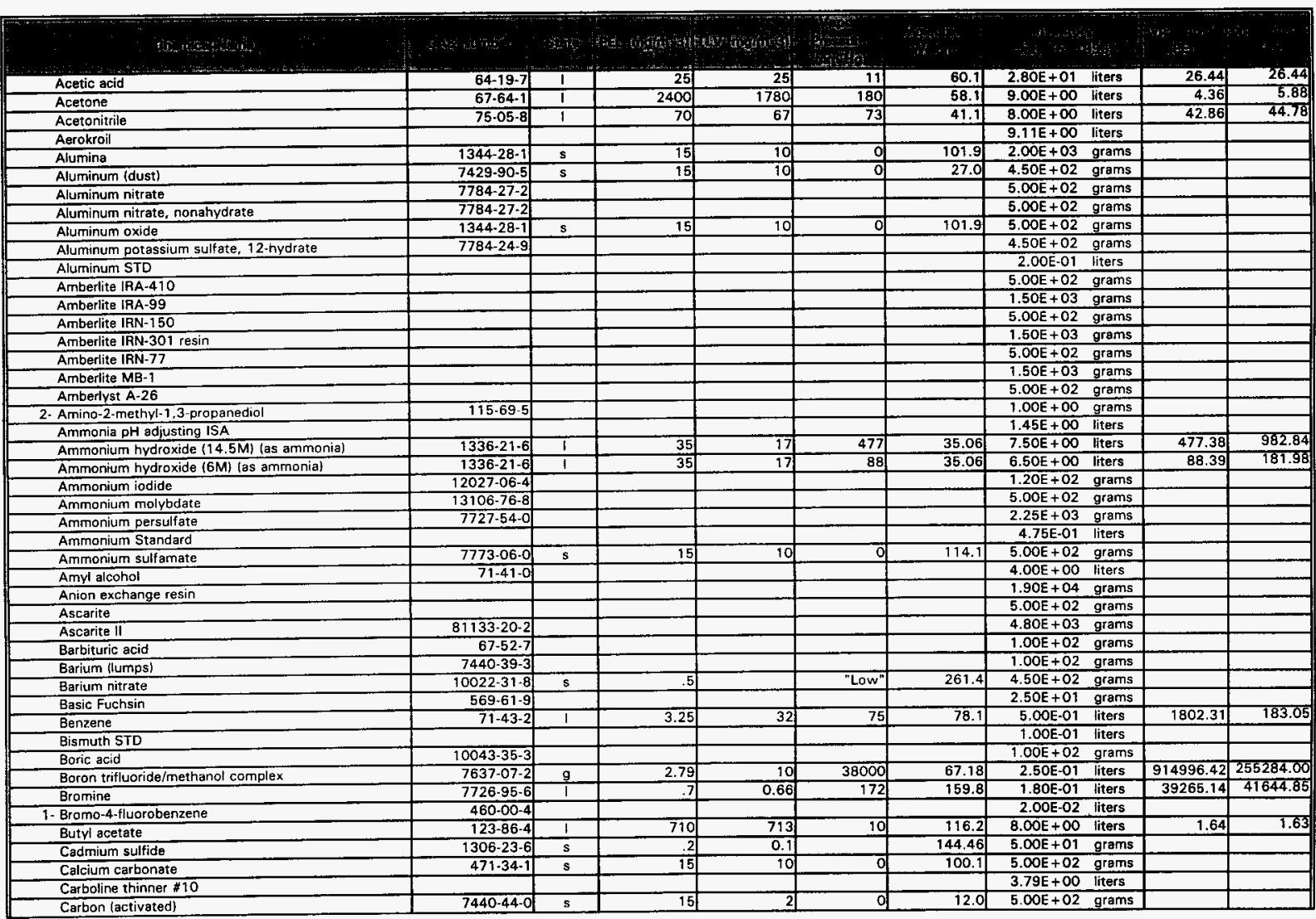


Carbon anode solution

Carbon cathode solution

Carbosorb

Carquest FA (ATT)

Cation exchange resin

Ceric oxide

Cesium chloride

Cesium nitrate

Chloramine-T hydrate

Chlorobenzene

Chromium nitrate, nonahydrate

Citranox

Copper [II] sulfide

Decane

Dibutyl-N,N-diethylcarabamoyl phosponate

Diglycolic acid

Dodecane

Drierite

Duolite C-3

Duolite ES-286

EDTA, disodium

Electrode solution Orion $\mathrm{pH}$

Electrowash

Epichlorohydrin

Ethyl acetate

Ethylene glycol

Ferric nitrate

\begin{tabular}{l|l}
\hline & $10421-48-4$ \\
\hline
\end{tabular}

\begin{tabular}{l|l}
\hline & \\
\hline
\end{tabular}

Ferrous sulfide

Fission Product Stock

2- Flake graphite

Fluorobenzene

Foam-trol 205

Formaldehyde soiution

D- Glucose

L. Glutamic acid

Glycolic acid

Glyptal 1201A

Hexadecane

Hexane

L- Histidine

Hydrobromic acid

Hydrochloric acid

\begin{tabular}{|c|c|}
\hline $7783-85-9$ & \\
\hline $1317-37-9$ & \\
\hline & \\
\hline $462-06 \cdot 6$ & 1 \\
\hline $50-00-0$ & 1 \\
\hline $50-99-7$ & \\
\hline $56-86-0$ & 5 \\
\hline 56-81-6 & $\mathrm{T}$ \\
\hline $79-14-1$ & $\mathbf{s}$ \\
\hline $544-76-3$ & \\
\hline $110-54-3$ & I \\
\hline $71-00-1$ & $\mathrm{~s}$ \\
\hline $10035-10-6$ & I \\
\hline $7647-01-0$ & 1 \\
\hline
\end{tabular}

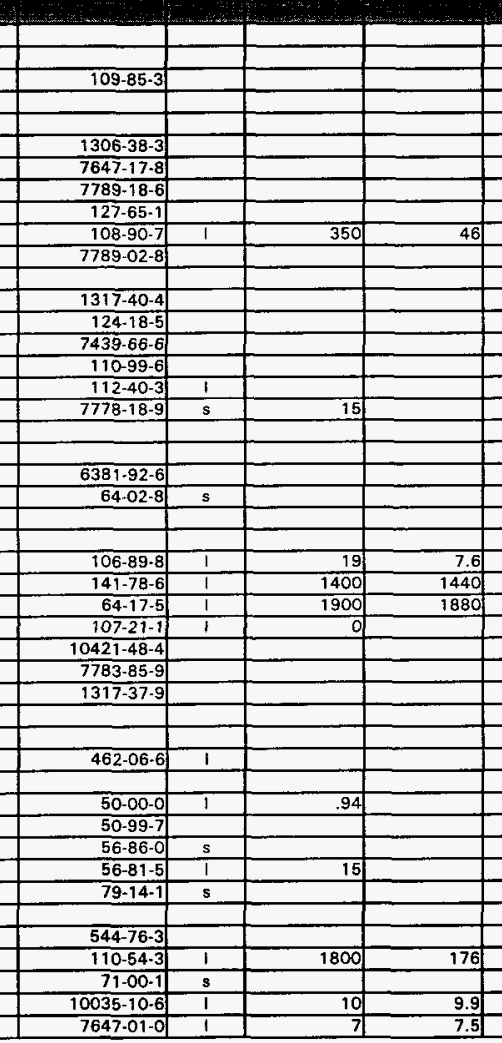

7.5

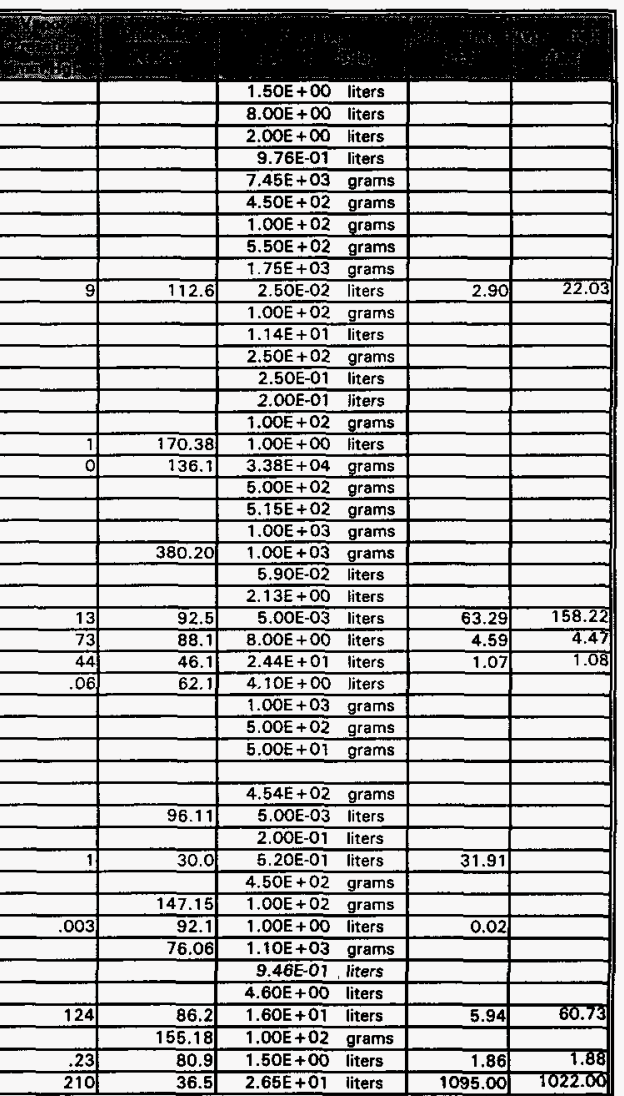




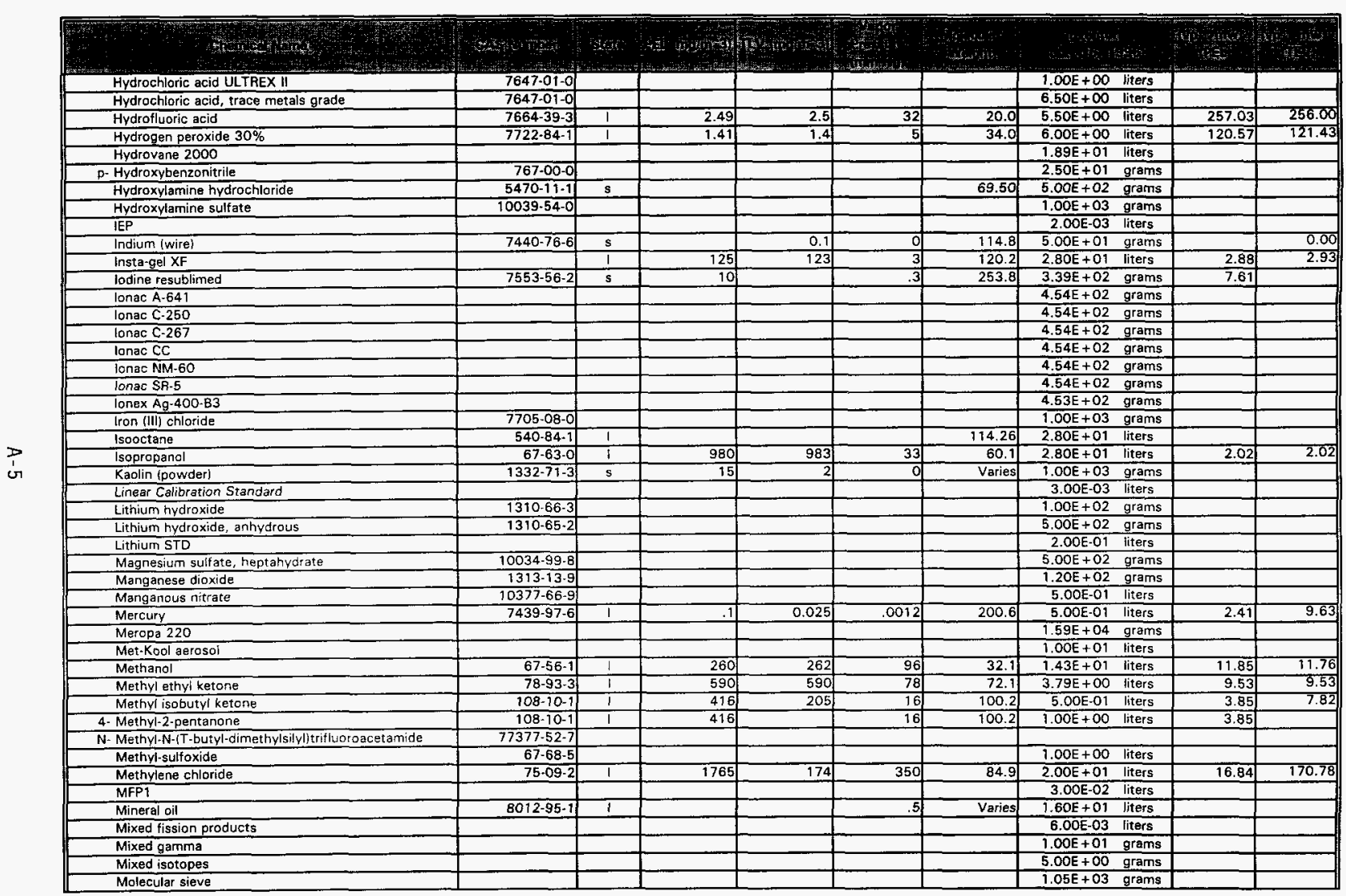




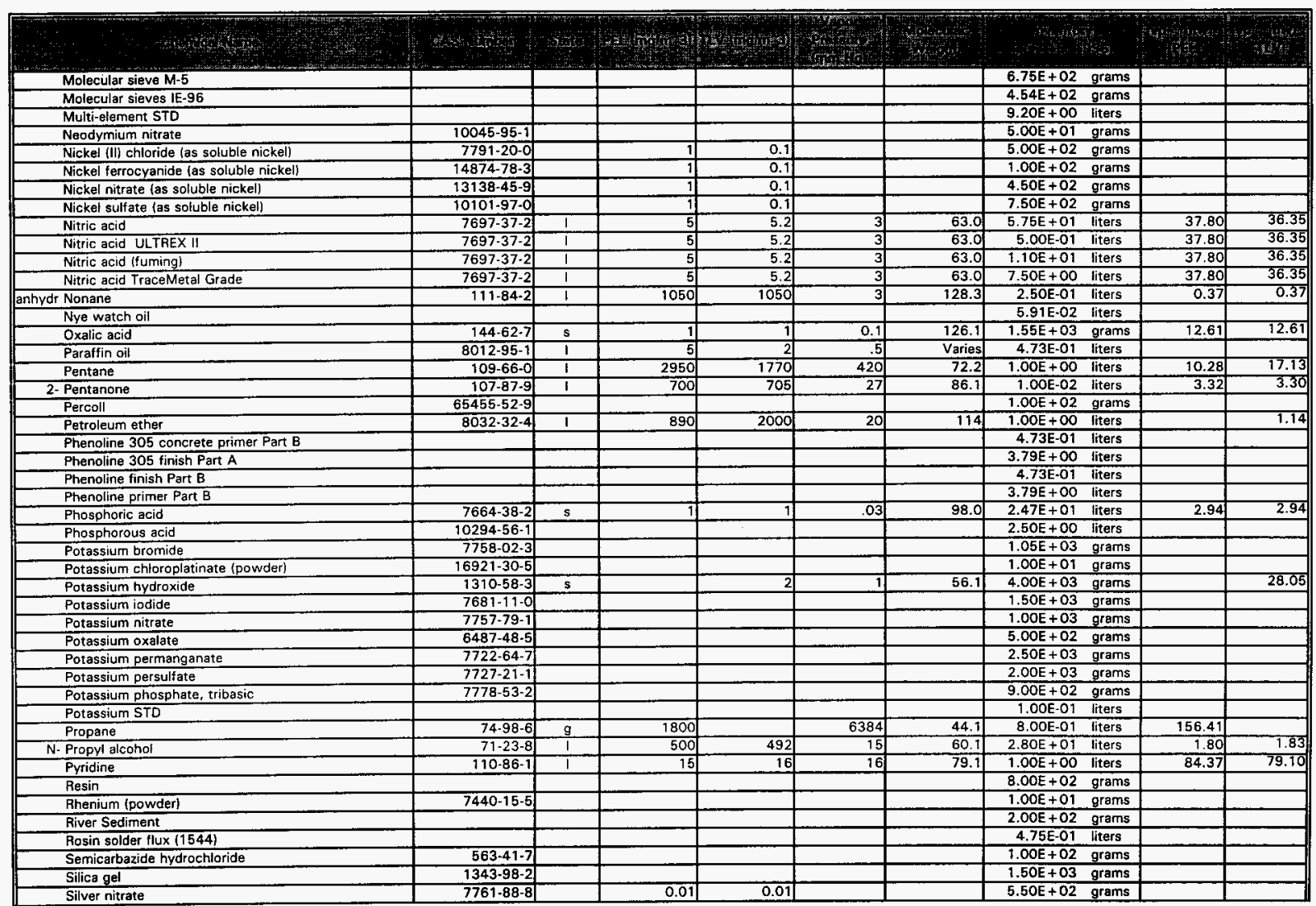




\begin{tabular}{|c|c|c|c|c|c|c|c|c|c|c|}
\hline \multirow[t]{2}{*}{ 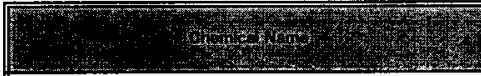 } & 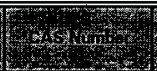 & (n) & $(4,4+013$ & 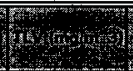 & 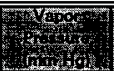 & 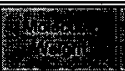 & 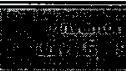 & 8 & (1) & and \\
\hline & & & 0.01 & 10.01 & & & $1.00 E+00$ & liters & & \\
\hline Sodium acetate & $6131-90-4$ & & & & & & $1.50 E+03$ & grams & & \\
\hline Sodium bisulfite & $7631-90-5$ & s & & 5 & & 104.1 & $1.45 E+03$ & grams & & \\
\hline Sodium borohydride & $16940-66-2$ & & & & & & $6.00 E+02$ & grams & & \\
\hline Sodium carbonate & $497 \cdot 19 \cdot 8$ & & & & & & $5.00 E+02$ & grams & & \\
\hline Sodium carbonate, anhydrous & $497-19-8$ & & & & & & $1.00 \mathrm{E}+03$ & grams & & \\
\hline Sodium carbonate, monohydrate & & & & & & & $5.00 E+02$ & grams & & \\
\hline Sodium chloride & $7647 \cdot 14-5$ & & & & & & $2.50 E+03$ & grams & & \\
\hline Sodium citrate & 68-04-2 & & & & & & $4.50 E+02$ & grams & & \\
\hline Sodium D-gluconate & $527-07-1$ & $s$ & & & & & $5.00 E+02$ & grams & & \\
\hline Sodium hydrosulfite & $7775 \cdot 14-4$ & & & & & & $5.00 E+01$ & grams & & \\
\hline Sodium hydroxide & $1310-73-2$ & $s$ & 2 & 2 & & 40.0 & $8.00 E+03$ & grams & & \\
\hline Sodium iodide & $7681-82.5$ & & & & & & $5.00 E+02$ & grams & & \\
\hline Sodium metabisulfite & $7681-57-4$ & s & & 5 & & 190.1 & $3.40 E+03$ & grams & & \\
\hline Sodium nitrate & $7631-99-4$ & & & & & & $5.00 E+03$ & grams & & \\
\hline Sodium nitrite & $7632-00.0$ & & & & & & $1.00 E+03$ & grams & & \\
\hline Sodium oxalate & $62.76 \cdot 0$ & & & & & & $4.50 E+02$ & grams & & \\
\hline Sodium periodate & $7790-28-5$ & & & & & & $5.00 E+00$ & grams & & \\
\hline Sodium persulfate & $7775-27-1$ & & & & & & $5.00 E+02$ & grams & & \\
\hline Sodium phosphate, anhydrous & $7601-54-9$ & & & & & & $4.50 E+02$ & grams & & \\
\hline Sodium phosphate, tribasic dodecahydrate & $10101-89-0$ & & & & & & $5.00 \mathrm{E}+02$ & grams & & \\
\hline Sodium salicylate & $54-21.7$ & & & & & & $5.00 E+02$ & grams & & \\
\hline Sodium sulfate anhydrous & $7757-82-6$ & & & & & & $8.00 E+03$ & grams & & \\
\hline Sodium sulfide, 9-hydrate & $1313-84-4$ & & & & & & $5.00 E+02$ & grams & & \\
\hline Spray-on vinyl strippable protective & & & & & & & $4.73 \mathrm{E}-01$ & liters & & \\
\hline Spraytec anti-static spray & & & & & & & $1.77 \mathrm{E}+00$ & liters & & \\
\hline Sr Spec Analytical Resin & & & & & & & $4.00 E+01$ & grams & & \\
\hline Stannous chloride & $7772-99-8$ & & & & & & $4.50 E+02$ & grams & & \\
\hline Steamate 2004 & $100-37-8$ & 1 & 48 & & 1 & 117.2 & $4.16 \mathrm{E}+02$ & liters & 2.44 & \\
\hline Stopcock grease & & & & & & & $2.10 \mathrm{E}-01$ & liters & & \\
\hline Strontium chloride & $10476 \cdot 85 \cdot 4$ & & & & & & $1.25 \mathrm{E}+02$ & grams & & \\
\hline Strontium nitrate anhydrous & $10042-76 \cdot 9$ & & & & & & $1.00 \mathrm{E}+03$ & grams & & \\
\hline Sulfuric acid & $7664-93-9$ & $\mathrm{~T}$ & 1 & 1 & .001 & 98.1 & $2.60 E+01$ & liters & 0.10 & 0.10 \\
\hline Sulfuric acid ULTREX II & $7664-93.9$ & 1 & 1 & 1 & .001 & 98.1 & $1.50 \bar{E}+00$ & liters & 0.10 & 0.10 \\
\hline Sulfurous acid & $7782-99 \cdot 2$ & $\mathrm{~T}$ & & & & 82.08 & $1.00 E+00$ & fiters & & \\
\hline Tetradecane & $629-59-4$ & $!$ & & & 1 & 198.44 & $5.00 E-01$ & liters & & \\
\hline Tetraethylene givcol dimethyl ether & $143-24-8$ & & & & & & $5.00 E+01$ & grams & & \\
\hline Tetraethylenepentamine pentahydrochloride & $496 \div-41-5$ & & & & & & $1.00 E+01$ & grams & & \\
\hline Tetrahydrafuran & 109-99-9 & $T$ & 590 & 590 & 132 & 72.1 & $2.50 \mathrm{E}-02$ & liters & 16.13 & $16 . \overline{13}$ \\
\hline TEVA-Spec SPS & & & & & & & $1.00 \mathrm{E}+02$ & grams & & \\
\hline Thorium & $7440 \cdot 29 \cdot 1$ & & & & & & & & & \\
\hline Thorium nitrate & $13823-29-5$ & & & & & & & & & \\
\hline Tin (granular) & $7440-31-5$ & & & & & & $5.00 E+02$ & grams & & \\
\hline Tin (IV) sulfide & 1315-01-1 & & & & & & $5.00 E+00$ & grams & & \\
\hline Titanium trichloride solution & $7705-07-9$ & & & & & & $1.18 \mathrm{E}-01$ & liters & & \\
\hline Toluene & 108-88-3 & 1 & 766 & 188 & 21 & 92.1 & $1.30 \mathrm{E}+01$ & liters & 2.52 & 10.29 \\
\hline
\end{tabular}




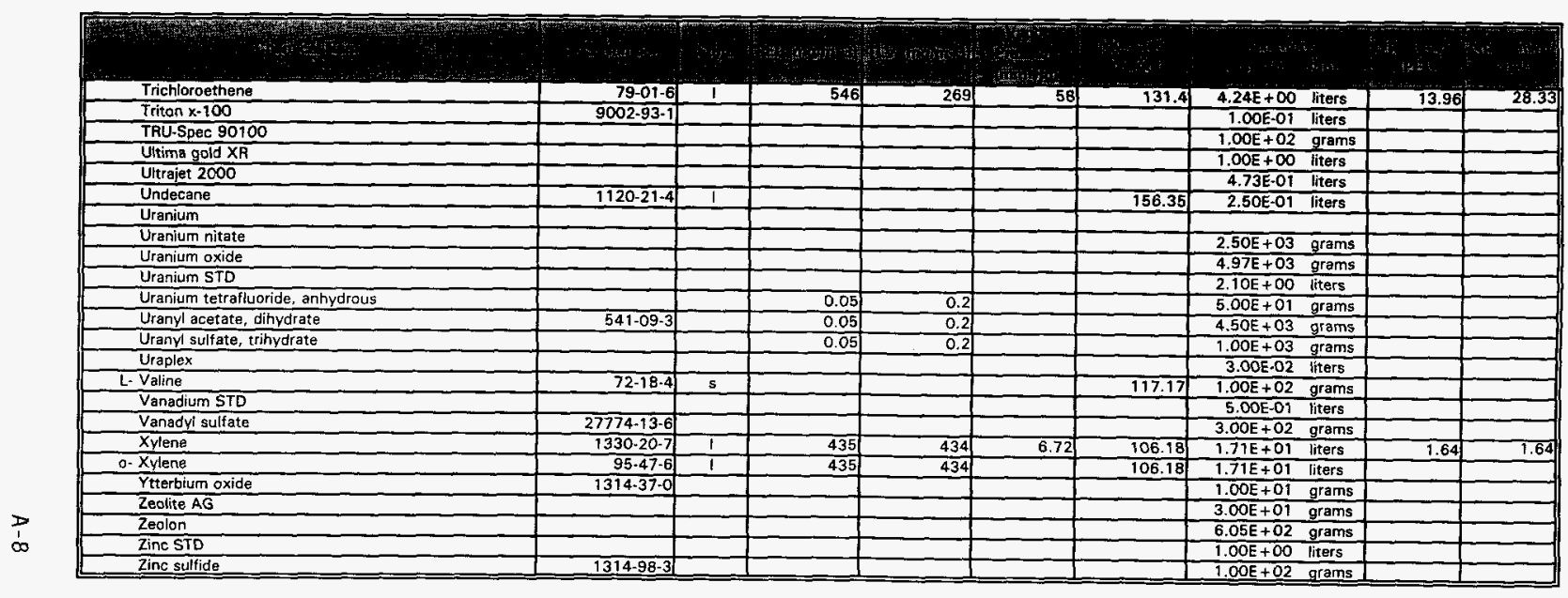


HNF-SD-SUP-LB-001, Rev. 0

APPENDIX B

STORAGE CABINET MODEL INFORMATION

B-1 
HNF-SD-SUP-LB-001, Rev. 0

This page intentionally left blank. 


\section{PROBLEM STATEMENT}

When opening doors, strong organic smell is present for approximately 15 minutes. When the doors are opened, what is the concentration in Room $4 L$ under various scenarios?

\section{DATA}

There are no open containers

Initial Room Concentration $=0 \mathrm{mg} / \mathrm{m}^{3}$

Room volume and air flow based on previous storage room, Room 4E - Room 4L very similar.

$$
\begin{aligned}
\text { Room volume } & =(\text { length })(\text { width })(\text { height })=26 \mathrm{ft} \times 20 \mathrm{ft} \times 10 \mathrm{ft} \\
& =5,200 \mathrm{ft}^{3}\left(\frac{1 \mathrm{~m}^{3}}{35.31 \mathrm{ft}^{3}}\right) \\
& =147 \mathrm{~m}^{3}
\end{aligned}
$$

$$
\begin{aligned}
& \text { Cabinet Volume } \\
& 65^{\prime \prime} \times 31 \frac{1^{\prime \prime}}{4} \times 31 \frac{1^{\prime \prime}}{4}=6.35 \times 10^{4} \operatorname{inches}^{3}\left(\frac{f t^{3}}{1728 i n c h e s^{3}}\right)\left(\frac{m^{3}}{35.31 f t^{3}}\right) \\
& =1.04 m^{3} \\
& \cong 1 m^{3}
\end{aligned}
$$


STORAGE CABINET MODEL INFORMATION

$$
\begin{aligned}
& \text { Air Changes per hour }=\frac{Q}{\text { roomvolume }} \\
&=\frac{37.1 \frac{\mathrm{m}^{3}}{\mathrm{~min}}}{147 \mathrm{~m}^{3}}\left(\frac{60 \mathrm{~min}}{\mathrm{hr}}\right) \\
&=15 \mathrm{hr}^{-1} \\
& Q^{\prime}=\text { Effective ventilation }=\frac{Q}{K} \\
& K=3 \text { Based on ACGIH Ventilation Manual } 37.1 \frac{\mathrm{m}^{3}}{\mathrm{~min}} \\
& Q^{\prime}=\frac{12.4 \mathrm{~m}^{3}}{\mathrm{~min}^{2}}
\end{aligned}
$$

\section{PROBLEM STATEMENT A}

What is the generation rate if assuming xylene?

\section{ASSUMPTIONS}

Cabinet air 1/10th saturated with xylene. 1/10th chosen because there are no open/broken containers. Any leakage is through diffusion, a very slow process.

Cabinet air changed out in 15 minutes

\section{DATA}

Contaminate is P-xylene

Molecular weight: $106.2 \mathrm{~g} / \mathrm{g}$-mole

Vapor pressure: $9 \mathrm{~mm}$

Liquid density: $0.86 \mathrm{~g} / \mathrm{mL}$

OSHA PEL: $100 \mathrm{ppm}(435 \mathrm{mg} / \mathrm{m} 3$ )

Source: NIOSH Pocket Guide 


\section{STORAGE CABINET MODEL INFORMATION}

Filling rate:

$$
\begin{aligned}
& r_{15}=\text { tank fill rate }=\frac{1}{\text { air changeout time }}=\frac{1}{15 \mathrm{~min}} \\
& =0.067 \mathrm{~min}^{-1} \\
& G_{x}=\text { mass rate of } x y l \text { ene released } \\
& =\frac{r_{15} \vee \text { Pavap } f\left(M W_{x}\right)}{R T} \\
& r_{15}=\text { filling rate }=0.067 \mathrm{~min}^{-1} \\
& v=\text { volume of cabinet }=0.75 \mathrm{~m}^{3} \\
& \text { Pavap }=\text { vapor pressure of contaminate }=(9 \mathrm{~mm})\left(\frac{1 \mathrm{~atm}}{760 \mathrm{~mm}}\right)=1.18 \times 10^{-2} \mathrm{~atm} \\
& f=\text { factor accounting for nonsaturated volume }=0.1 \\
& m w_{x}=\text { molecular weight of } x y l \text { ene }=106.2 \frac{\mathrm{g}}{\mathrm{g}-\mathrm{mole}} \\
& R=8.205 \times 10^{-5} \frac{m^{3} \mathrm{~atm}}{g-\mathrm{molek}} \\
& T=\text { temp } \in{ }^{\circ} \mathrm{K} \text { (assumed room) }=298.15 \mathrm{~K} \\
& G_{x}=\frac{\left(0.067 \mathrm{~min}^{-1}\left(0.75 \mathrm{~m}^{3}\right)\left(1.18 \times 10^{-2} \mathrm{~atm}\right)(0.1)\left(106.2 \frac{\mathrm{g}}{\mathrm{g-mole}}\right)\right.}{\left(8.205 \times 10^{-5} \frac{\mathrm{m}^{3} \mathrm{~atm}}{\mathrm{g-mole} \mathrm{K}}\right)\left(298.15^{\circ} \mathrm{K}\right)} \\
& =0.258 \frac{g}{\min }
\end{aligned}
$$

Volume of Xylene released

$$
\begin{aligned}
& =\left(0.258 \frac{G}{\min }\right)(15 \mathrm{~min})\left(\frac{1}{0.86 \mathrm{~g} / \mathrm{m} 7}\right) \\
& =4.5 \mathrm{~m} 7
\end{aligned}
$$

\section{PROBLEM STATEMENT B}

What is the maximum room concentration?

\section{ASSUMPTIONS}

Cabinet air change out in 15 minutes Instantaneous room mixing xylene 
DATA

$$
\begin{aligned}
& C_{x \max }=\frac{G_{x}}{Q^{\prime}}+\left(C_{x o}-\frac{G x}{Q^{\prime}}\right) e^{-\frac{Q^{\prime}\left(t-t_{0}\right)}{v}} \\
& G_{x}=\text { generation rate of } x y 7 \text { ene }=0.258 \frac{g}{\min } \\
& Q^{\prime}=\text { effective volumetric air flowrate }=12.4 \frac{\mathrm{m}^{3}}{\mathrm{~min}} \\
& C_{x O}=\text { initial room concentration }=0 \\
& t=t \text { ime of concern }=15 \mathrm{~min} \\
& t_{0}=\text { initial time }=0 \\
& v=\text { room volume }=147 \mathrm{~m}^{3} \\
& C_{x, \max }=\frac{0.258 \frac{\mathrm{g}}{\mathrm{min}}}{12.4 \frac{\mathrm{m}^{3}}{\mathrm{~min}}}+\left(0-\frac{0.258 \frac{\mathrm{g}}{\mathrm{min}}}{12.4 \frac{\mathrm{m}^{3}}{\mathrm{~min}}}\right) e^{-\frac{12.4 \frac{\mathrm{m}^{3}}{\min }(15 \mathrm{~min})}{147 \mathrm{~m}^{3}}} \\
& =0.015 \frac{g}{m^{3}} \\
& =15 \frac{m g}{m^{3}}(3 p p m)
\end{aligned}
$$

\section{PROBLEM STATEMENT $\mathrm{C}$}

What is the maximum room concentration if the contaminate is methylene chloride?

\section{ASSUMPTIONS}

All others as stated above

DATA

Contaminate is methylene chloride Molecular weight: 84.9

Vapor pressure: $350 \mathrm{~mm}$ 


\section{STORAGE CABINET MODEL INFORMATION}

Liquid density: 1.33

OSHA PEL: $500 \mathrm{ppm}\left(1739 \mathrm{mg} / \mathrm{m}^{3}\right)$

ACGIH TLV: $50 \mathrm{ppm}\left(174 \mathrm{mg} / \mathrm{m}^{3}\right)$

Source: NIOSH Pocket guide

ACGIH TLV handbook

From previous calculation:

$$
\begin{aligned}
G_{m c}=G_{x}\left(\frac{\left(P_{m c}\right)\left(m w_{m c}\right)}{\left(P_{x}\right)\left(m w_{x}\right)}\right) \\
G_{m c}=\text { Generation rate methylene chloride } \\
G_{x}=\text { Generation rate } x y \text { lene } \\
P=\text { Vapour pressure } \\
m w=\text { Molecular weight } \\
=0.258 \frac{g}{\mathrm{~min}}\left(\frac{350 \mathrm{~mm}}{9 \mathrm{~mm}}\right)\left(\frac{84.9 \frac{\mathrm{g}}{\mathrm{g}-\mathrm{mole}}}{106.2 \frac{\mathrm{g}}{\mathrm{g-mole}}}\right) \\
G_{m c}=8.02 \frac{\mathrm{g}}{\mathrm{min}}
\end{aligned}
$$

Volume Released $=\left(8.02 \frac{\mathrm{g}}{\mathrm{min}}\right)(15 \mathrm{~min})\left(\frac{1}{1.33 \mathrm{~g} / \mathrm{ml})}\right.$

$$
=90.4 \mathrm{ml}
$$

All units previously described

$$
C_{m c} \max =\frac{G_{m c}}{Q^{\prime}}+\left(C_{m c o}-\frac{G_{m c}}{Q^{\prime}}\right) e^{-\frac{o^{\prime}\left(t-t_{o}\right)}{v}}
$$


STORAGE CABINET MODEL INFORMATION

$$
\begin{aligned}
& C_{m c} \max =0.464 \frac{\mathrm{g}}{\mathrm{m}^{3}} \\
= & 464 \frac{\mathrm{mg}}{\mathrm{m}^{3}} \quad(135 \mathrm{ppm})
\end{aligned}
$$

\section{PROBLEM STATEMENT D}

What is the maximum concentration if methylene chloride is the contaminate and the Cabinet air change is reduced from 15 minutes to 5 minutes?

\section{ASSUMPTIONS}

As above except new Cabinet air change out time

DATA

$$
\begin{aligned}
& \text { New filling rate }=r_{5}=\frac{1}{5 \min }=0.2 \mathrm{~min}^{-1} \\
& G_{m c_{\text {new }}}=G_{m c_{0}} \frac{r_{5}}{r_{15}} \\
& =8.02 \frac{g}{\min }\left(\frac{0.2 \mathrm{~min}^{-1}}{0.067 \mathrm{~min}^{-1}}\right) \\
& G_{m c_{n o w}}=23.9 \frac{\mathrm{g}}{\mathrm{min}} \\
& C_{m c_{\text {now }}^{\text {now }}}=\left(\frac{G_{m c_{\text {now }}}}{Q^{\prime}}\right)+\left(C_{m c_{0}}-\frac{G_{m c_{\text {new }}}}{Q^{\prime}}\right) e^{-\frac{\left.12.4 \frac{m^{3}}{\min } 15 \mathrm{~min}\right)}{147 m^{3}}}
\end{aligned}
$$

A11 units previously described $t=5$ minutes

$$
C_{m c^{\text {manow }}}=663 \frac{\mathrm{mg}}{\mathrm{m}^{3}}(194 \mathrm{ppm})
$$




\section{STORAGE CABINET MODEL INFORMATION}

\section{PROBLEM STATEMENT E}

How long will it take for the air concentration to be reduced to $1.0 \mathrm{mg} / \mathrm{m}^{3}$ with a 5 minute Cabinet air change out?

\section{ASSUMPTIONS}

Methylene chloride is contaminate

Cabinet air change out in 5 minutes

Maximum air concentration is $663 \mathrm{mg} / \mathrm{m}^{3}$

DATA

Total time = time to maximum concentration + time from maximum to target concentration

Time to maximum concentration $=5$ minutes as calculated above

Time from maximum to target concentration = purge time

$$
\begin{aligned}
C_{2} & =C_{1} e^{-\frac{Q^{\prime}\left(t-t_{0}\right)}{v}} \\
C_{2} & =\text { Target concentration }=1.0 \frac{\mathrm{mg}}{\mathrm{m}^{3}} \\
C_{1} & =\text { Initial concentration }=663 \frac{\mathrm{mg}}{\mathrm{m}^{3}} \\
t-t_{0} & =\text { Time reach target concentration }
\end{aligned}
$$

other units as previously described

Solving for $t-t_{0}$

$$
\begin{aligned}
t-t_{0} & =-\frac{v}{Q^{1}} \ln \frac{C_{2}}{C_{1}} \\
& =-\frac{147 \mathrm{~m}^{3}}{12.4 \frac{\mathrm{m}^{3}}{\mathrm{~min}}} \ln \frac{1.0}{663} \\
& =77 \mathrm{~min}
\end{aligned}
$$

Time from maximum to target concentration $=77$ minutes

Total time $=5$ minutes +77 minutes $=82$ minutes 


\section{PROBLEM STATEMENT F}

How long will it take for the air concentration to be reduced to $1.0 \mathrm{mg} / \mathrm{m}^{3}$ with a 15 minute Cabinet air change out?

\section{ASSUMPTIONS}

Methylene chloride is the contaminant

Cabinet air change out in 15 minutes

Maximum air concentration of $464 \mathrm{mg} / \mathrm{m}^{3}$

\section{DATA}

As previously described

$$
\text { Purge time }=73 \text { minutes }
$$

$$
\Rightarrow \text { Purge rate consistent } 7 y \approx 75 \text { min }
$$

\section{$\therefore$ Total time more a factor of cabinet air change out time}

Total time $=15 \mathrm{~min}+73 \mathrm{~min}$

$$
=88 \mathrm{~min}
$$


HNF-SD-SUP-LB-001, Rev. 0

APPENDIX C

222-SA STANDARDS LABORATORY SOLIDS WEIGHING MODEL INFORMATION

C -1 
HNF-SD-SUP-LB-001, Rev. 0

This page intentionally left blank.

c- 2 
HNF-SD-SUP-LB-001, Rev. 0 222-SA STANDARDS LABORATORY SOLIDS WEIGHING MODEL INFORMATION

\section{PROBLEM STATEMENT}

What is the potential exposure to airborne solids in the 222-SA Standards Laboratory?

\section{ASSUMPTIONS}

Exposure to solids in a laboratory-type environment has been evaluated and pier reviewed (Cowherd et a1. 1989). The information from that report wi 11 be used as a basis for 222-SA Standards Laboratory exposures.

Parameters from Cowherd et a1. (1989) can be used as identified below.

DATA

Per laboratory personnel:

- Al1 solids activities outside of hoods are for weighing

- $\quad>95 \%$ of weighing is $\leq 10$ grams

- On a very infrequent basis (- 1 to 2 times per year), chemicals up to $-1 \mathrm{~kg}$ are poured

- Most chemicals poured have large crystalline structures 
HNF-SD-SUP-LB-001, Rev. 0

222-SA STANDARDS LABORATORY SOLIDS WEIGHING MODEL INFORMATION

Table C-1. Conditions in Cowherd et al. (1989) and comparisons to 222-SA Standards Laboratory.

\begin{tabular}{|c|c|c|}
\hline PARANETER & COWHERD ET AL. 1989 & $\begin{array}{l}\text { 222-SA STANDARDS } \\
\text { LABORATORY }\end{array}$ \\
\hline Materials & $\begin{array}{l}\text { Talc, sodium chloride, } \\
\text { Portland cement, direct } \\
\text { Yellow } 4 \text { dye (chosen } \\
\text { for wide size range and } \\
\text { ability to cause } \\
\text { airborne contamination) }\end{array}$ & $\begin{array}{l}\text { Wide variety of material, } \\
\text { primarily large } \\
\text { crystalline structure }\end{array}$ \\
\hline Weight used & $\begin{array}{l}50 \text { to } 125 \mathrm{~kg} \text { transfers } \\
\text { tested. Each transfer } \\
\text { took } 30 \text { minutes, see } \\
\text { below for further } \\
\text { details }\end{array}$ & $\begin{array}{l}\leq 10 \text { grams usually } \\
\text { infrequently up to } \approx 1 \mathrm{~kg}\end{array}$ \\
\hline $\begin{array}{l}\text { Monitoring } \\
\text { performed }\end{array}$ & $\begin{array}{l}1 \text { hour monitoring } \\
\text { periods }\end{array}$ & No monitoring data \\
\hline Transfer methods & $\begin{array}{l}\text { Poured or scooped from } \\
14,22 \text {, and } 32 \mathrm{~cm}\end{array}$ & $\begin{array}{l}\text { Assumed similar } \\
\text { (conservation assumption, } \\
\text { typical height closer to } 1 \\
\text { to } 5 \mathrm{~cm} \text { ) }\end{array}$ \\
\hline Ventilation & $\begin{array}{l}\text { Base air exchange rate } \\
4.5 \text { air changes per } \\
\text { hour }\end{array}$ & $\begin{array}{l}7 \text { air exchanges per hour } \\
\text { typical, } 5 \text { minimum }\end{array}$ \\
\hline
\end{tabular}

As a result of comparing the conditions in Cowherd et al. (1989) and 222-SA Standards Laboratory, it is assumed that the Cowherd et a1. (1989) data can be used to conservatively estimate 222-SA Standards Laboratory potential exposure as follows.

As a result, maximum estimated 1 hour air concentration is $1 \mathrm{mg} / \mathrm{m}^{3}$ with large majority of concentrations $\leq 0.01 \mathrm{mg} / \mathrm{m}^{3}$. Eight hour time weighted average would be approximately eight times lower. 
HNF-SD-SUP-LB-001, Rev, 0

222-SA STANDARDS LABORATORY SOLIDS WEIGHING MODEL INFORMATION

This page intentionally left blank. 
HNF-SD-SUP-LP-001, Rev. 0

\section{APPENDIX D}

GENERAL CHEMICAL TRANSFER MODEL INFORMATION

$\mathrm{D}-1$ 
HNF-SD-SUP-LP-001, Rey. 0

This page intentionally left blank.

D-2 
HNF-SD-SUP-LB-001, Rev. 0

\section{GENERAL CHEMICAL TRANSFER MODEL INFORMATION}

\section{OVERALL PROBLEM STATEMENT}

What is the personal exposure to methylene chloride when pouring the chemical into a beaker under various conditions using various modeling techniques?

\section{ASSUMPTIONS}

$v=$ Room volume similar to Lab $4 \mathrm{E} \cong 150 \mathrm{~m}^{3}$

Air changes per hour $=7 \mathrm{hr}^{-1}$ based on minimum air change out design

Air flow generally $10-30 \mathrm{ft} / \mathrm{min}(3.05-9.15 \mathrm{~m} / \mathrm{min})$

DATA

$$
\begin{aligned}
Q & =\text { Volumetric airflow rate } \\
& =\left(\frac{7}{\mathrm{hr}}\right)\left(\frac{\mathrm{hr}}{60 \mathrm{~min}}\right) 150 \mathrm{~m}^{2} \\
Q & =17.5 \frac{\mathrm{m}^{3}}{\mathrm{~min}} \\
Q^{\prime} & =\text { Effective ventilation }=\frac{Q}{K} \\
K & =3 \text { Based on ACGIH } \\
Q^{\prime} & =\frac{17.5 \frac{\mathrm{m}^{3}}{\mathrm{~min}^{2}}}{3}=5.83 \frac{\mathrm{m}^{3}}{\mathrm{~min}^{3}}
\end{aligned}
$$

Methylene chloride

molecular weight: $84.9 \mathrm{~g} / \mathrm{g}$-mole

vapor pressure: $350 \mathrm{~mm}$

liquid density: 1.33

OSHA PEL: $500 \mathrm{ppm}\left(1739 \mathrm{mg} / \mathrm{m}^{3}\right)$

NIOSH Pocket Guide

\section{PROBLEM STATEMENT A}

What is the vapor generation volume if assume generation volume primarily due to saturated atmosphere displacement?

\section{ASSUMPTIONS}

Liquid volume poured equals volume of saturated atmosphere displaced Two hundred milliliters of methylene chloride are poured Evaporation contribution is negligible Standard Room Temperature Ideal Gas 


\section{GENERAL CHEMICAL TRANSFER MODEL INFORMATION}

DATA

Saturation mole fraction

$$
\begin{aligned}
& y_{a}=\text { Saturation mole fraction of methylene chloride } \\
& y_{a}=\frac{P_{\text {AVap }}}{P_{\text {ath }}} \\
& y_{a}=\frac{350 \mathrm{~mm}}{760 \mathrm{~mm}} \\
& y_{a}=0.46 \frac{\text { moles methylene chloride }}{\text { total moles }}
\end{aligned}
$$

Since Ideal gas, $y_{a}=0.46 \frac{\mathrm{m}^{3} \text { methylene chloride }}{\mathrm{m}^{3} \text { total }}$

Volume of methylene chloride released $=$ volume of headspace released (Volume fraction methylene chloride)

$$
\begin{aligned}
& \text { Volume released }_{m c}=(200 \mathrm{ml})\left(\frac{\mathrm{m}^{3}}{10^{6} \mathrm{ml}}\right) \frac{0.46 \mathrm{~m}^{3} \text { methylene chloride }}{\mathrm{m}^{3} \text { total }} \\
& \text { volume released }_{m c}=9.2 \times 10^{-5} \mathrm{~m}^{3}
\end{aligned}
$$

\section{PROBLEM STATEMENT B}

What is the airborne concentration assuming Gaussian puff with three dimensional spreading and uniform dispersion?

\section{ASSUMPTIONS}

Methylene chloride released in short time ( $\approx 10$ seconds) Gaussian puff

Uniform dispersion

Turbulent dispersion coefficient $\left(D_{r}\right)=1.0 \mathrm{~m}^{2} / \mathrm{min}\left(1.67 \times 10^{-2} \mathrm{~m}^{2} / \mathrm{s}\right)$ based upon AIHA/ACGIH if guidance in "A Tool Box of mathematical models for 0ccupational Exposure Assessment" (AIHA 1996) Worker $\approx 1$ meter from source 


\section{GENERAL CHEMICAL TRANSFER MODEL INFORMATION}

DATA

The mass of methylene chloride released is:

$$
\begin{aligned}
& \text { Mass released }=\frac{(\text { Volume released })(\text { molecular weight })}{\text { molar volume }} \\
& m=\frac{\left(9.2 \times 10^{-5} \mathrm{~m}^{3}\right)\left(84.9 \frac{\mathrm{kg}}{\mathrm{kg}-m o 7 \mathrm{e}}\right)}{\left(24.4 \frac{\mathrm{m}^{3}}{\mathrm{kg-mole}}\right)} \\
& m=3.2 \times 10^{-4} \mathrm{~kg} \\
& C_{m c}=\frac{M}{8\left(\pi t D_{z} \frac{)^{3}}{2}\right.} e^{-\frac{r^{2}}{14 d, n}} \\
& c_{m c}=\text { Concentration of methylene chloride at time } f \text {, distance } r \\
& m=\text { mass }=3.2 \times 10^{-4} \mathrm{~kg} \\
& t=t \text { ime }=10 \text { seconds } \\
& D_{t}=\text { Turbulent disperion coefficient }=1.67 \times 10^{-2} \frac{\mathrm{m}^{2}}{\mathrm{~s}} \\
& r=\text { radius }=1 \mathrm{~m} \\
& C_{m c}=\frac{\left(3.2 \times 10^{-4} \mathrm{~kg}\right)}{(8)\left((\pi)\left(1.67 \times 10^{-2} \frac{m^{2}}{\mathrm{~s}}\right)(10 \mathrm{~s})\right)^{\frac{3}{2}}} e^{-\frac{10 \mathrm{~m}^{2}}{4\left(1.67 \times 10^{-2} \frac{\mathrm{m}^{2}}{\mathrm{~s}} /(10 \mathrm{~s})\right.}} \\
& =\frac{3.2 \times 10^{-4}}{3.04}(0.224) \\
& =2.36 \times 10^{-5} \frac{\mathrm{kg}}{\mathrm{m}^{3}} \\
& \left.=23.6 \frac{\mathrm{mg}}{\mathrm{m}^{3}} \text { (1 imit is } 1739 \frac{\mathrm{mg}}{\mathrm{m}^{3}}\right)
\end{aligned}
$$


HNF-SD-SUP-LB-001, Rev. 0

GENERAL CHEMICAL TRANSFER MODEL INFORMATION

\section{PROBLEM STATEMENT $C$}

What is the generation rate if evaporation is the driving release mechanism?

\section{ASSUMPTIONS}

Methylene chloride is left in a 5.5" diameter beaker

No vapor displacement

No 7 ip effect of beaker

other assumptions as previously described

DATA

$$
G_{m c}=\frac{2.79 \times 10^{-3} M^{0.835} P \cdot\left(\frac{1}{29}+\frac{1}{m}\right)^{0.25}\left(v_{z}\right)^{0.5} A}{T^{0.05} \Delta z^{0.05} p_{t}^{0.5}}
$$

where

$$
\begin{aligned}
G_{m c} & =\text { Generation rate, } \frac{l b}{h r} \\
m & =\text { molecular weight }, \frac{7 b}{7 b \text { mole }}=84.9 \\
P . & =\text { vapor pressure, inHg }=(350 \mathrm{~mm})\left(\frac{\text { inches }}{25.4 \mathrm{~mm}}\right)=13.8 \text { inches } \\
v_{z} & =\text { air velocity, } \frac{\mathrm{ft}}{\mathrm{min}}=30 \frac{\mathrm{ft}}{\mathrm{min}} \text { (moreconservative) } \\
A & =\text { area, } \mathrm{ft}^{2}=n\left(\left(\frac{5.5 \text { inches }}{2}\right)\left(\frac{\mathrm{ft}}{12 \text { inches }}\right)\right)^{2}=0.17 \mathrm{ft}^{2} \\
T & =\text { temperature, }{ }^{\circ} \mathrm{K}=298^{\circ} \mathrm{K} \\
\Delta Z & =\text { pool length along } \mathrm{flow} \text { direction, ft } \\
& =(5.5 \text { inches })\left(\frac{\mathrm{ft}}{12 \text { inches }}\right)=0.46 \mathrm{ft} \\
P_{t} & =\text { overall pressure, atm }=1 \text { atm }
\end{aligned}
$$


GENERAL CHEMICAL TRANSFER MODEL INFORMATION

$$
\begin{aligned}
& =\frac{2.79 \times 10^{-3}(84.9)^{0.835}(13.8)\left(\frac{1}{29}+\frac{1}{84.9}\right)^{0.25}(30)^{0.50 .17}}{(298)^{0.05}(0.46)^{0.5}(1)^{0.5}} \\
& =\left(0.7522 \frac{\mathrm{lb}}{\mathrm{hr}}\right)\left(\frac{454 \mathrm{~g}}{\mathrm{lb}}\right)\left(\frac{\mathrm{g}-\mathrm{mole}}{84.9 \mathrm{~g}}\right)\left(\frac{24.47}{\mathrm{~mole}}\right)\left(\frac{10^{3} \mathrm{~cm}^{2}}{7}\right) \\
& =9,82 \times 10^{4} \frac{\mathrm{cm}}{\mathrm{hr}} \\
& =\left(0.7522 \frac{\mathrm{lb}}{\mathrm{hr}}\right)\left(\frac{\mathrm{hr}}{60 \mathrm{~min}}\right)\left(\frac{454 \mathrm{~g}}{7 \mathrm{~b}}\right)\left(\frac{10^{3} \mathrm{mg}}{\mathrm{g}}\right)=5.69 \times 10^{3} \frac{\mathrm{mg}}{\mathrm{min}}
\end{aligned}
$$

\section{PROBLEM STATEMENT D}

What is the airborne contamination if evaporation is the driving force?

\section{ASSUMPTIONS}

From the time the methylene chloride is poured to the time it is in the hood is 5 minutes

Worker remains in the lab for 4 hours 
HNF-SD-SUP-LB-001, Rev, 0

GENERAL CHEMICAL TRANSFER MODEL INFORMATION

DATA

Use basic equations for build up and purge used in storage cabinet model Find the definite integral of the following curve for time $=t_{0}$ to $t_{2}$ :

$$
\begin{aligned}
& C_{2,1}=\frac{G A}{Q}\left(1-e^{\left.-\frac{Q_{i}\left(t-T_{0}\right)}{\nabla^{2}}\right)} \text { for } t<t_{1}\right. \\
& C_{2,2}=\frac{G A}{Q}\left(1-e^{-\frac{Q}{V}\left(t_{1}-t_{0}\right)}\right)\left(e^{-\frac{Q}{V}\left(t-t_{1}\right)}\right) \text { for } t \succeq t_{1} \\
& T W A=\frac{\int_{t_{0}}^{t_{2}} c_{2} d t}{t_{2}-t_{0}} \\
& \int_{t_{0}}^{t_{2}} c_{2} d t=\int_{t_{0}}^{t_{1}} c_{2,3} d t+\int_{t_{1}}^{t_{2}} c_{2,1} d t \\
& \int_{t_{0}}^{t_{1}} c_{2,1} d t=\frac{G A}{Q}\left[\left(t_{1}-t_{0}\right)+\frac{V}{Q} e^{\frac{O}{V} t_{0}}\left(e^{-\frac{O}{V} t_{1}}-e^{\frac{O}{V} t_{0}}\right)\right] \\
& \int_{t_{1}}^{t_{2}}=\left(\frac{G A}{Q}\right)\left(-\frac{V}{Q}\right)\left(1-e^{-\frac{Q}{V}\left(t_{1}-t_{0}\right)}\right) e^{\frac{Q}{V} t_{1}}\left(e^{-\frac{Q}{V} t_{2}}-e^{-\frac{Q}{V} t_{1}}\right) \\
& T W A=\left(\frac{1}{t_{2}-t_{0}}\right)\left(\frac{G A}{Q}\right)\left[\left(t_{1}-t_{0}\right)+\frac{V}{Q} e^{\frac{Q}{V} t_{0}}\left(e^{-\frac{Q}{V} t_{1}}-e^{\frac{Q}{V} t_{0}}\right)\right] \\
& -\left(\frac{1}{t_{2}-t_{0}}\right)\left(\frac{G_{A} V}{Q^{2}}\right)\left(1-e^{-\frac{Q}{\nabla}\left(t_{1}-t_{0}\right)}\right) e^{\frac{Q}{\nabla} t_{1}}\left(e^{-\frac{Q}{\nabla} t_{2}}-e^{-\frac{Q}{\nabla} t_{3}}\right)
\end{aligned}
$$

D-8 
HNF-SD-SUP-LB-001, Rev. 0

APPENDIX E

MAXIMUN AIRBORNE CONCENTRATIONS UNDER TYPICAL VENTILATION CONDITIONS

E-1 
HNF-SD-SUP-LB-001, Rev. 0

This page intentionally left blank. 
Maximum Concentration of Hydrochloric Acid in Room

Typical Ventillation (7 air changes/hr)

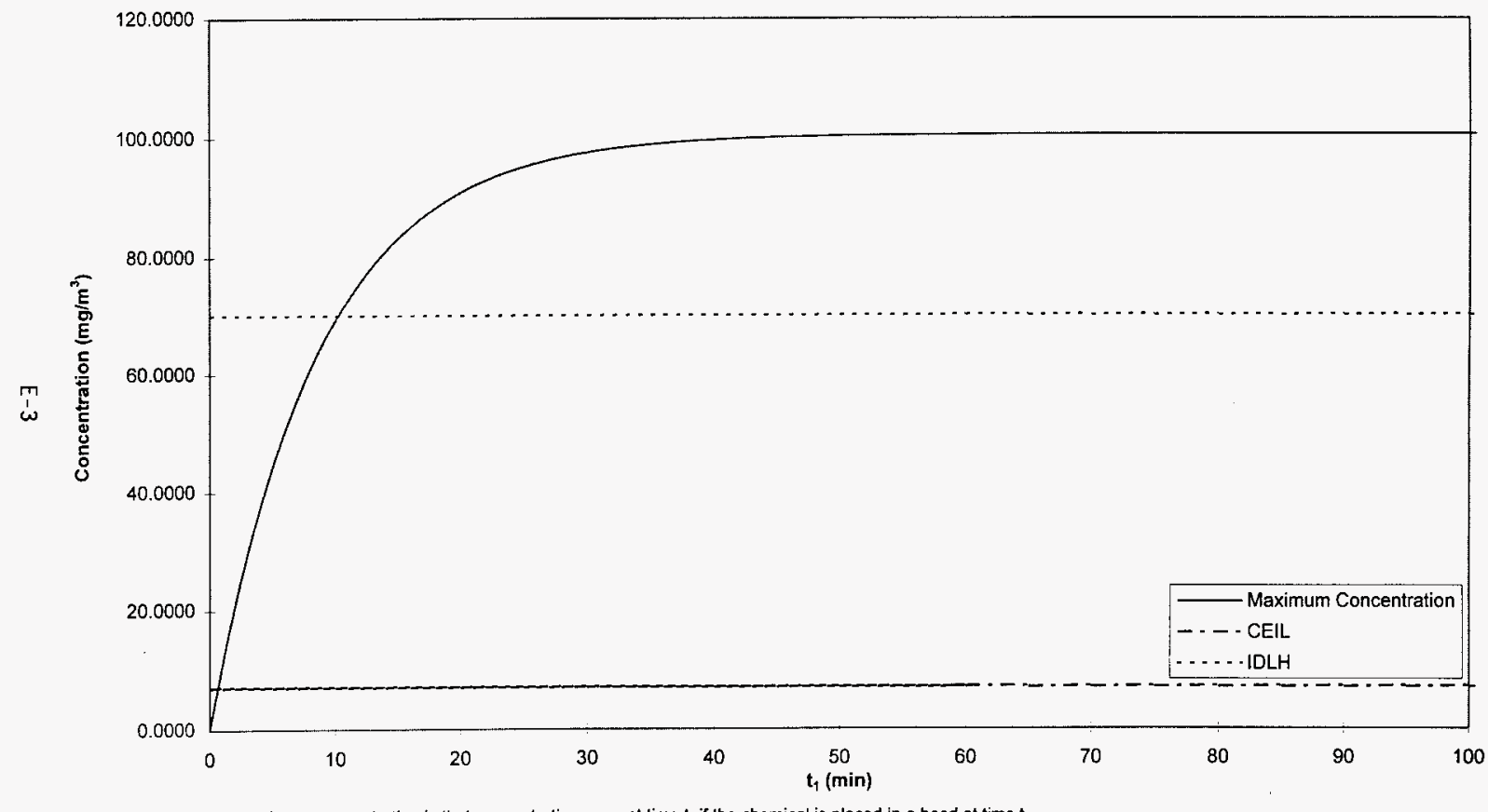

(1) Maximum concentration is that concentration seen at time $t$, if the chemical is placed in a hood at time $t$.

(2) Average concentration is cumulative average concentration if the chemical is placed in a hood at time $t$, and the person remains in the area for 4

hours.

(3) Exposure limit is the most restrictive from OSHA or ACGIH. 


\section{Maximum Concentration of Methylene Chloride in Room}

Typical Ventillation ( 7 air changes/hr)

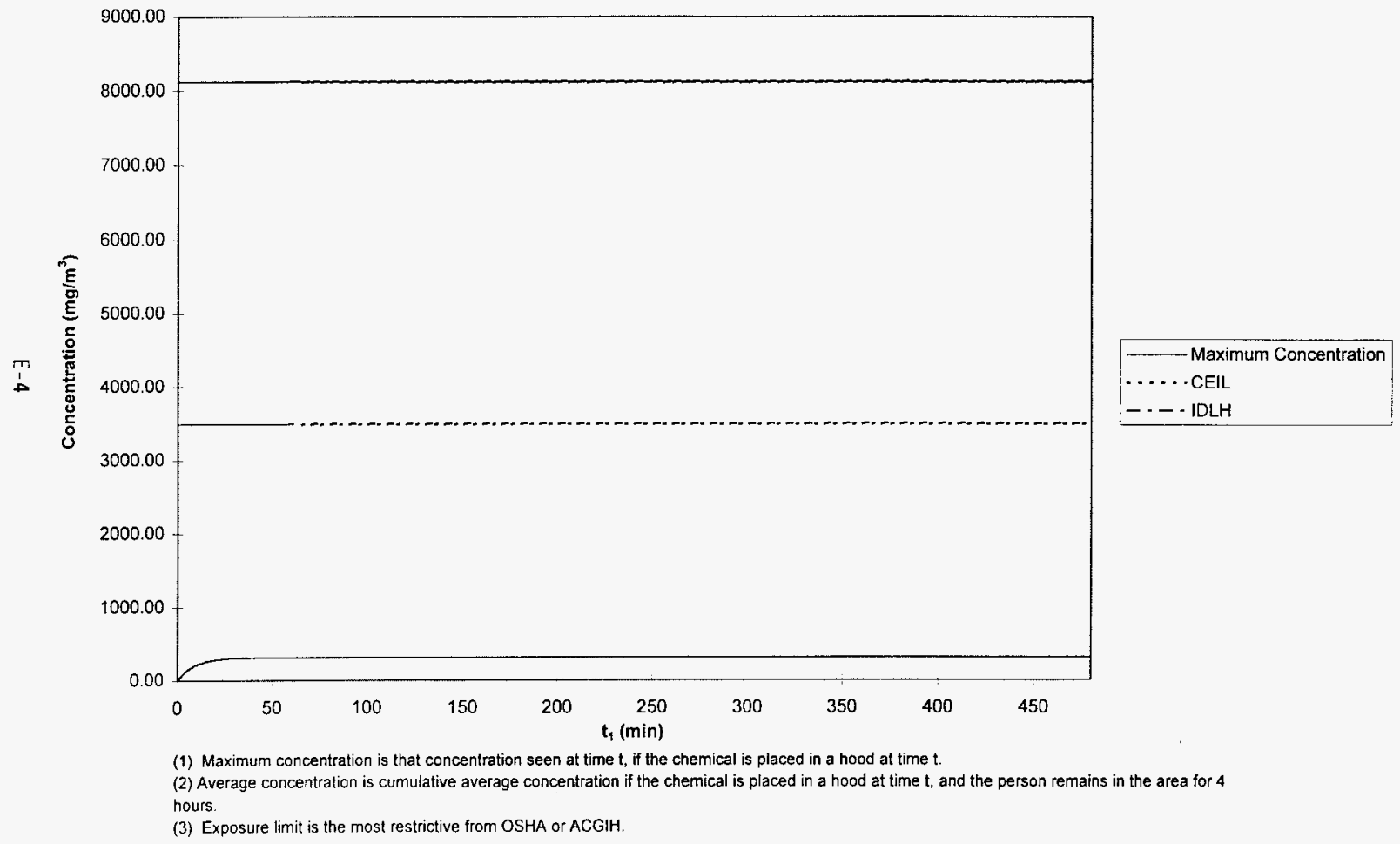




\section{Maximum Concentration of Bromine in Room}

Typical Ventillation (7 air changes/hr)

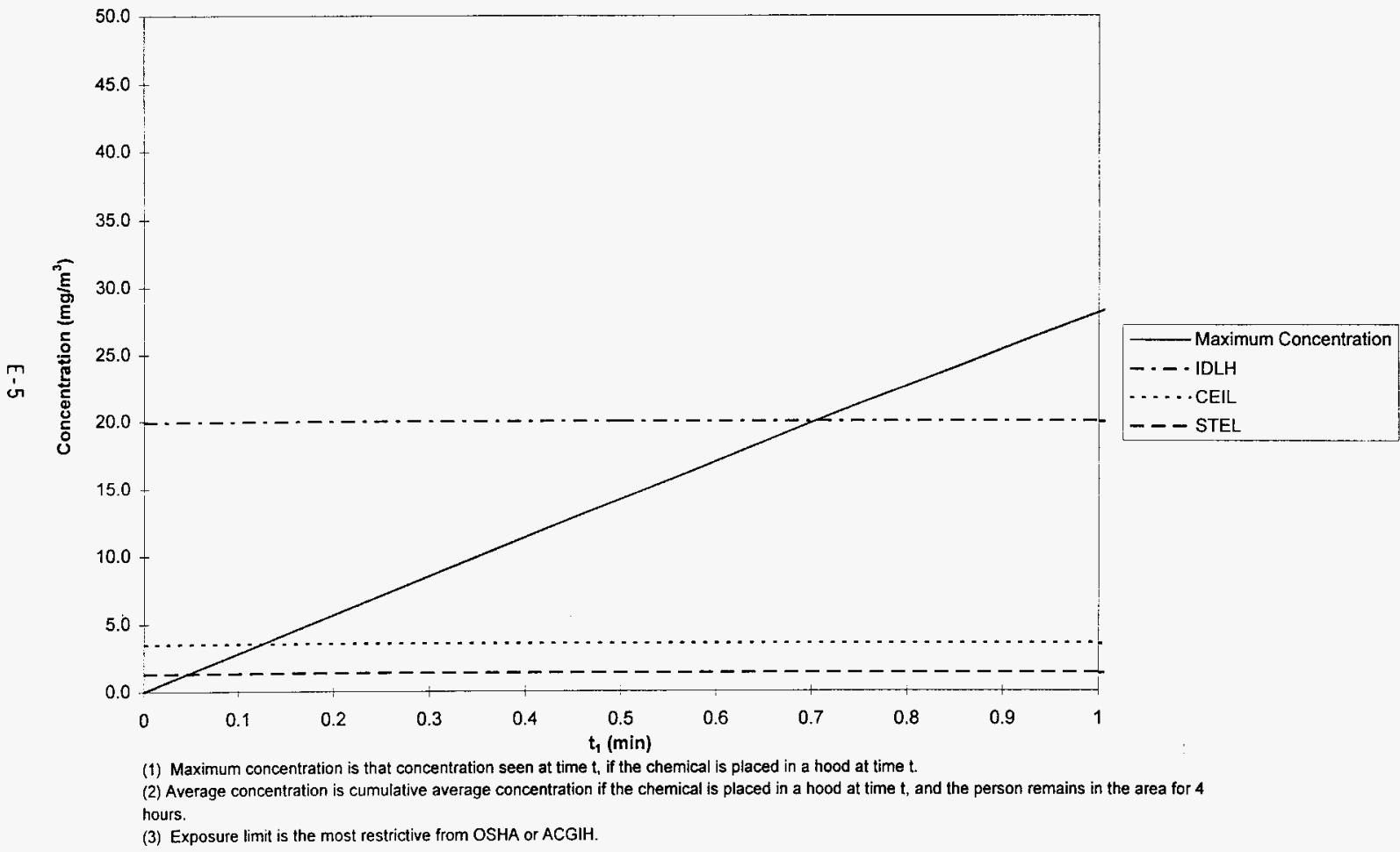




\section{Maximum Concentration of Benzene in Room \\ Typical Ventillation ( 7 air changes/hr)}

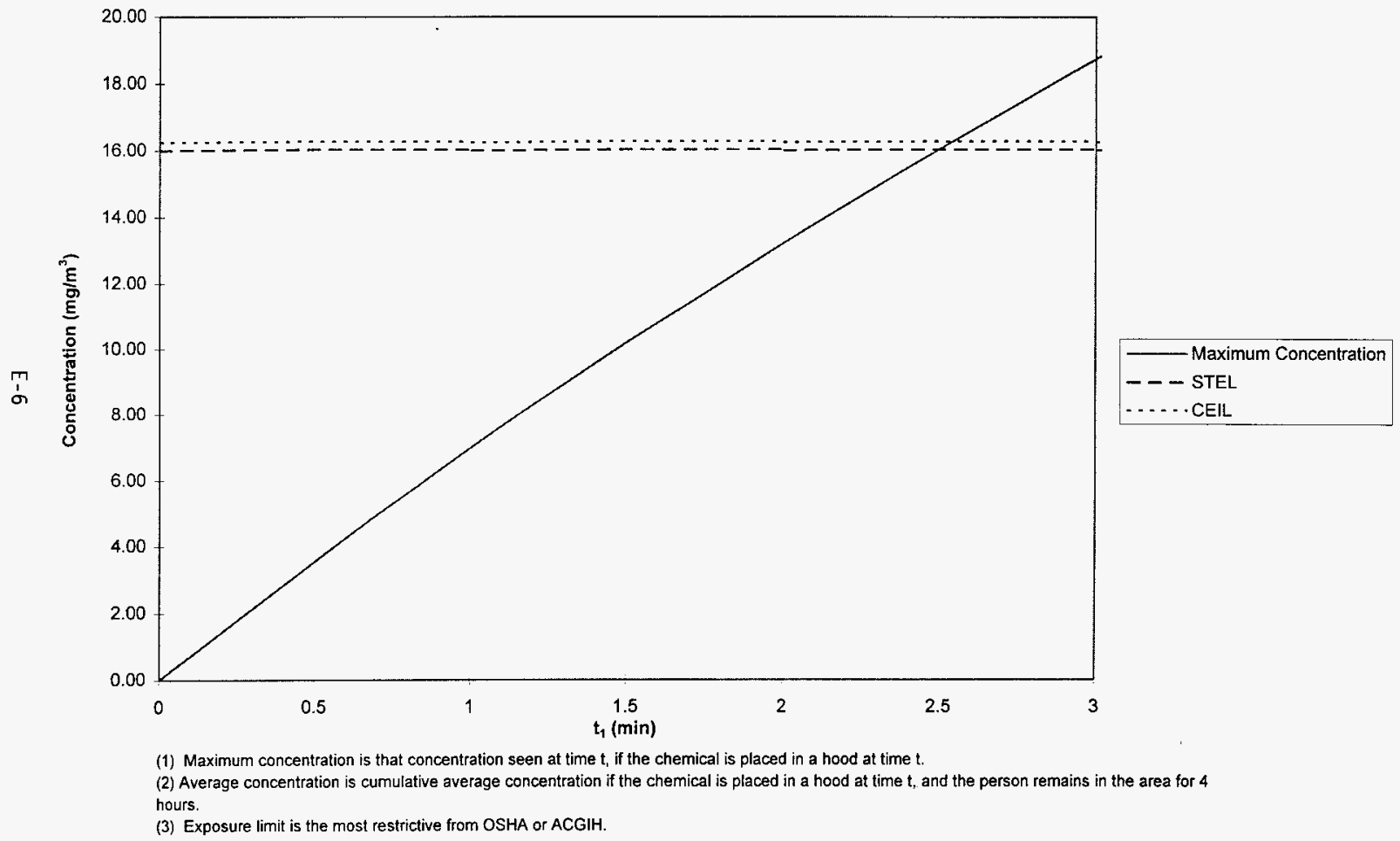


Maximum Concentration of $\mathbf{2 7}$ Wt\% Ammonium Hydroxide (as Ammonia) in Room Typical Ventillation ( 7 air changes/hr)

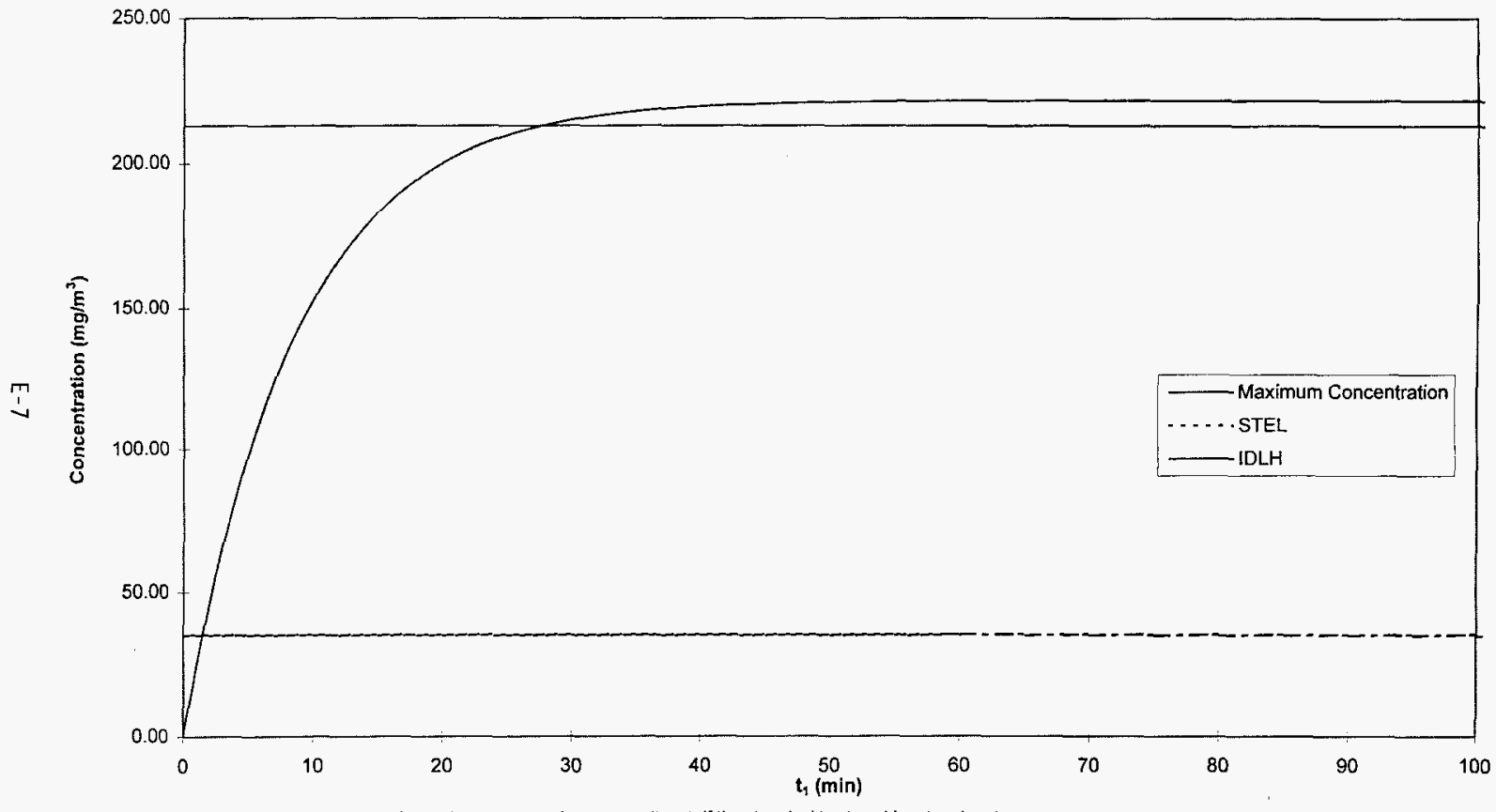

(1) Maximum concentration is that concentration seen at time $t$, if the chemical is placed in a hood at time $t$.

(2) Average concentration is cumulative average concentration if the chemical is placed in a hood at time $t$, and the person remains in the area for 4

hours.

(3) Exposure limit is the most restrictive from OSHA or ACGIH 


\section{Maximum Concentration of Hydrofluoric Acid in Room \\ Typical Ventillation ( 7 air changes/hr)}

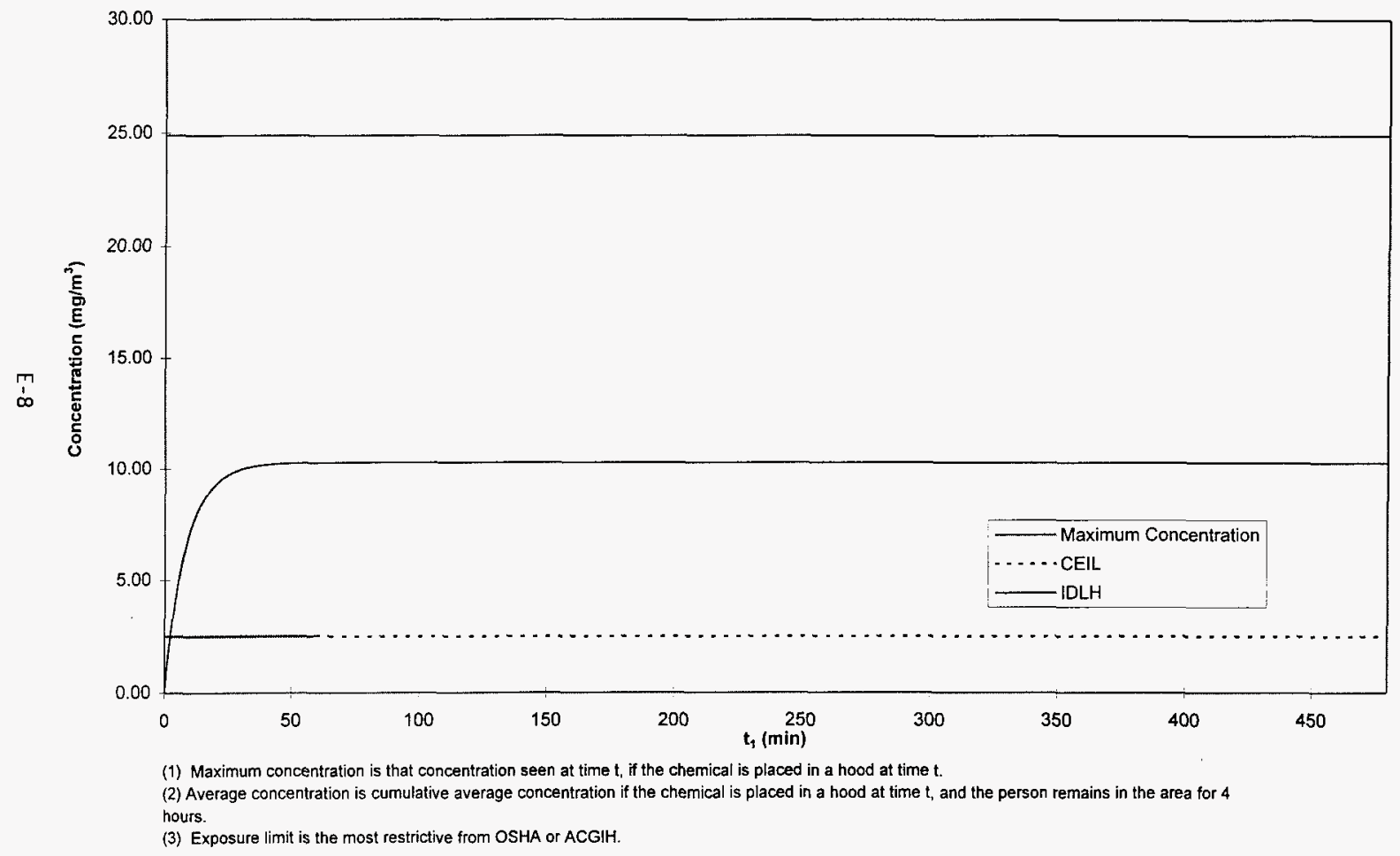


Maximum Concentration of $11 \mathrm{Wt} \%$ Ammonium Hydroxide (as Ammonia) in Room Typical Ventillation (7 air changes/hr)

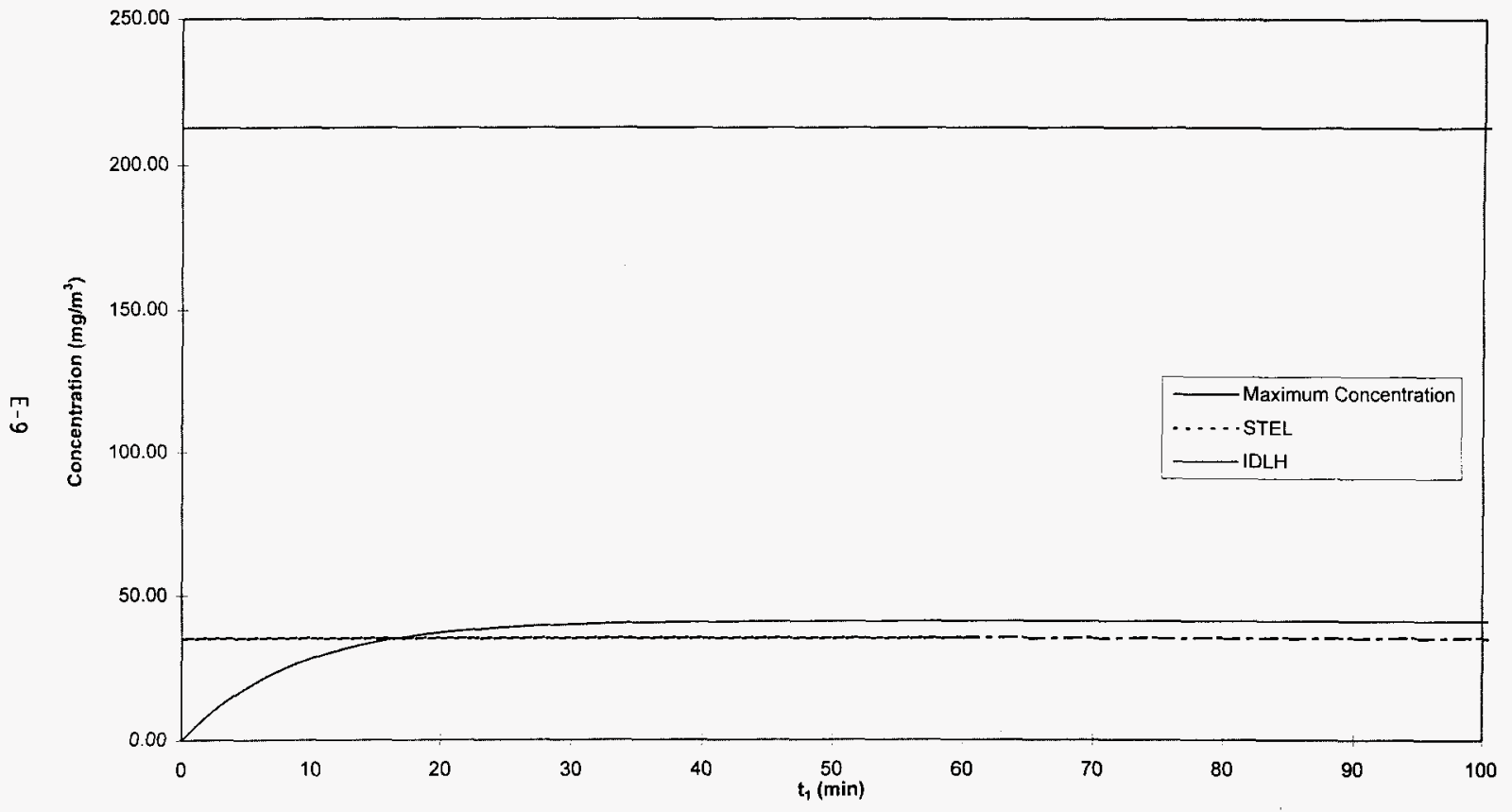

(1) Maximum concentration is that concentration seen at time $t$, if the chemical is placed in a hood at time $t$.

(2) Average concentration is cumulative average concentration if the chemical is placed in a hood at time $t$, and the person remains in the area for 4

hours.

(3) Exposure limit is the most restrictive from OSHA or ACGIH. 
HNF-SD-SUP-LB-001, Rev. 0

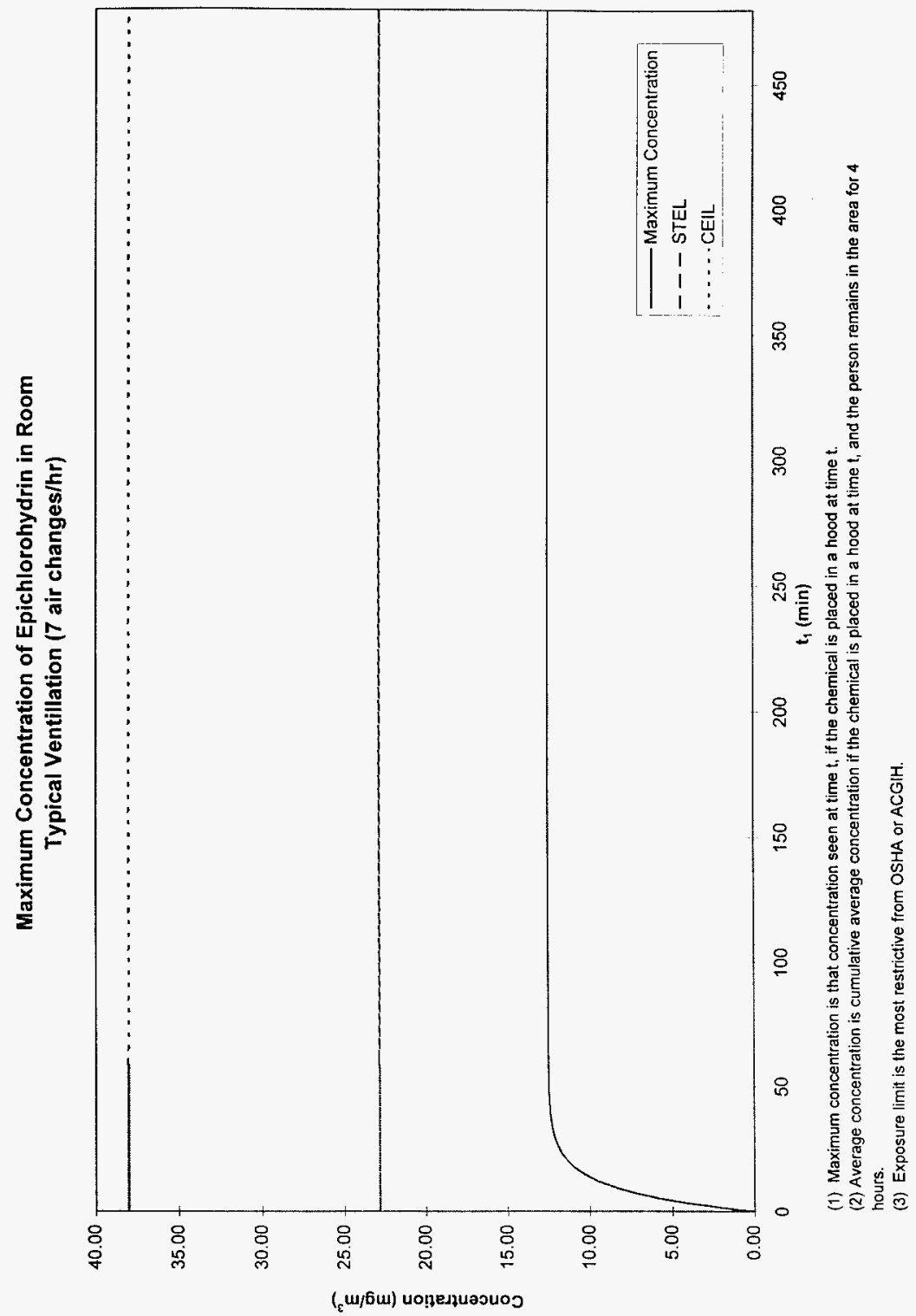

$E-10$ 
HNF-SD-SUP-LB-001, Rev. 0

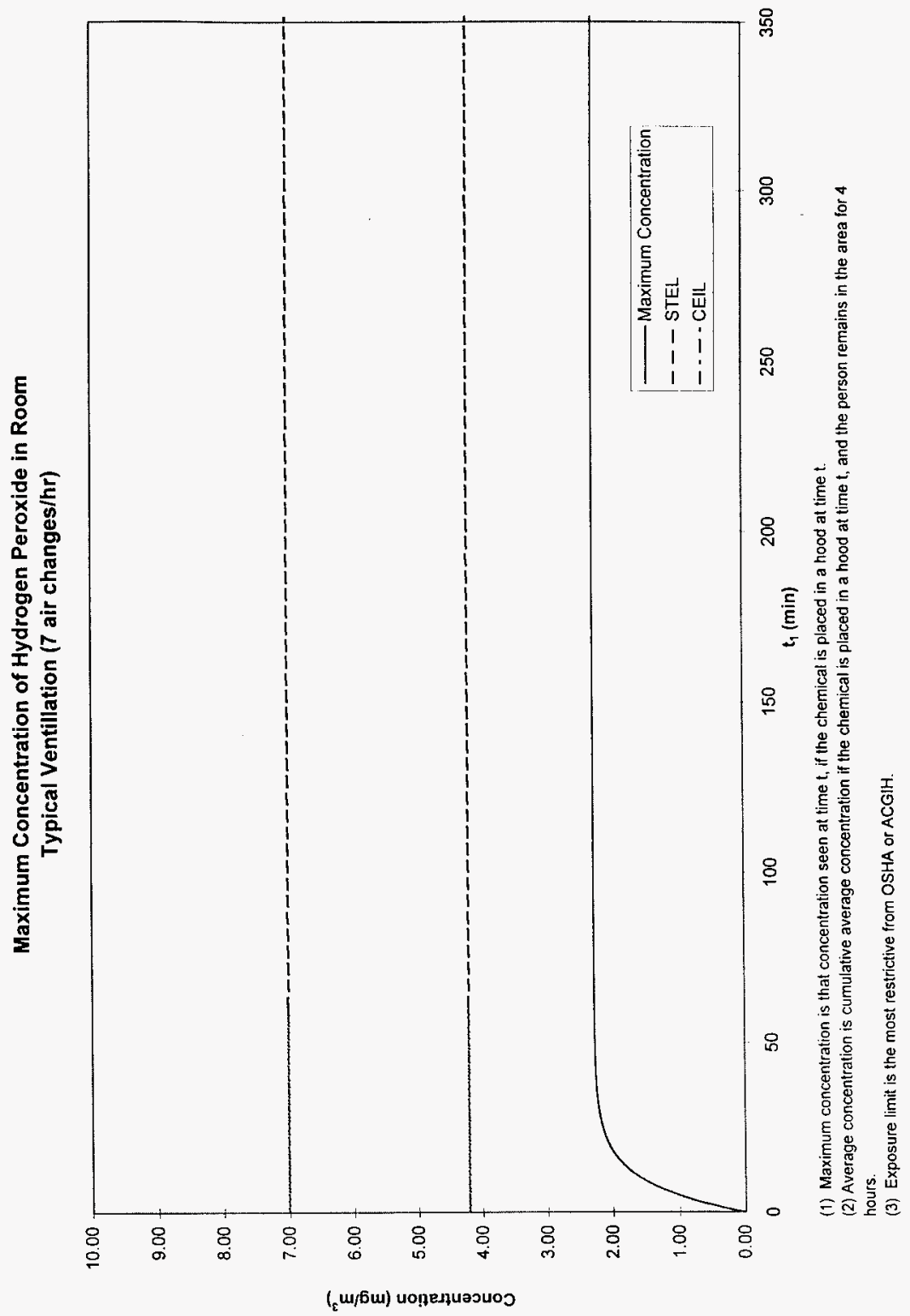




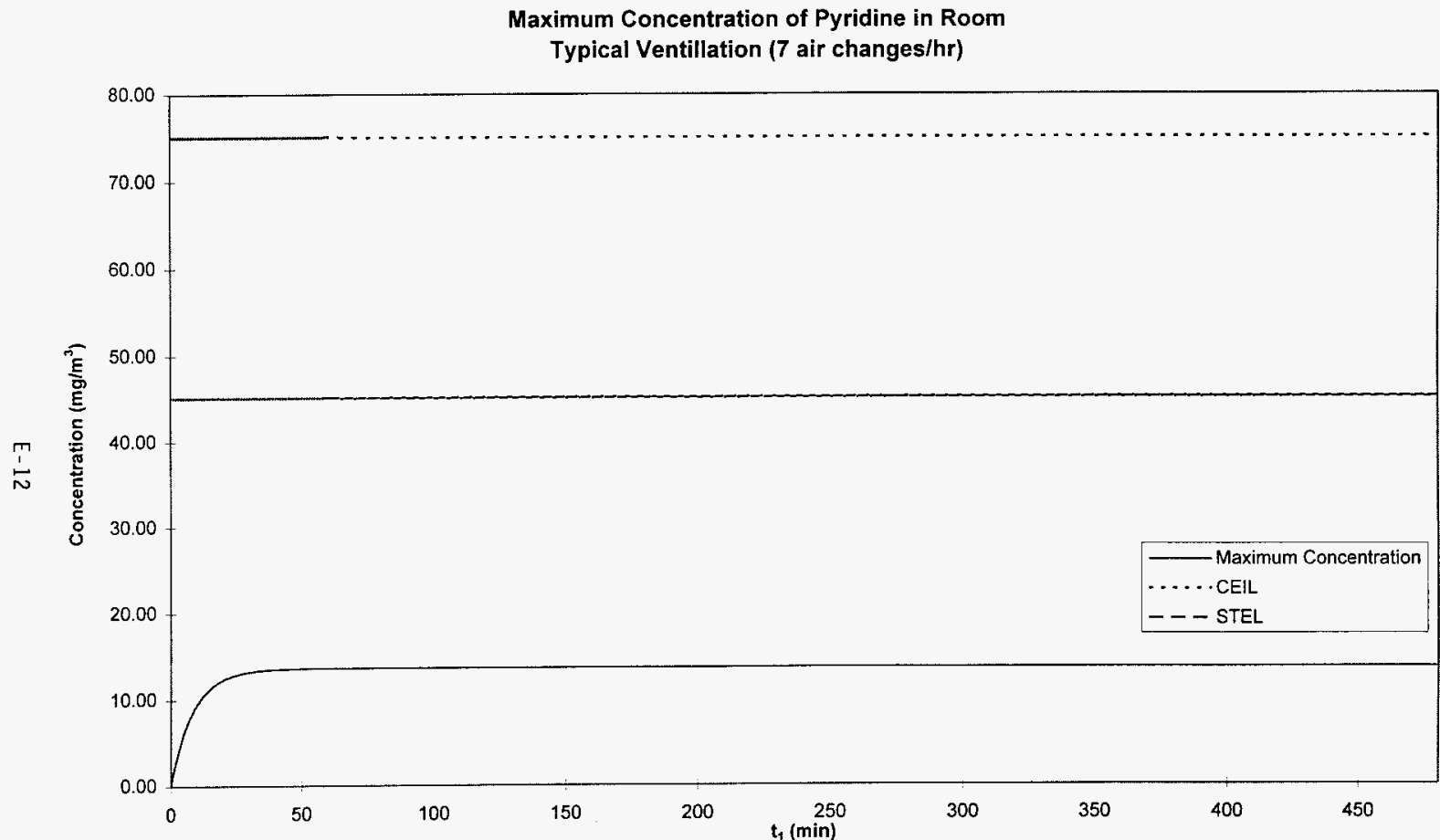

(1) Maximum concentration is that concentration seen at time t, if the chemical is placed in a hood at time t

(2) Average concentration is cumulative average concentration if the chemical is placed in a hood at time $t$, and the person remains in the area for 4 hours.

(3) Exposure limit is the most restrictive from OSHA or ACGIH 


\section{Maximum Concentration of $\mathbf{n}$-Hexane in Room}

Typical Ventillation (7 air changes/hr)

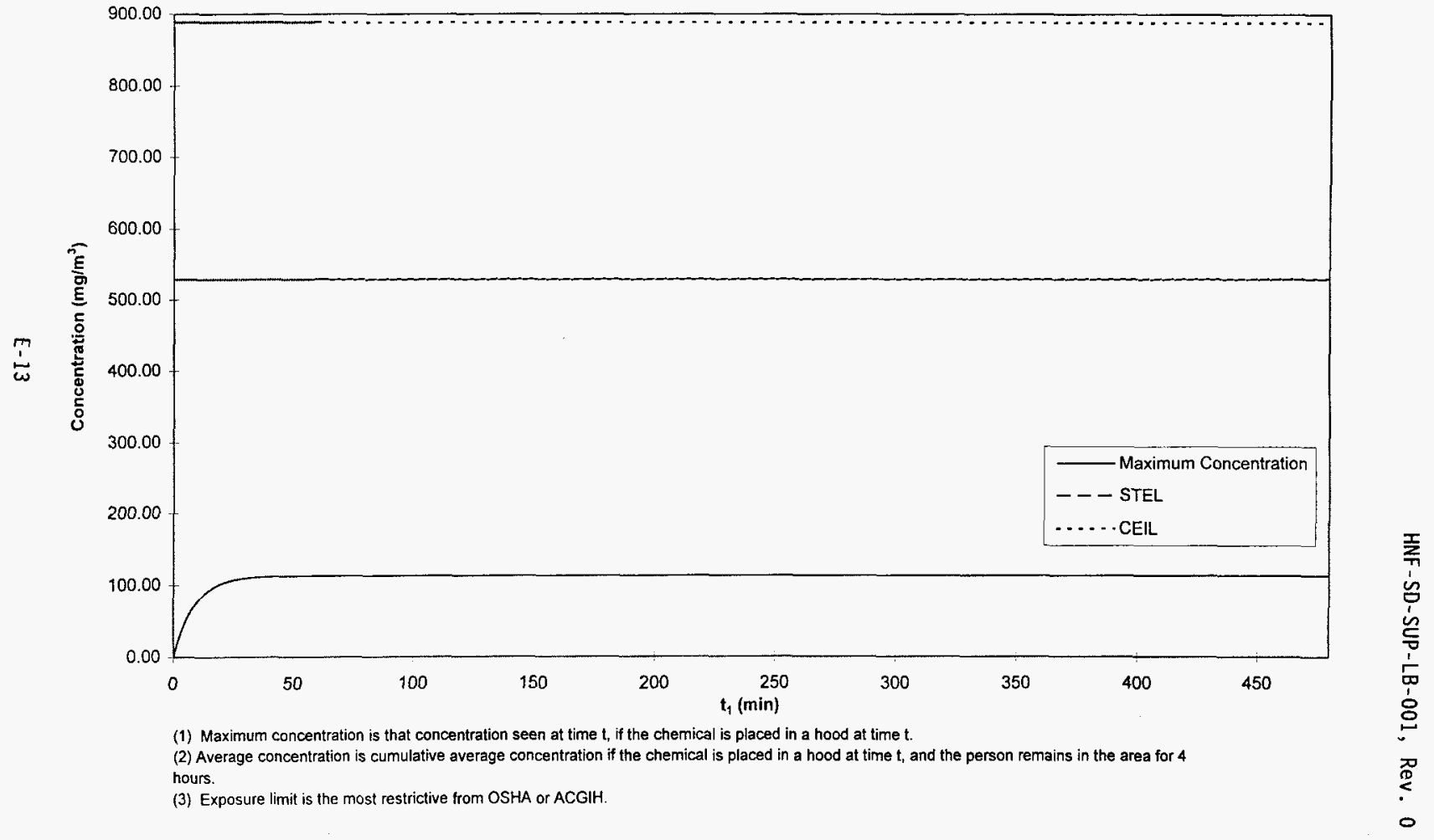


HNF-SD-SUP-LB-001, Rev. 0

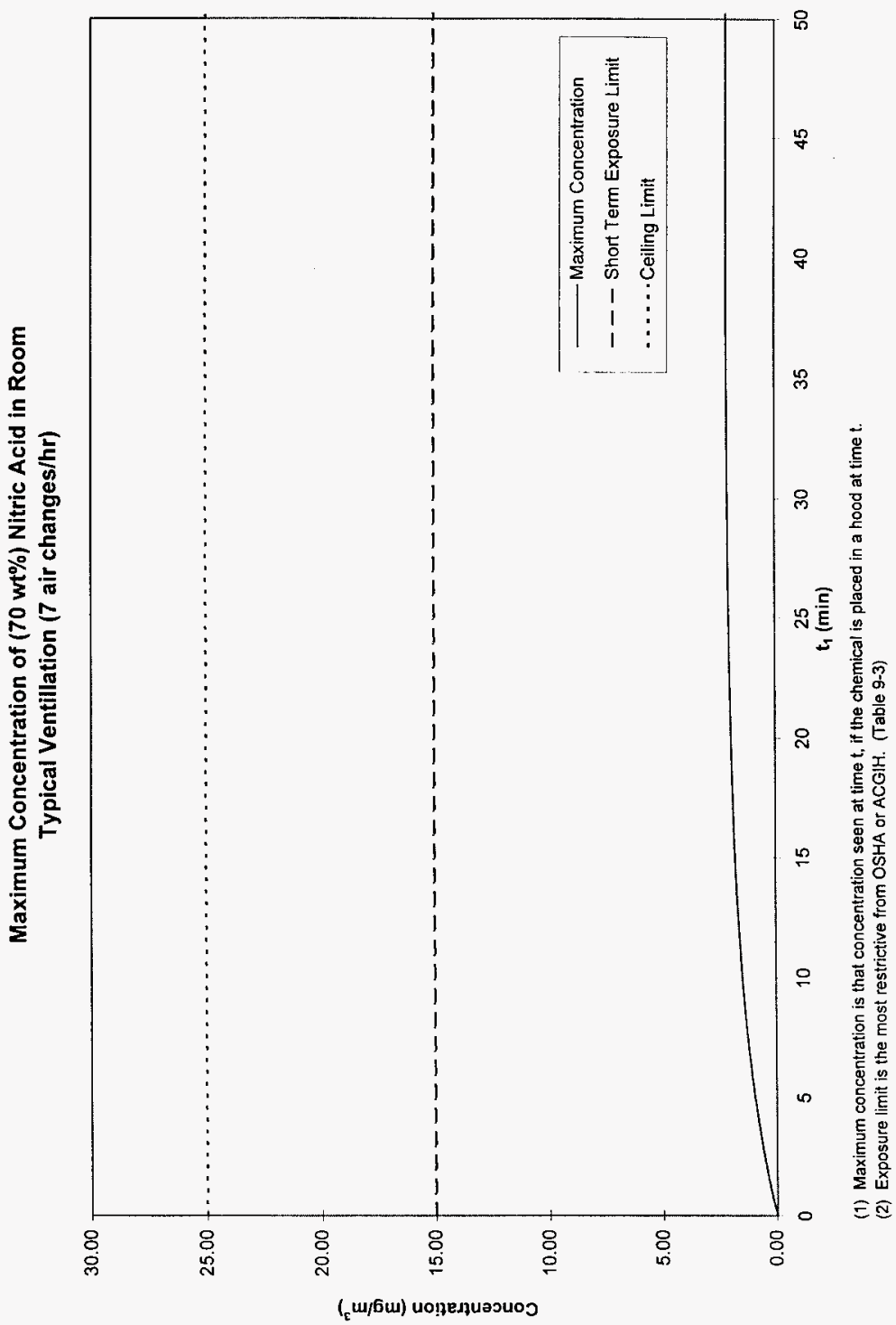


Maximum Concentration of Insta Gel in Room

Typical Ventillation (7 air changes/hr)

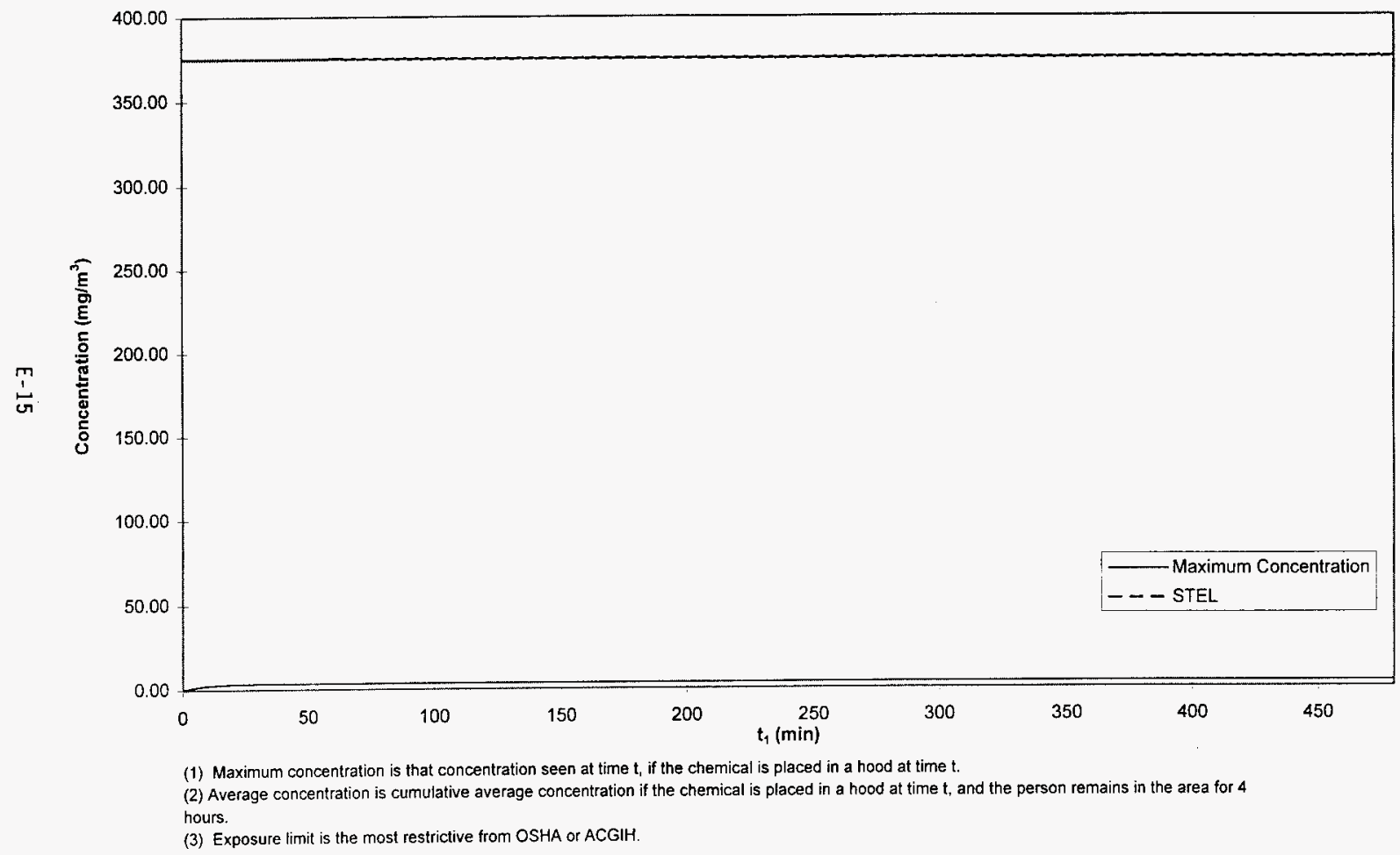




\section{Maximum Concentration of Ethyl Alcohol in Room}

Typical Ventillation (7 air changes/hr)

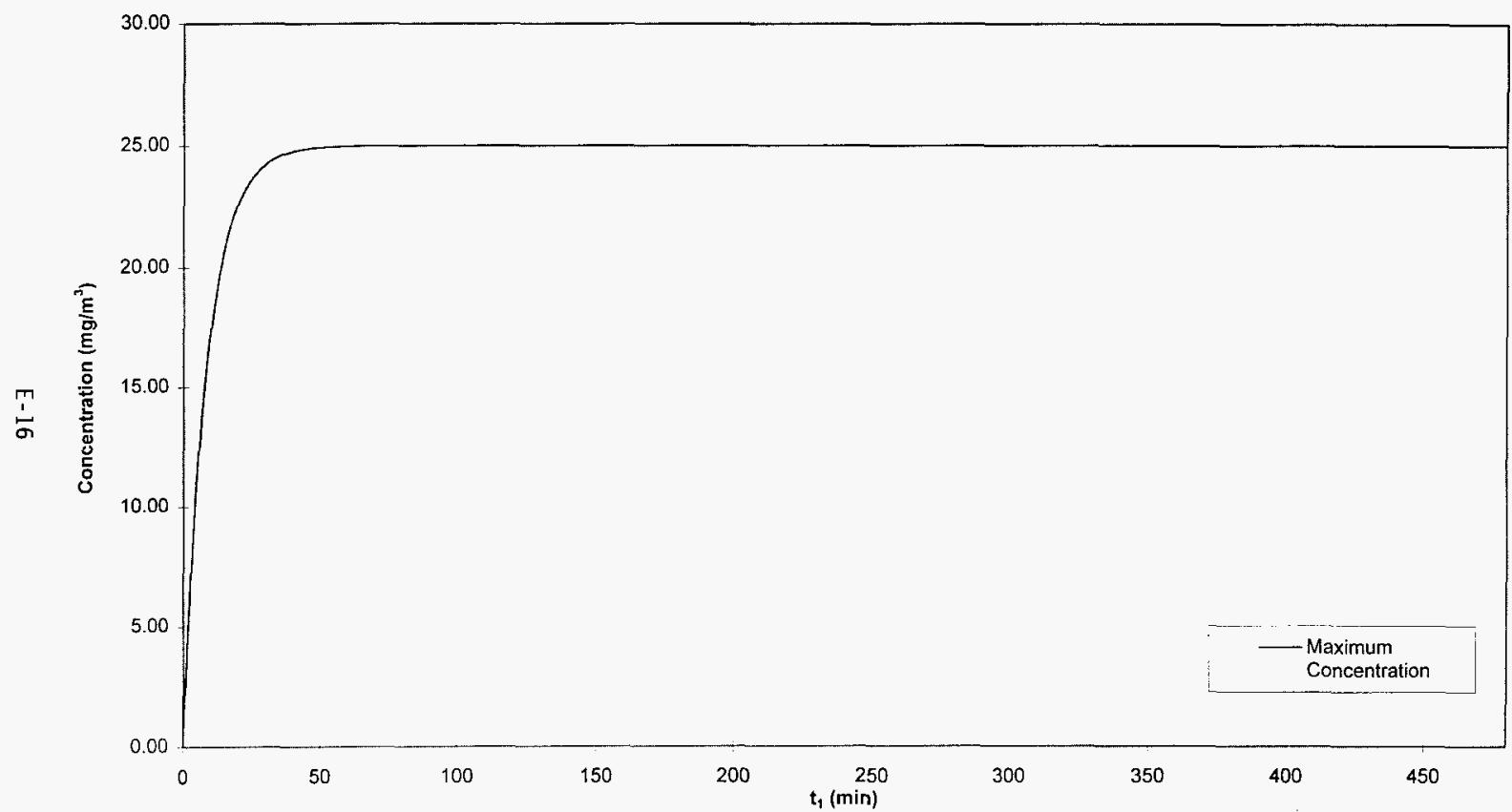

(1) Maximum concentration is that concentration seen at time $t$, if the chemical is placed in a hood at time $t$.

(2) Average concentration is cumulative average concentration if the chemical is placed in a hood at time $t$, and the person remains in the area for 4 hours.

(3) Exposure limit is the most restrictive from OSHA or ACGIH. 
HNF-SD-SUP-LB-001, Rev. 0

APPENDIX F

AVERAGE AIRBORNE CONCENTRATIONS UNDER TYPICAL VENTILATION CONDITIONS

$F-1$ 
HNF-SD-SUP-LB-001, Rev. 0

This page intentionally left blank. 


\section{Averaged Concentration of Hydrochloric Acid in Room \\ Typical Ventillation (7 air changes/hr)}

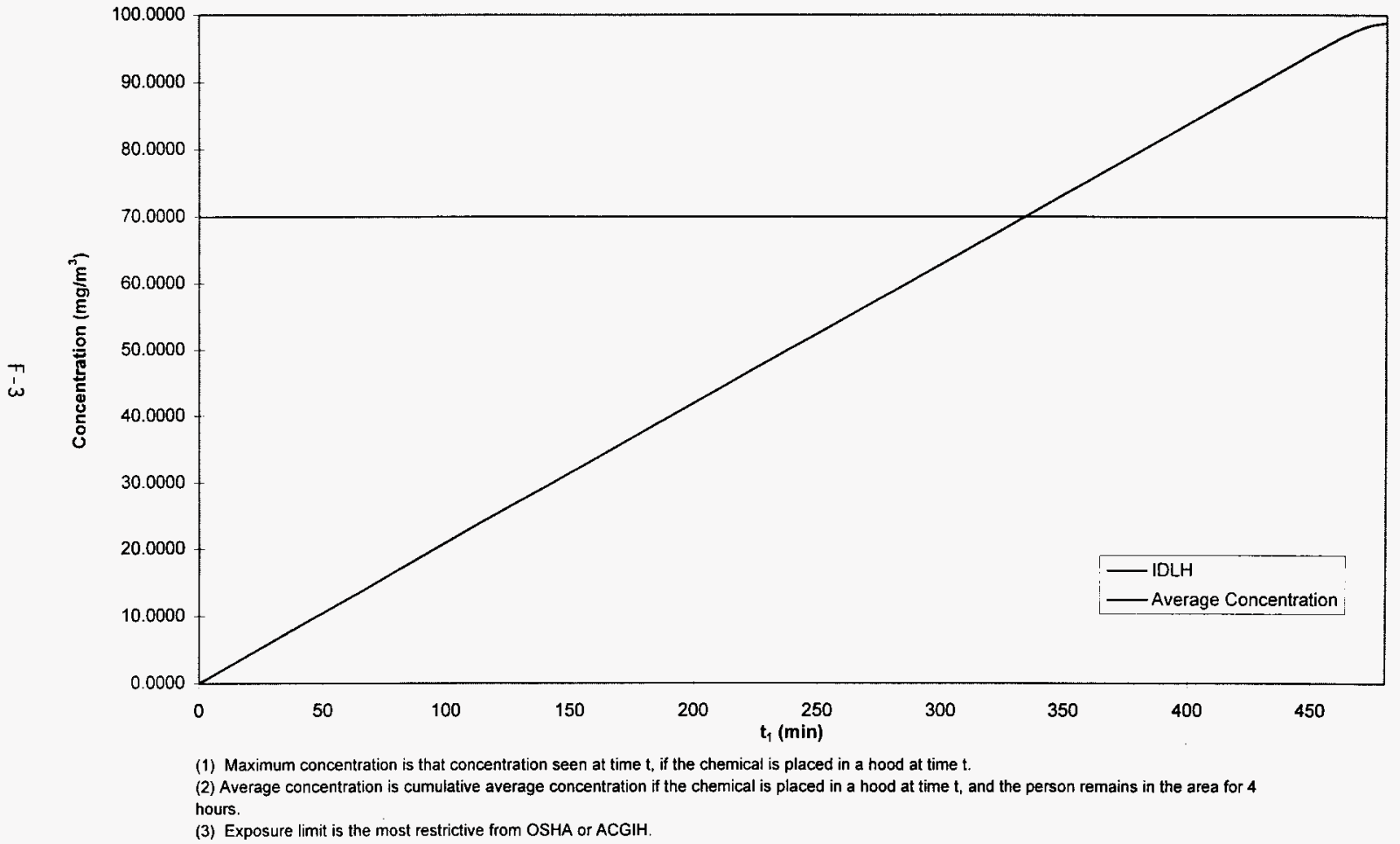




\section{Averaged Concentration of Methylene Chloride in Room \\ Typical Ventillation (7 air changes/hr)}

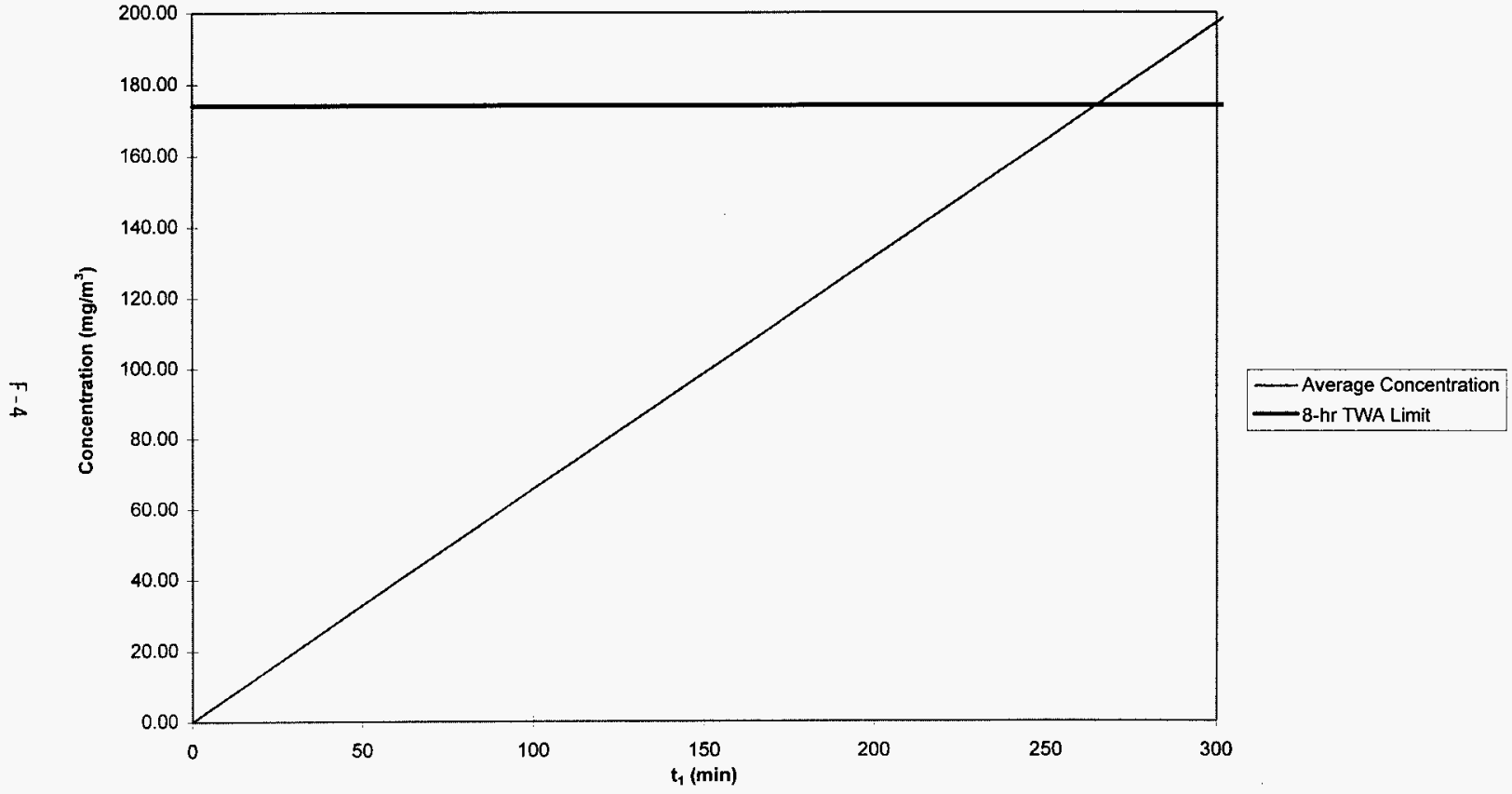

(1) Maximum concentration is that concentration seen at time $t$, if the chemical is placed in a hood at time t.

(2) Average concentration is cumulative average concentration if the chemical is placed in a hood at time $t$, and the person remains in the area for 4 hours.

(3) Exposure limit is the most restrictive from OSHA or ACGIH. 


\section{Averaged Concentration of Bromine in Room}

Typical Ventillation (7 air changes/hr)

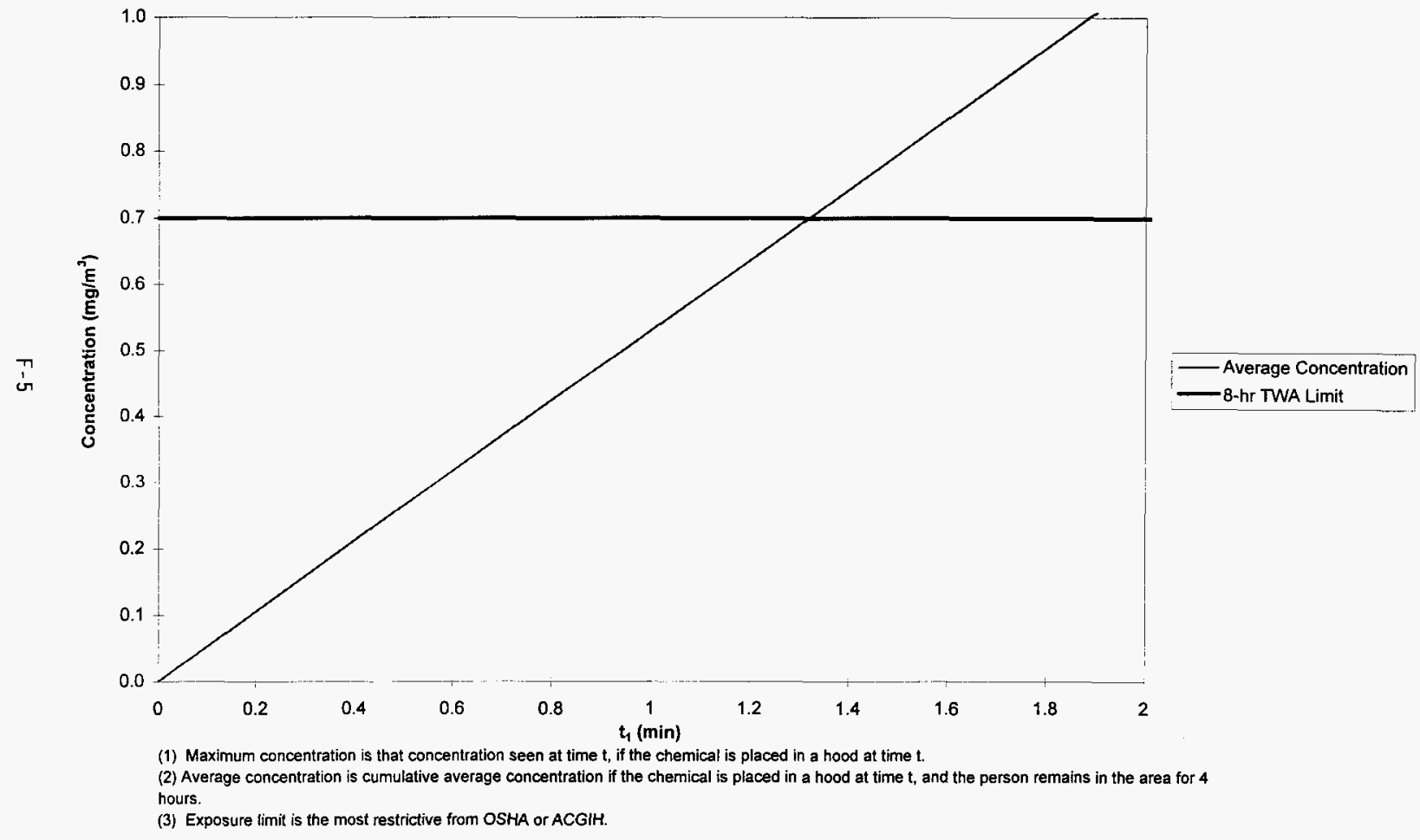




\section{Averaged Concentration of Benzene in Room}

Typical Ventillation (7 air changes/hr)

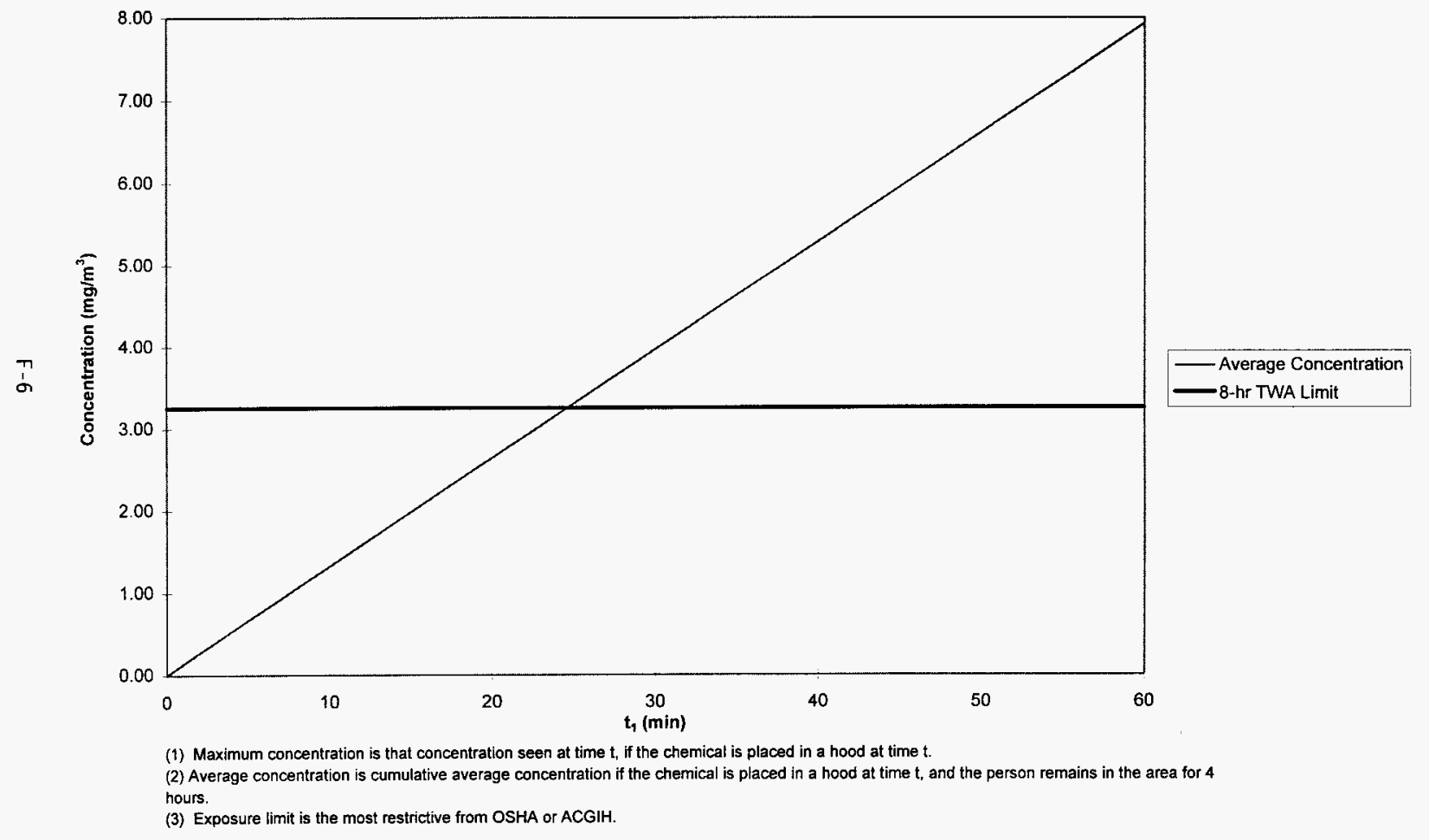


Averaged Concentration of $27 \mathrm{Wt} \%$ Ammonium Hydroxide (as Ammonia) in Room Typical Ventillation (7 air changes/hr)

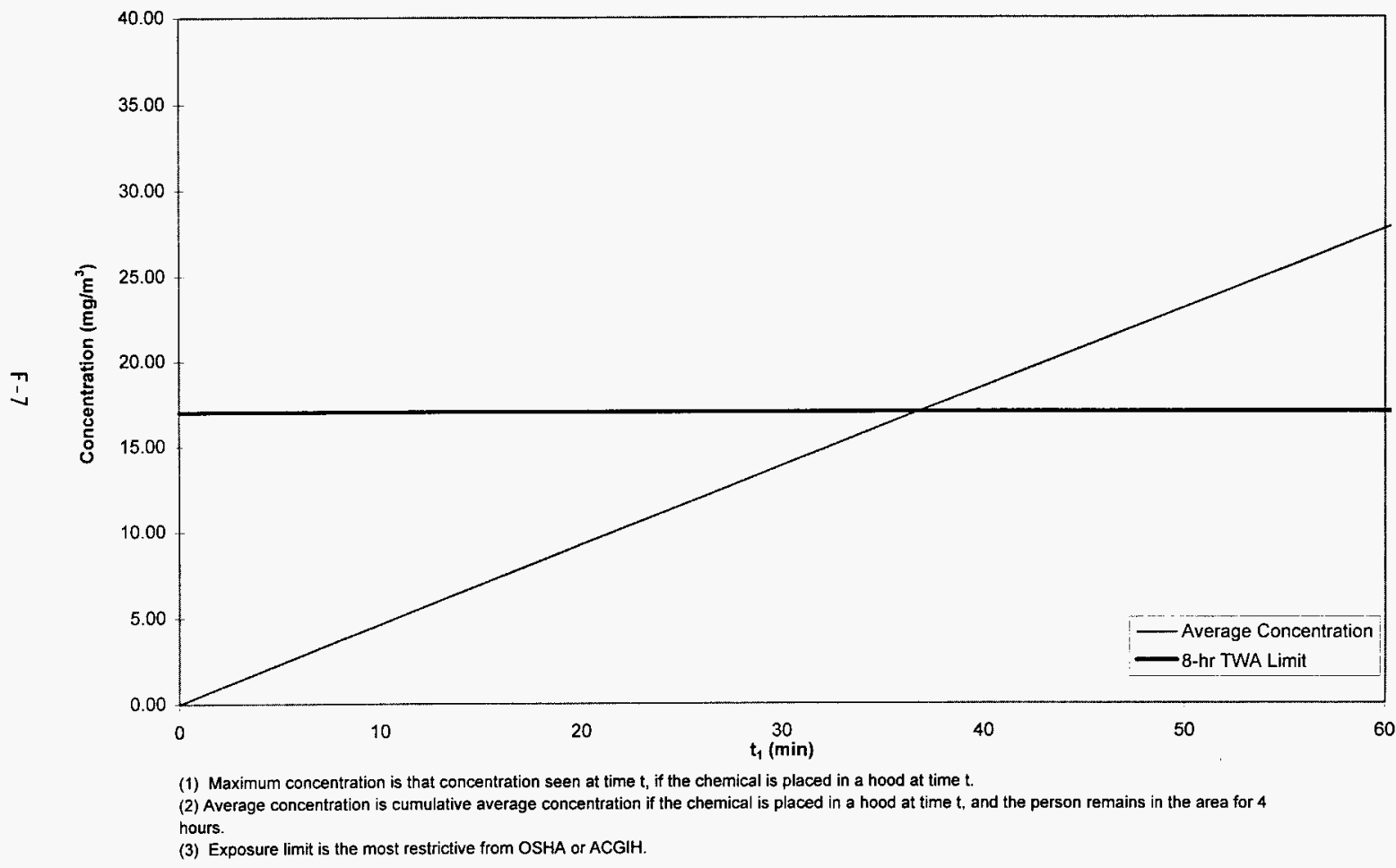




\section{Averaged Concentration of Hydrofluoric Acid in Room}

Typical Ventillation (7 air changes/hr)

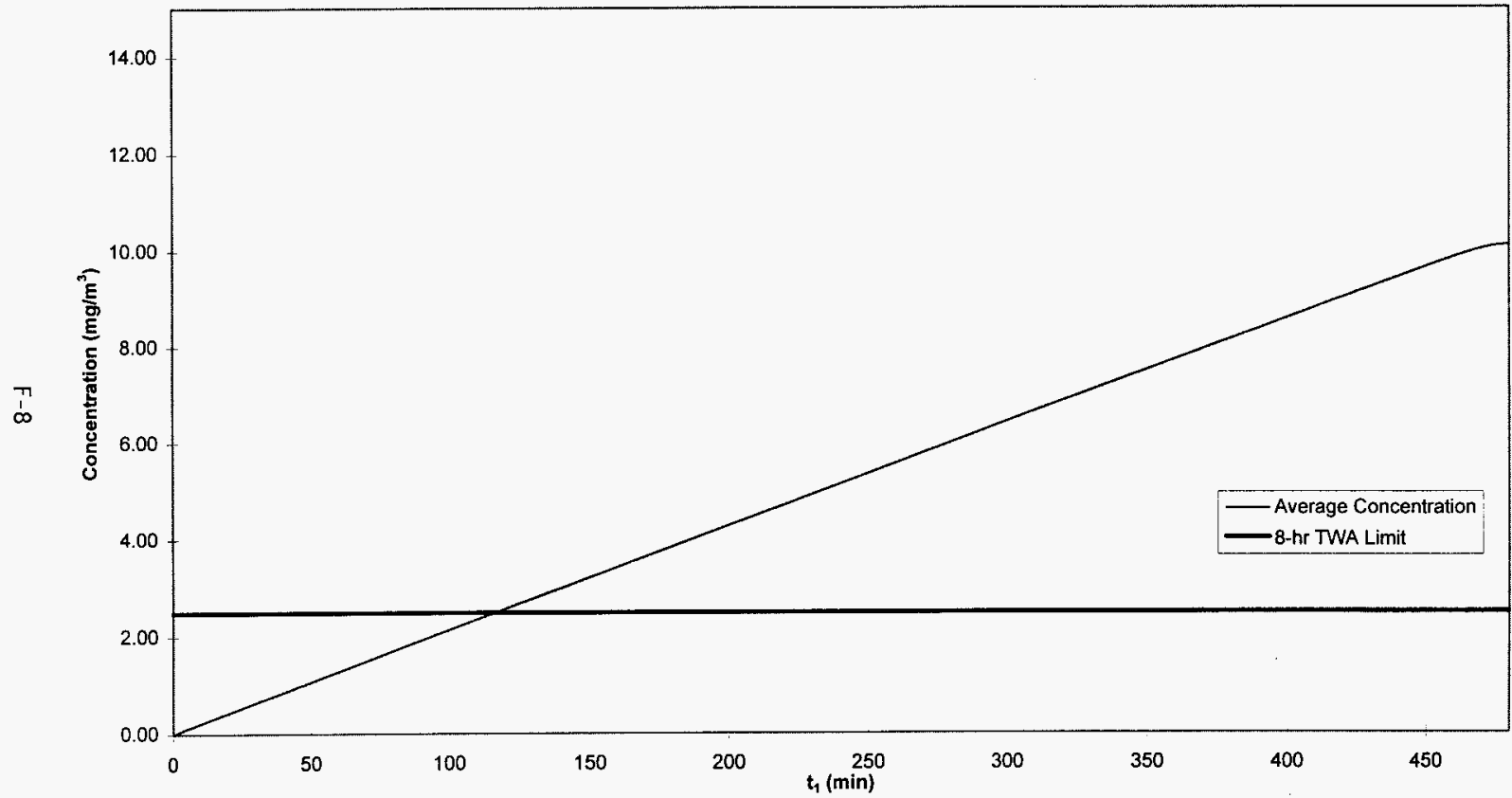

(1) Maximum concentration is that concentration seen at time $t$, if the chemical is placed in a hood at time $t$.

(2) Average concentration is cumulative average concentration if the chemical is placed in a hood at time $t$, and the person remains in the area for 4

(3) Exposure limit is the most restrictive from OSHA or ACGIH 


\section{Averaged Concentration of $11 \mathrm{Wt} \%$ Ammonium Hydroxide (as Ammonia) in Room}

Typical Ventillation (7 air changes/hr)

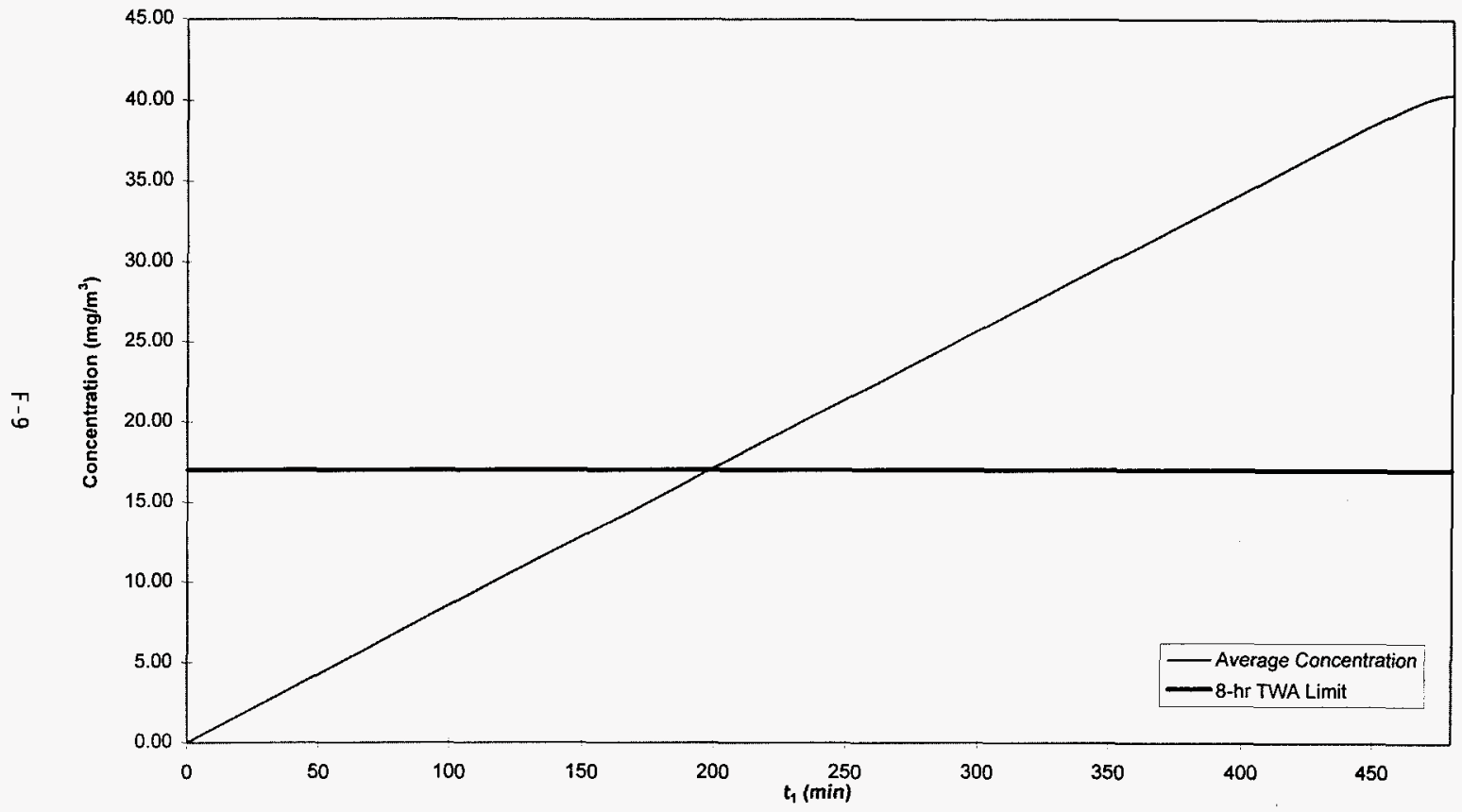

(1) Maximum concentration is that concentration seen at time $t$, if the chemical is placed in a hood at time $t$.

(2) Average concentration is cumulative average concentration if the chemical is placed in a hood at time $t$, and the person remains in the area for 4

hours.

(3) Exposure limit is the most restrictive from OSHA or ACGIH. 


\section{Averaged Concentration of Epichlorohydrin in Room}

Typical Ventillation ( 7 air changes/hr)

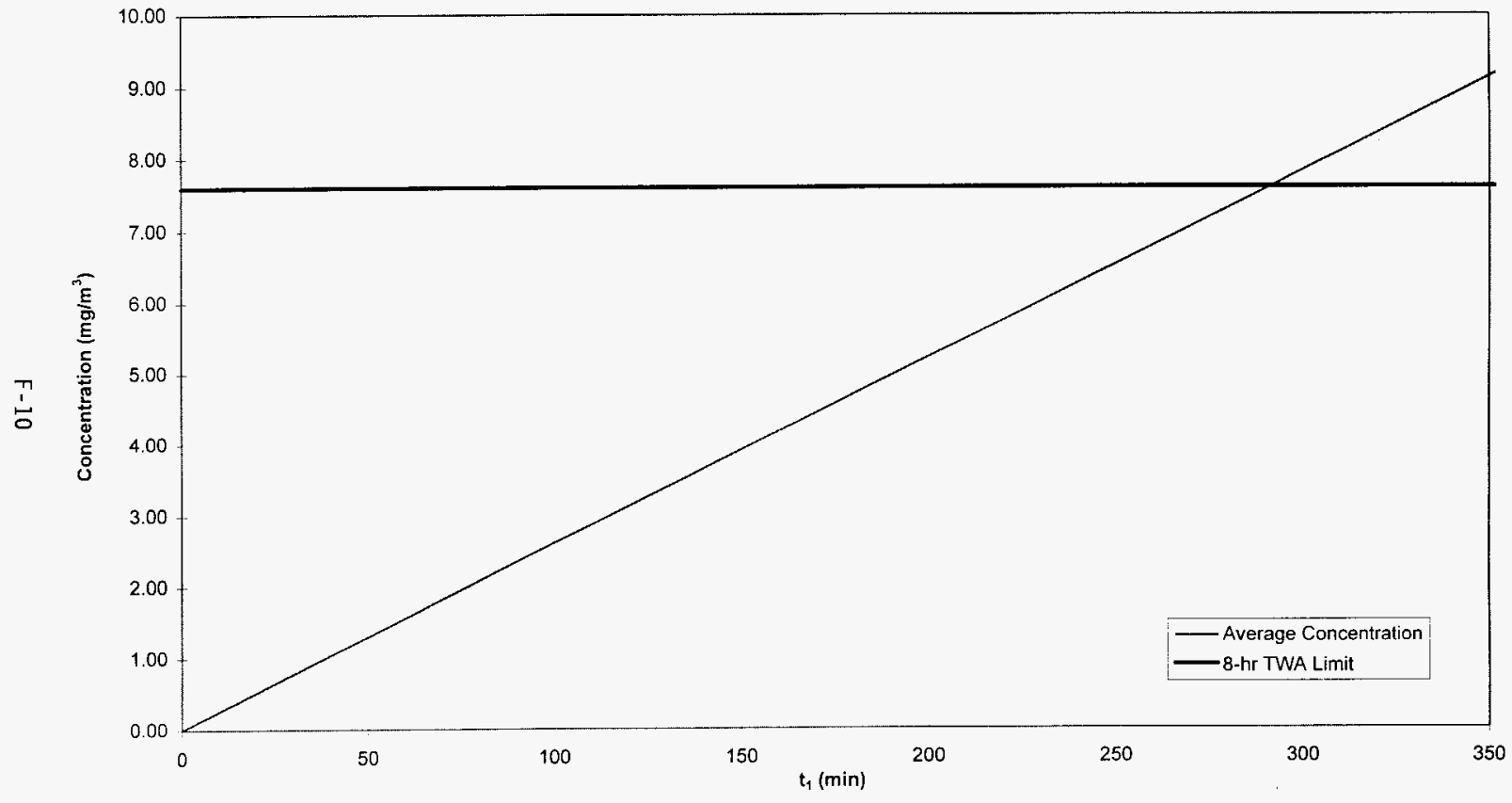

(1) Maximum concentration is that concentration seen at time $t$, if the chemical is placed in a hood at time $t$.

(2) Average concentration is cumulative average concentration if the chemical is placed in a hood at time $t$, and the person remains in the area for 4

hours.

(3) Exposure limit is the most restrictive from OSHA or ACGIH 


\section{Averaged Concentration of Hydrogen Peroxide in Room}

Typical Ventillation (7 air changes/hr)

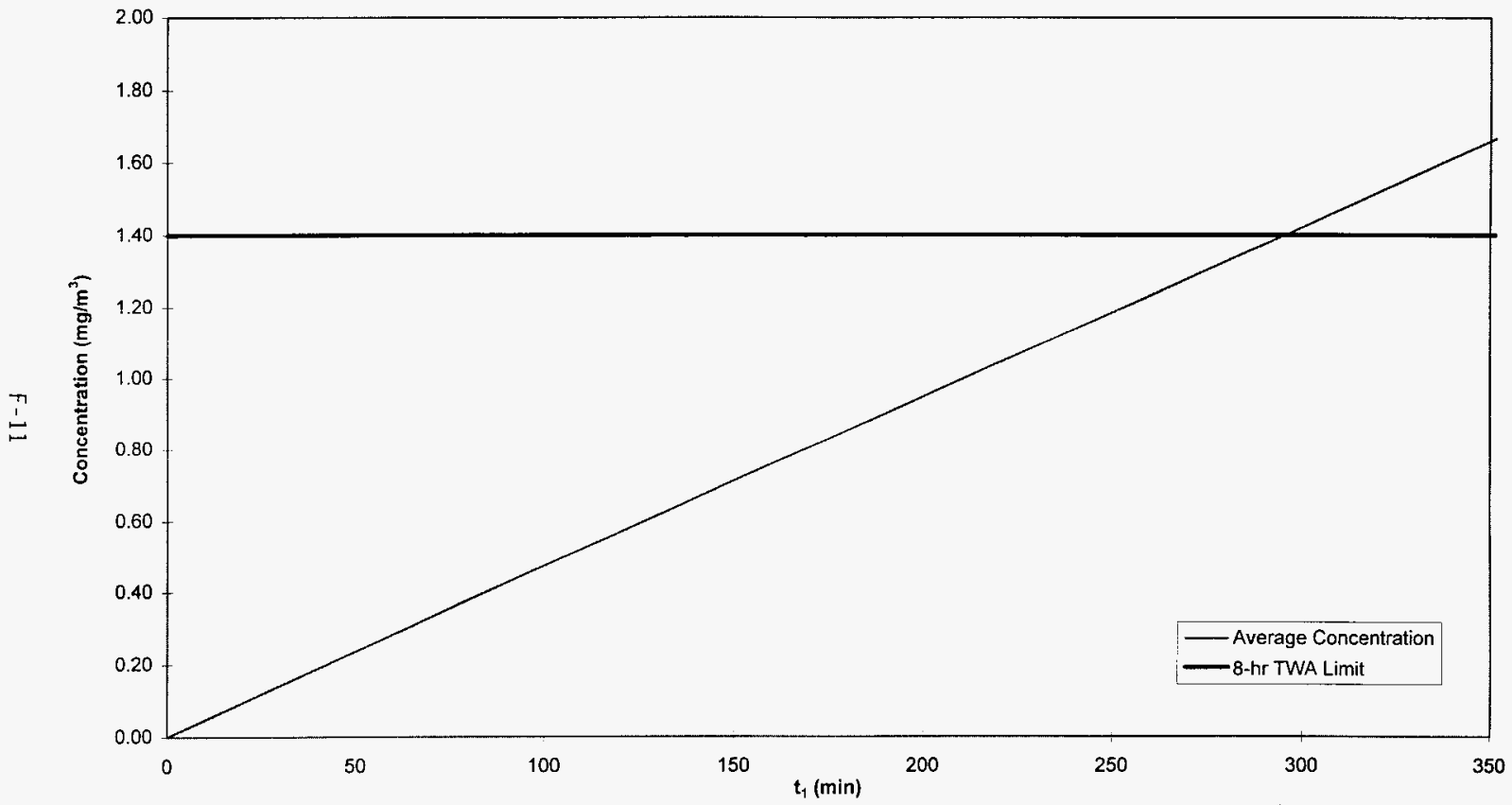

(1) Maximum concentration is that concentration seen at time $t$, if the chemical is placed in a hood at time t.

(2) Average concentration is cumulative average concentration if the chemical is placed in a hood at time $t$, and the person remains in the area for 4

hours.

(3) Exposure limit is the most restrictive from OSHA or ACGIH. 
Averaged Concentration of Pyridine in Room

Typical Ventillation (7 air changes/hr)

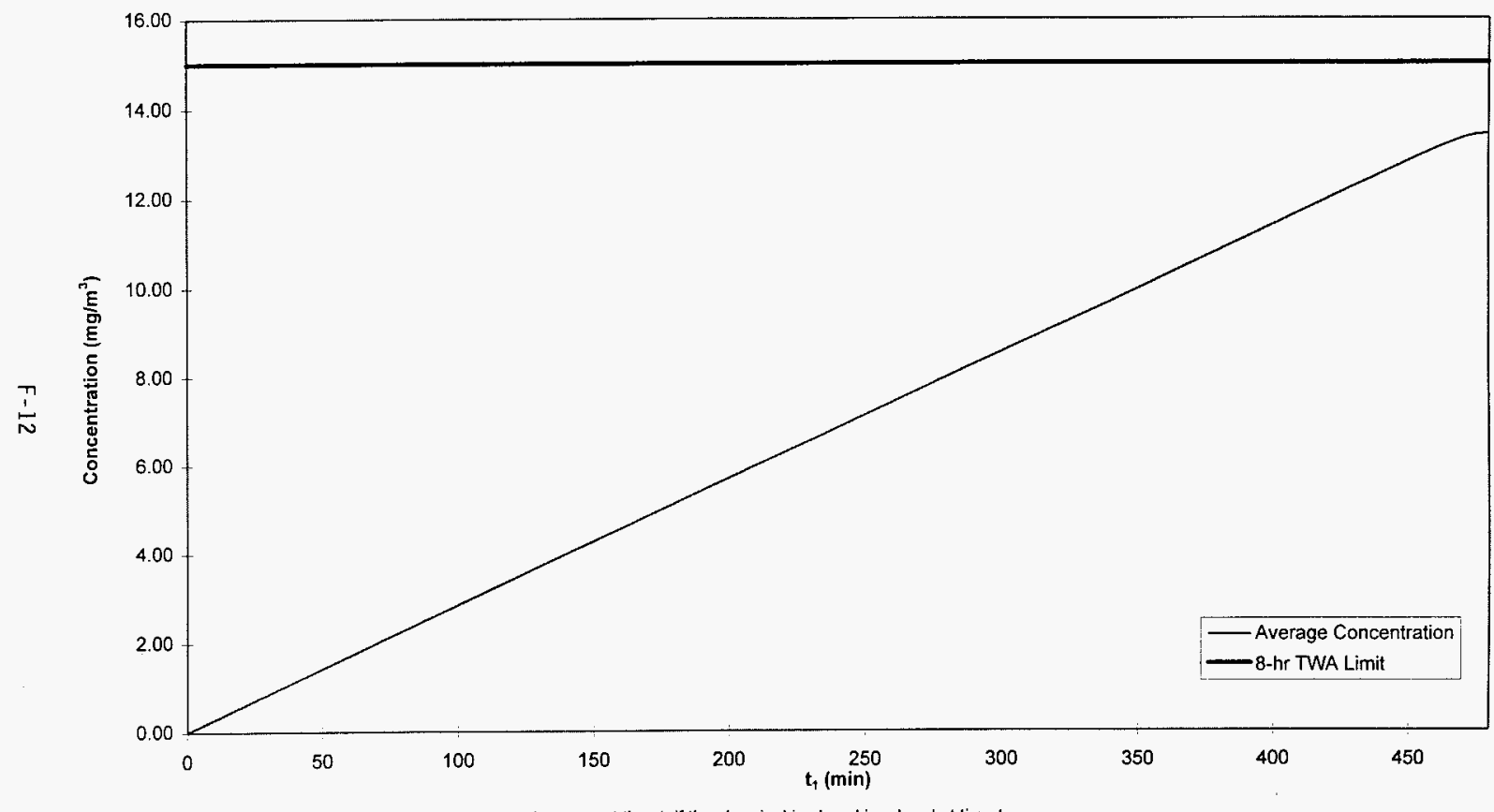

(1) Maximum concentration is that concentration seen at time $t$, it the chemical is placed in a hood at time $t$.

(2) Average concentration is cumulative average concentration if the chemical is placed in a hood at time $t$, and the person remains in the area for 4

hours.

(3) Exposure limit is the most restrictive from OSHA or ACGIH 


\section{Averaged Concentration of $\boldsymbol{n}$-Hexane in Room \\ Typical Ventillation (7 air changes/hr)}

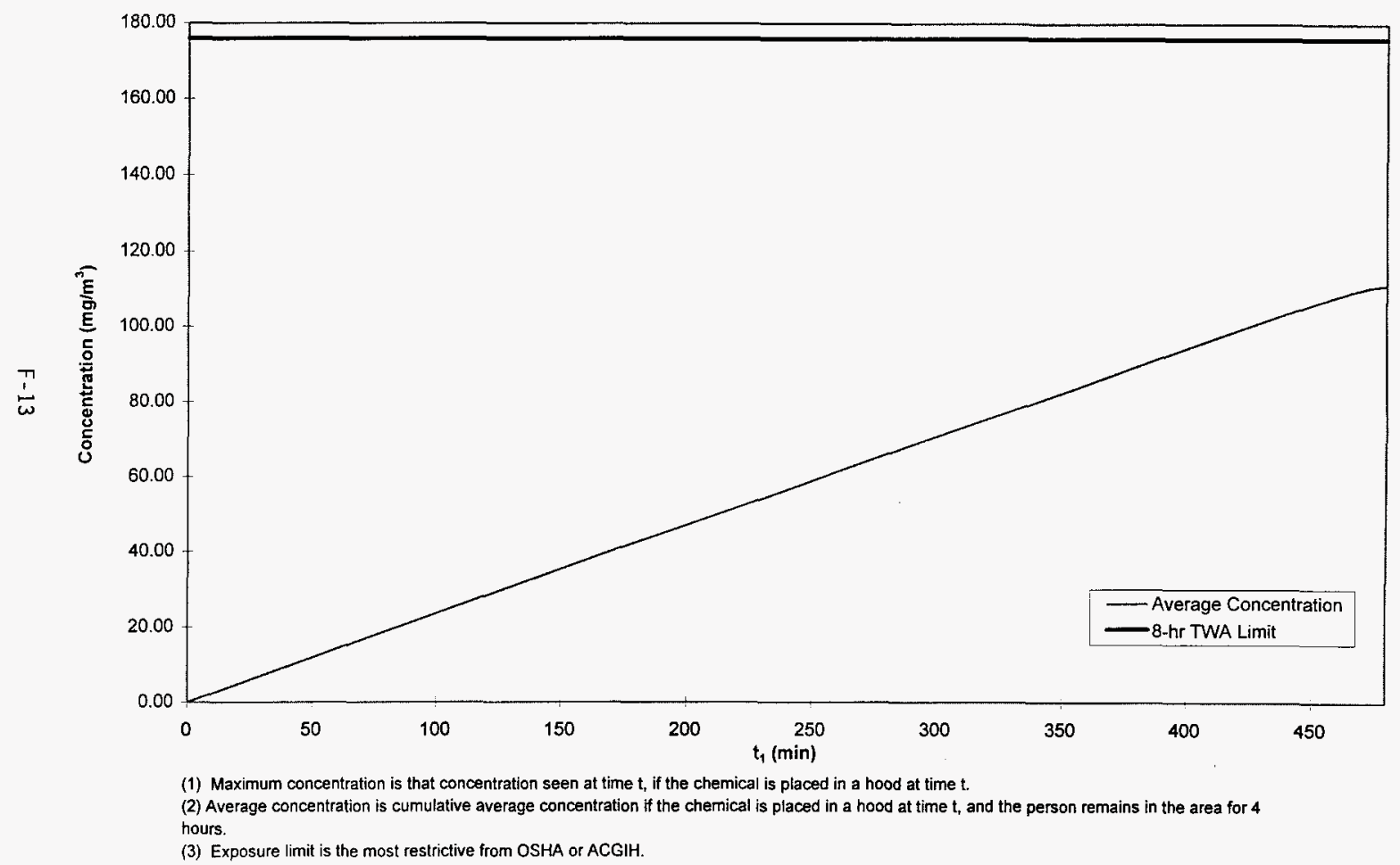


Averaged Concentration of (70 wt\%) Nitric Acid in Room

Typical Ventillation (7 air changes/hr)

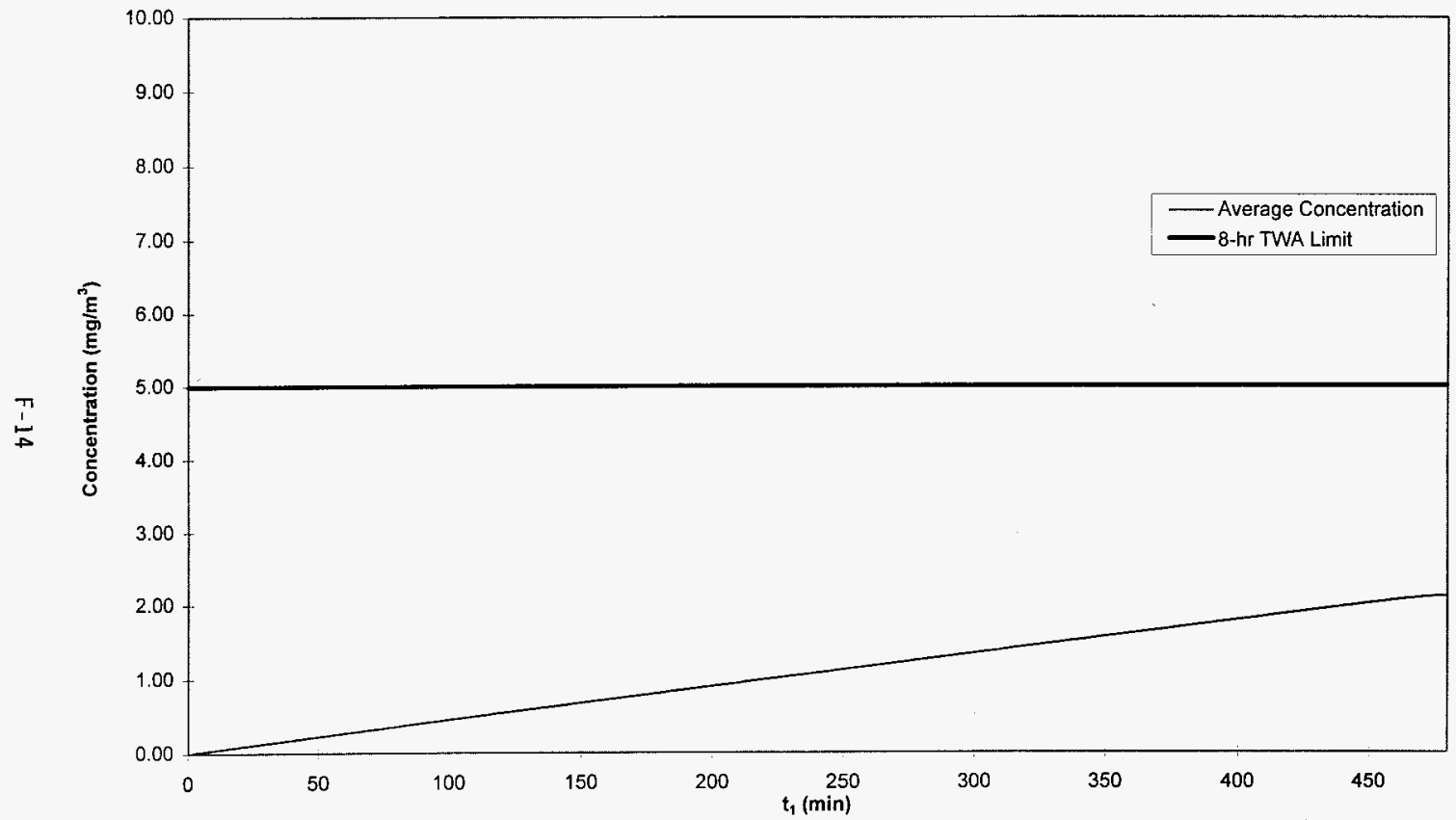

(1) Average concentration is cumulative average concentration if the chemical is placed in a hood at time $t_{r}$ and the person remains in the area for 8 hours.

(2) Exposure limit is the most restrictive from OSHA or ACGIH. (Table 9-3) 


\section{Averaged Concentration of Insta Gel in Room}

Typical Ventillation (7 air changes/hr)

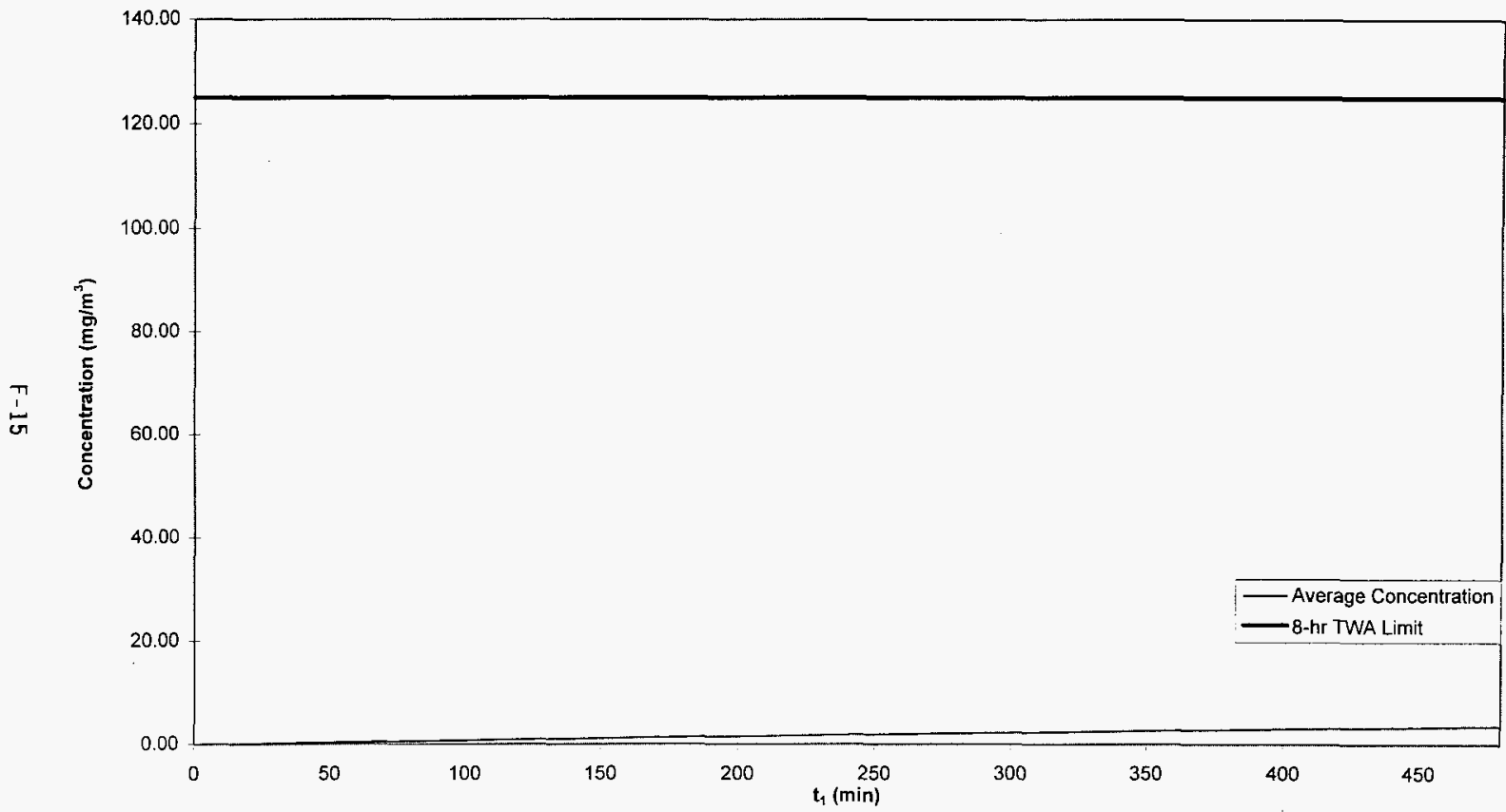

(1) Maximum concentration is that concentration seen at time $t$, if the chemical is placed in a hood at time $t$.

(2) Average concentration is cumulative average concentration if the chemical is placed in a hood at time $t$, and the person remains in the area for 4

hours.

(3) Exposure limit is the most restrictive from OSHA or ACGIH 


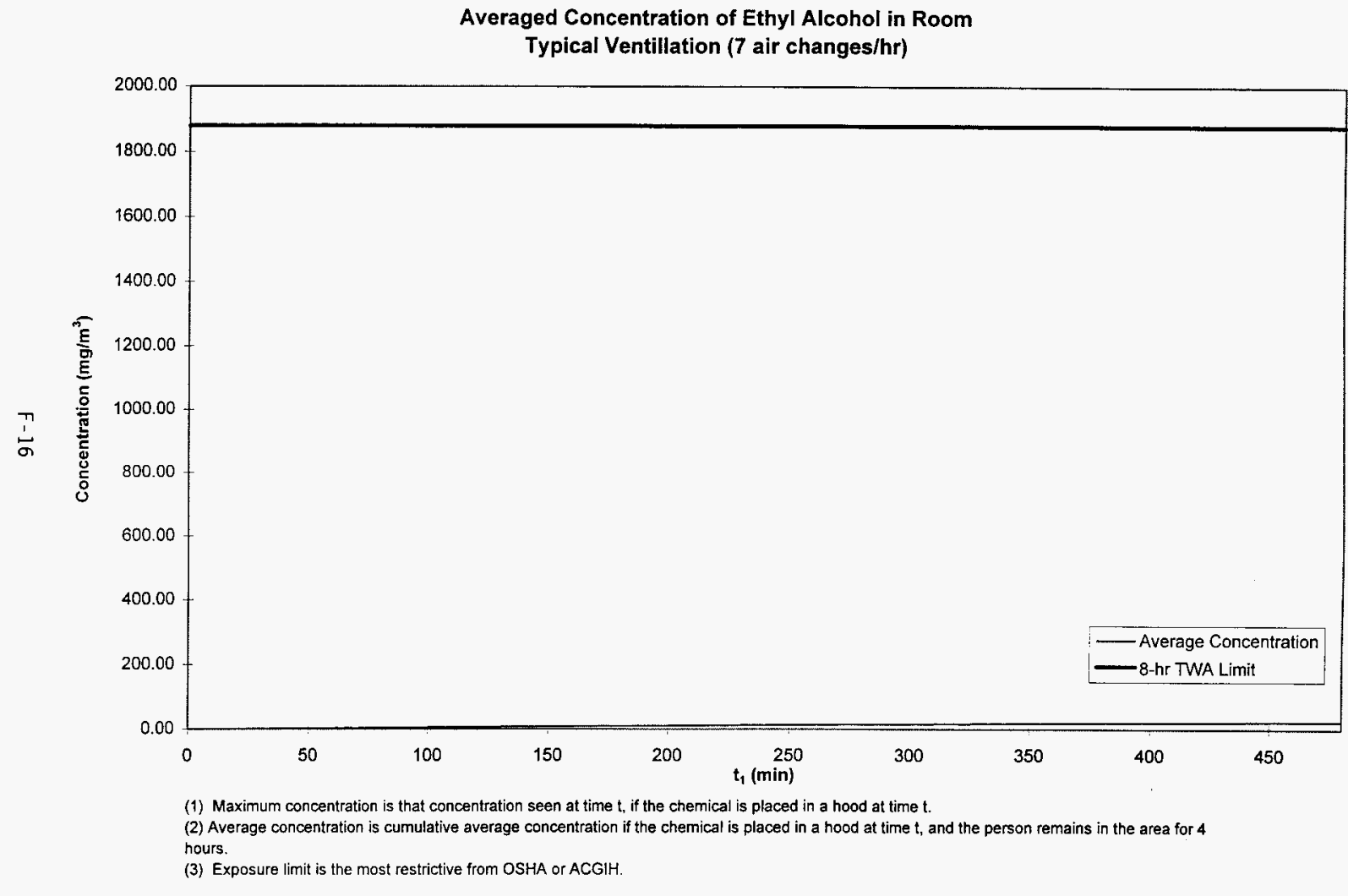

